
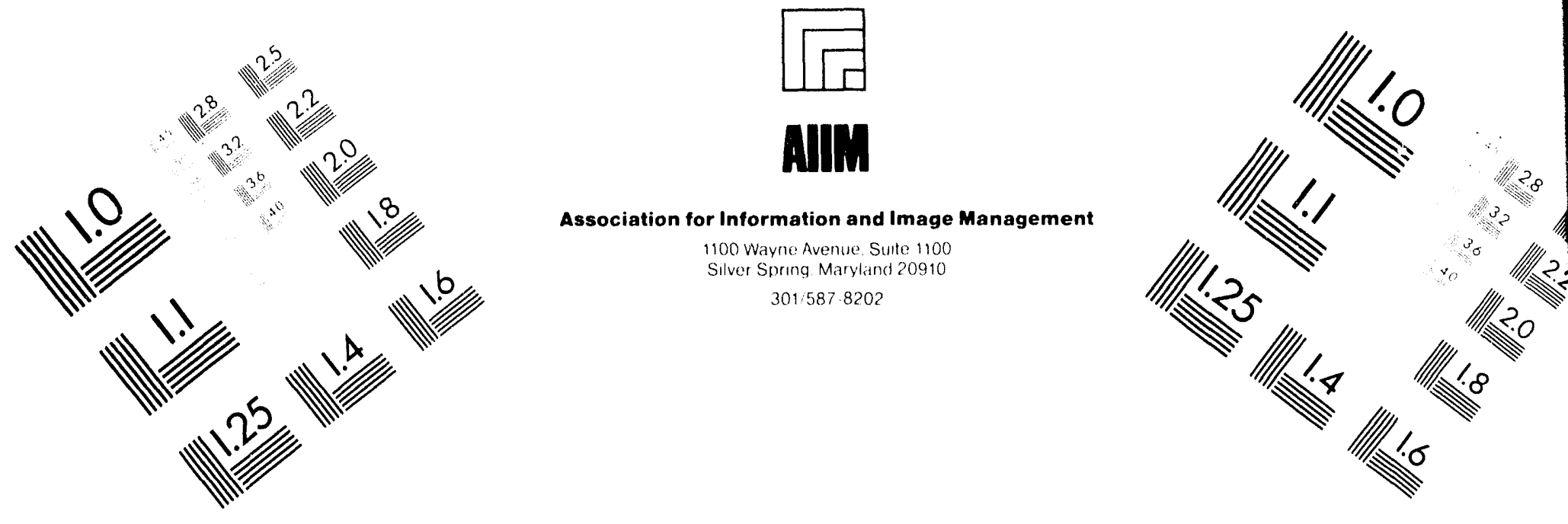

\title{
Centimeter
}

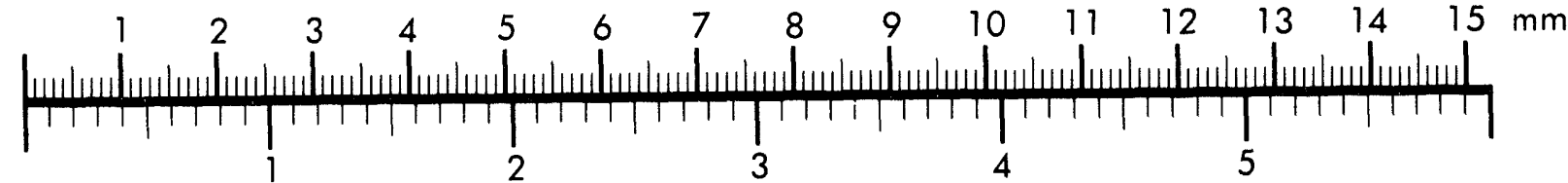

Inches
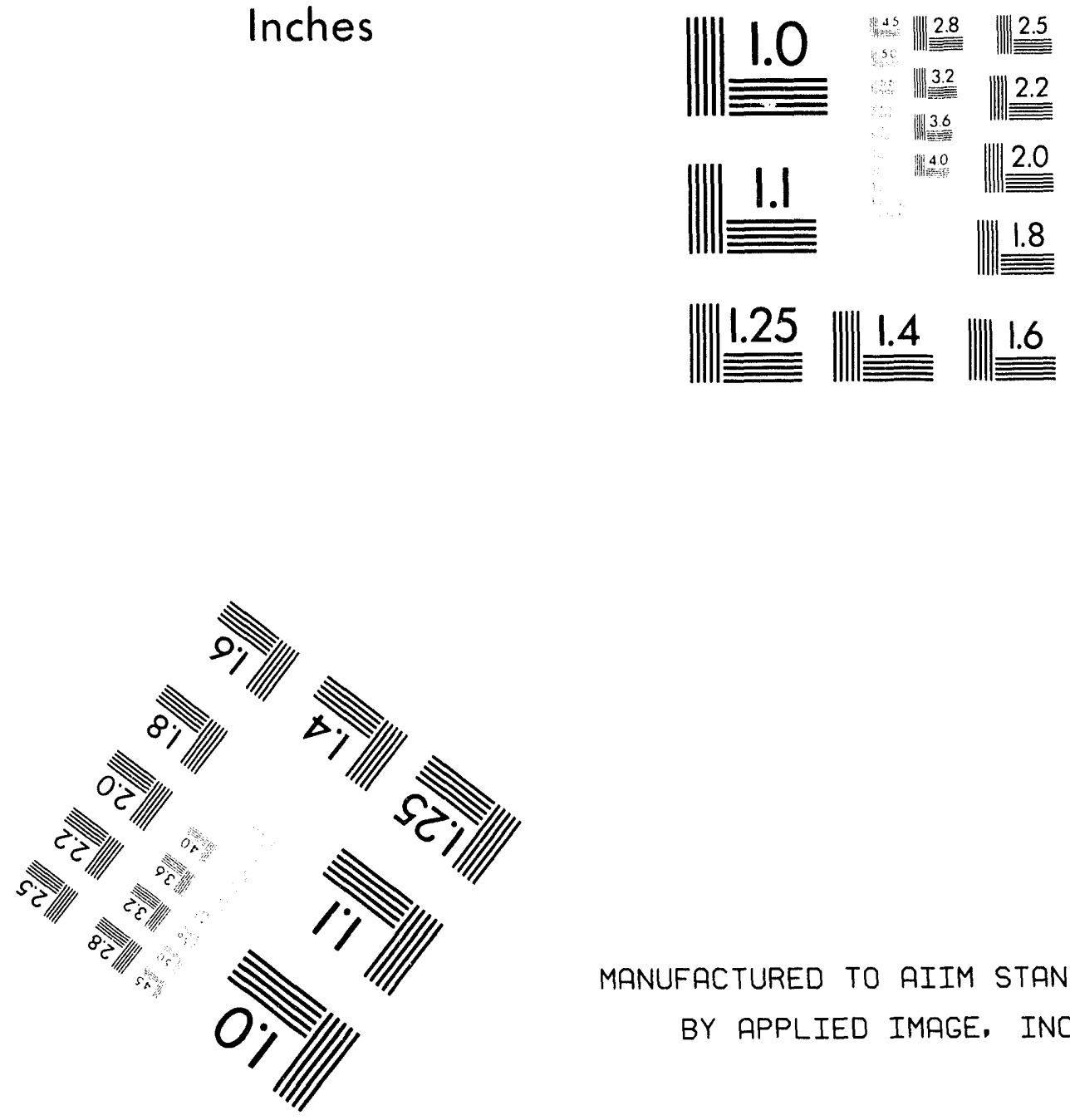

MANUFACTURED TO AIIM STANDARDS

BY APPLIED IMAGE. INC.

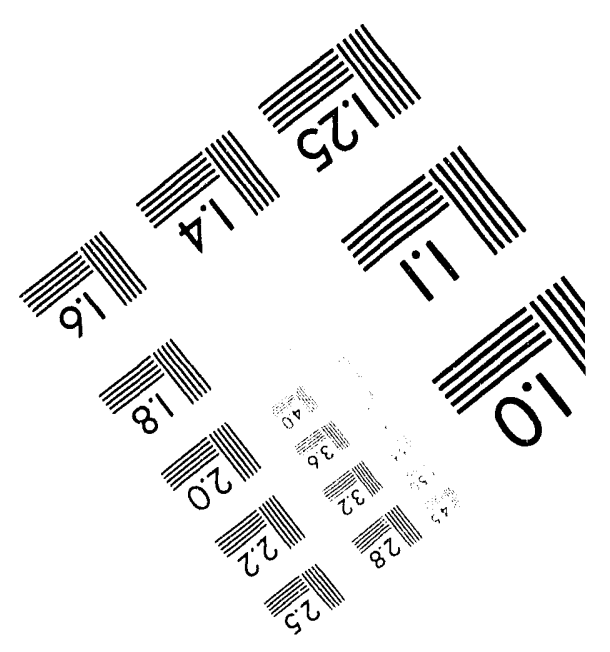



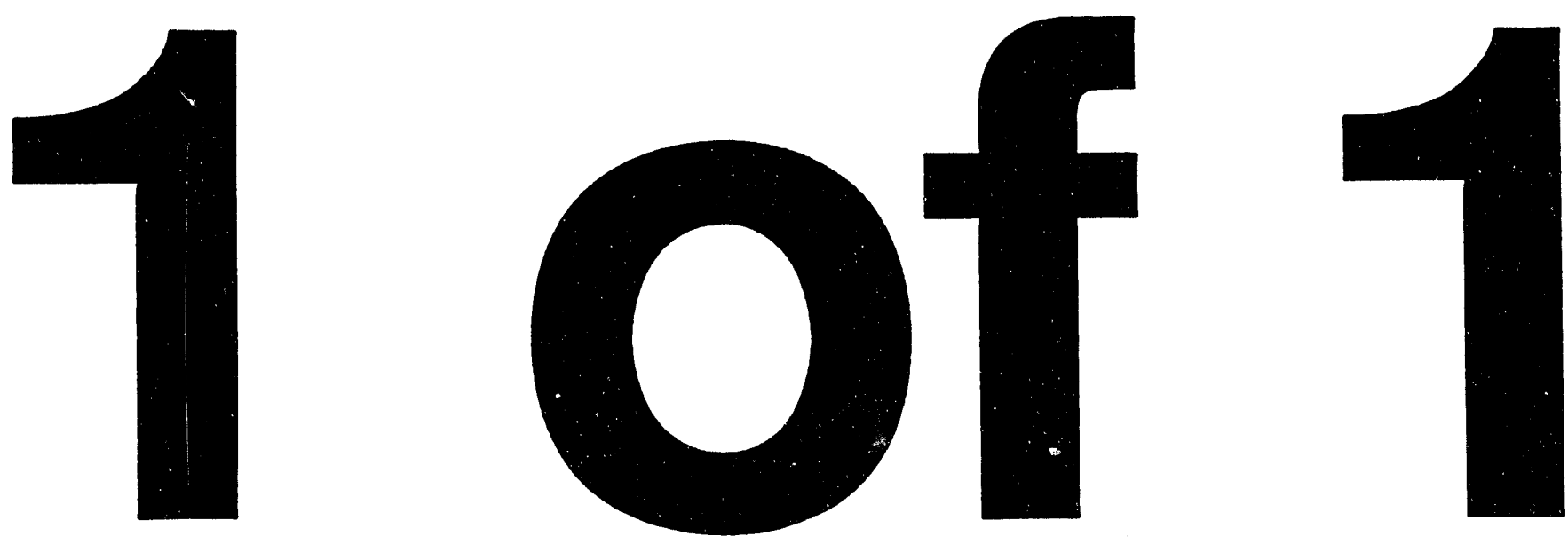


\section{(a) 1 \\ Department of Energy Programmatic Spent Nuclear Fuel Management and \\ Idaho National Engineering Laboratory Environmental Restoration and Waste Management Programs Draft Environmental Impact Statement}

\section{Summary}

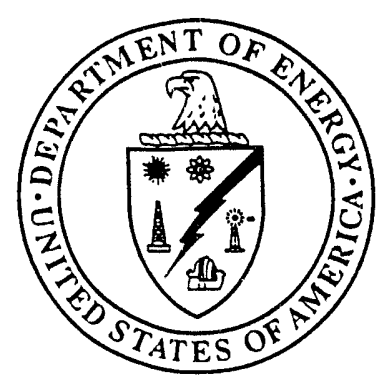

June 1994 


\section{DISCLAIMER}

This report was prepared as an account of work sponsored by an agency of the United States Government. Neither the United States Government nor any agency thereof, nor any of their employees, makes any warranty, express or implied, or assumes any legal liability or responsibility for the accuracy, completeness, or usefulness of any information, apparatus, product, or process disclosed, or represents that its use would not infringe privately owned rights. Reference herein to any specific commercial product, process, or service by trade name, trademark, manufacturer, or otherwise does not necessarily constitute or imply its endorsement, recommendation, or favoring by the United States Government or any agency thereof. The views and opinions of authors expressed herein do not necessarily state or reflect those of the United States Government or any agency thereof. 


\section{Department of Energy \\ Washington, DC 20585 \\ June 20, 1994}

Dear Citizen:

This summary pertains to the draft Environmental Impact Statement (EIS) for Programmatic Spent Nuclear Fuel Management and Idaho National Engineering Laboratory Environmental Restoration and Waste Management Programs. The Department of Energy (DOE) has prepared this draft in compliance with the National Environmental Policy Act and implementing regulations. Volume 1 of this draft EIS analyzes alternatives for the management of existing and reasonably foreseeable inventories of spent nuclear fuel (SNF) within the DOE complex. Site-specific analyses, provided in appendices, support the discussion of the environmental consequences related to five alternative approaches for managing the Department's spent nuclear fuel through the year 2035. Volume 2 of this draft EIS is a detailed sitewide analysis of environmental restoration and waste management activities at the Idaho National Engineering Laboratory (INEL). DOE will use this analysis to support facility-specific decisions regarding new, continued or discontinued environmental restoration and waste management operations through the year 2005.

You are invited to comment on the draft EIS. A complete copy of the draft EIS and a list of reference documents are available in public reading rooms and information locations. The addresses of these reading rooms and information locations are included in this Summary. To request additional copies of the Summary, Volume 1, Volume 2, the Appendices or reference documents, please call 1-800-682-5583, between 6:00 a.m. and 11:00 p.m. Mountain Daylight Time.

The public comment period on the draft EIS will extend through September 30, 1994. Written comments should be postmarked no later than that date and sent to:

Public Comments on the SNF and INEL EIS

Attention: Thomas L. Wichmann

U.S. Department of Energy

Idaho Operations office

P. 0. Box 3189

Idaho Falls, ID 83403-3189

Comments may be stated over the telephone or transmitted by facsimile by calling 1-800-682-5583. Comments may al so be presented at 20 public hearings at locations listed on the back of this letter. We will consider all comments in preparing the final EIS, which is scheduled to be issued by April 30, 1995. No decisions will be made until the final EIS is issued and a 30-day waiting period has elapsed.

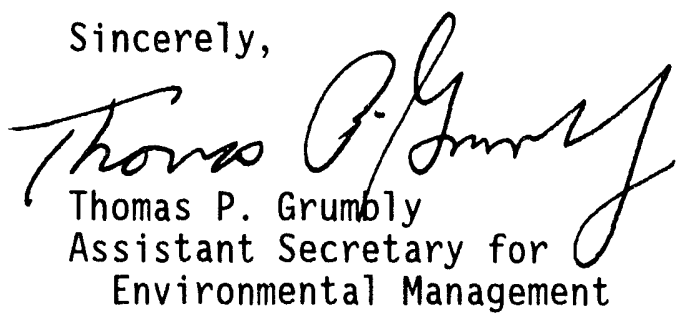


SNF AND INEL ER\&WM EIS PUBLIC COMMENT HEARING SCHEDULE

\begin{tabular}{|c|c|c|c|}
\hline SITE & DATE & TIME & LOCATION \\
\hline Portsmouth. VA & Monday, July 18, 1994 & $2: 00$ to $5: 00$ p.m. & $\begin{array}{l}\text { Willett Hall, } \\
3701 \text { Willett Drive }\end{array}$ \\
\hline Newport News, VA & Monday, July 18, 1994 & 7:00 to $11: 00$ p.m. & $\begin{array}{l}\text { Ferguson High School Aud., } \\
11 \text { Shoe lane }\end{array}$ \\
\hline Portsmouth, NH & Wednesday, July 20, 1994 & $1: 00$ to $5: 00$ p.m. & $\begin{array}{l}\text { Portsmouth City Council Chambers, } \\
1 \text { Junkins Avenue }\end{array}$ \\
\hline Kittery, ME & Wednesday, July 20, 1994 & $7: 00$ to $11: 00$ p.m. & $\begin{array}{l}\text { Traip Academy, } \\
\text { Williams Avenue }\end{array}$ \\
\hline Ballston Spa, NY & Friday, July 22, 1994 & $\begin{array}{l}\text { 1:00 to } 4: 00 \text { p.m. } \\
6: 00 \text { to } 9: 00 \text { p.m. }\end{array}$ & $\begin{array}{l}\text { Ballston Spa High School Aud., } \\
480 \text { Garret Road }\end{array}$ \\
\hline Seattle, WA & Tuesday, July 26, 1994 & $\begin{array}{l}11: 30 \text { a.m. to } \\
\text { 3:30 p.m. }\end{array}$ & $\begin{array}{l}\text { Federal Bldg, Fourth Floor Aud, } \\
915 \text { Second Avenue }\end{array}$ \\
\hline Bremerton, WA & Tuesday, July 26, 1994 & $7: 00$ to $11: 00$ p.m. & $\begin{array}{l}\text { Bremerton High School Aud, } \\
1500 \text { 13th Street }\end{array}$ \\
\hline Pearl City, HI & Thursday, July 28, 1994 & $\begin{array}{l}12: 00 \text { to } 4: 00 \text { p.m. } \\
6: 00 \text { to } 10: 00 \text { p.m. }\end{array}$ & $\begin{array}{l}\text { Leeward Comm. Coll. Theater, } \\
\text { 96-045 Ala Ike Street }\end{array}$ \\
\hline Arlington, VA & Tuesday, August 2, 1994 & $\begin{array}{l}1: 30 \text { to } 4: 30 \text { p.m. } \\
6: 30 \text { to } 9: 30 \text { p.m. }\end{array}$ & $\begin{array}{l}\text { Crystal Gateway Marriott, } \\
1700 \text { Jefferson Davis Hwy. }\end{array}$ \\
\hline Las Vegas, NV & Thursday, August 4, 1994 & $\begin{array}{l}1: 30 \text { to } 4: 30 \text { p.m. } \\
6: 30 \text { to } 9: 30 \text { p.m. }\end{array}$ & $\begin{array}{l}\text { Cashman Field, } \\
850 \text { Las Vegas Blvd. North }\end{array}$ \\
\hline Portland, OR & Tuesday, August 9, 1994 & $\begin{array}{l}1: 30 \text { to } 4: 30 \text { p.m. } \\
6: 30 \text { to } 9: 30 \text { p.m. }\end{array}$ & $\begin{array}{l}\text { Portland Hilton, } \\
921 \text { Southwest Sixth Avenue }\end{array}$ \\
\hline Pasco, WA & Thursday, August 11, 1994 & $\begin{array}{l}\text { 1:30 to } 4: 30 \text { p.m. } \\
6: 30 \text { to } 9: 30 \text { p.m. }\end{array}$ & $\begin{array}{l}\text { Red Lion Inn Pasco, } \\
2525 \text { North 20th Street }\end{array}$ \\
\hline Oak Ridge, TN & Tuesday, August 16, 1994 & $\begin{array}{l}1: 30 \text { to } 4: 30 \text { p.m. } \\
6: 30 \text { to } 9: 30 \text { p.m. }\end{array}$ & $\begin{array}{l}\text { Garden Plaza Hotel, } \\
215 \text { South Illinois Avenue }\end{array}$ \\
\hline Kingston, TN & Thursday, August 18, 1994 & $6: 30$ to $9: 30$ p.m. & $\begin{array}{l}\text { Kingston Elem. School, } \\
2009 \text { Kingston Hwy. }\end{array}$ \\
\hline Moscow, ID & Tuesday, August 23, 1994 & $\begin{array}{l}\text { 1:30 to } 4: 30 \text { p.m. } \\
6: 30 \text { to } 9: 30 \text { p.m. }\end{array}$ & $\begin{array}{l}\text { University Inn, } \\
1516 \text { Pullman Road }\end{array}$ \\
\hline Savannah, GA & Tuesday, August 23, 1994 & $\begin{array}{l}\text { 1:30 to } 4: 30 \text { p.m. } \\
6: 30 \text { to } 9: 30 \text { p.m. }\end{array}$ & $\begin{array}{l}\text { DeSoto Hilton, } \\
15 \text { East Liberty }\end{array}$ \\
\hline Boise, ID & Thursday, August 25, 1994 & $\begin{array}{l}1: 30 \text { to } 4: 30 \text { p.m. } \\
6: 30 \text { to } 9: 30 \text { p.m. }\end{array}$ & $\begin{array}{l}\text { Boise Centre on the Grove } \\
850 \text { West Front Street }\end{array}$ \\
\hline North Augusta, SC & Thursday, August 25, 1994 & $\begin{array}{l}1: 30 \text { to } 4: 30 \text { p.m. } \\
6: 30 \text { to } 9: 30 \text { p.m. }\end{array}$ & $\begin{array}{l}\text { North Augusta Comm. Ctr., } \\
495 \text { Brookside Avenue }\end{array}$ \\
\hline Twin Falls, ID & Tuesday, August 30, 1994 & $\begin{array}{l}\text { 1:30 to } 4: 30 \text { p.m. } \\
6: 30 \text { to } 9: 30 \text { p.m. }\end{array}$ & $\begin{array}{l}\text { Weston Plaza, } \\
1350 \text { Blue Lakes Boulevard North }\end{array}$ \\
\hline Idaho Falls, ID & Thursday, September 1, 1994 & $\begin{array}{l}1: 30 \text { to } 4: 30 \text { p.m. } \\
6: 30 \text { to } 9: 30 \text { p.m. }\end{array}$ & $\begin{array}{l}\text { Shilo Inn, } \\
780 \text { Lindsay Boulevard }\end{array}$ \\
\hline
\end{tabular}

Further information about the public hearings can be obtained by calling 1-800-682-5583. 


\section{COVER SHEET}

RESPONSIBLE AGENCIES: Lead Federal Agency: U.S. Department of Energy Cooperating Federal Agency: U.S. Department of the Navy

TITLE: Department of Energy Programmatic Spent Nuclear Fuel Management and Idaho National Engineering Laboratory Environmental Restoration and Waste Management Programs Draft Environmental Impact Statement.

CONTACT: For further information on this Environmental Impact Statement call or contact:

Public Comments on the SNF and INEL EIS

Attention: Tom Wichmann

DOE Idaho Operations Office

P.O. Box 3189

Idaho Falls, ID 83403-3189

$1-800-682-5583$

For general information on the U.S. Department of Energy NEPA process call 1-800-472-2756 to leave a message or contact:

Carol Borgstrom, Director

Office of NEPA Oversight (EH-25)

U.S. Department of Energy

1000 Independence Avenue, SW

Washington, D.C. 20585

202-586-4600

ABSTRACT: This document analyzes at a programmatic level the potential environmental consequences over the next $\mathbf{4 0}$ years of alternatives related to the transportation, receipt, processing, and storage of spent nuclear fuel under the responsibility of the U.S. Department of Energy. It also analyzes the site-specific consequences of the Idaho National Engineering Laboratory sitewide actions anticipated over the next 10 years for waste and spent nuclear fuel management and environmental restoration. For programmatic spent nuclear fuel management, this document analyzes alternatives of no action, decentralization, regionalization, centralization and the use of the plans that existed in 1992/1993 for the management of these materials. For the Idaho National Engineering Laboratory, this document analyzes alternatives of no action, ten-year plan, minimum and maximum treatment, storage, and disposal of U.S. Department of Energy wastes.

PUBLIC COMMENTS: Public meetings on the Draft Environmental Impact Statement will be announced in June 1994. Written and oral comments on the Draft Environmental Impact Statement will be accepted until September 30, 1994, at the Idaho address and telephone number provided above. The U.S. Department of Energy will consider these public comments in preparing the Final Environmental Impact Statement. 


$$
1
$$


he U.S. Department of Energy's (DOE's) Environmental Impact

Statement (EIS) for Programmatic Spent Nuclear Fuel Management and Idaho National Engineering Laboratory Environmental Restoration and Waste Management Programs [DOE/EIS0203-D] is divided into two volumes:

- Volume 1, DOE Programmatic Spent Nuclear Fuel Management

- Volume 2, Idaho National Engineering Laboratory Environmental Restoration and Waste Management Programs (including site-specific spent nuclear fuel management).

Volume 1 comprises five primary sections and nine key appendices. The five primary sections provide (a) an introduction and overview to DOE's spent nuclear fuel management program throughout the nation, (b) the purpose and need for action to manage spent nuclear fuel, (c) management alternatives that are under consideration, (d) the affected environment, and (e) potential environmental consequences caused by the implementation of each alternative. The information contained in these sections relies, in part, upon more detailed information and analyses in the nine key appendices. These appendices describe and assess the site-specific spent nuclear fuel management programs at three primary DOE facilities and several alternative sites, the naval reactors spent nuclear fuel management program, offsite transportation of spent nuclear fuel, and environmental consequences data. Two additional appendices include a glossary and a list of acronyms and abbreviations.

Volume 2 is similarly constructed. Five primary sections are presented that provide (a) the purpose and need for an integrated 10-year environmental restoration, waste management, and spent nuclear fuel management program at the Idaho National Engineering Laboratory,

(b) background, (c) management alternatives under consideration, (d) the affected environment, and (e) potential environmental consequences associated with the implementation of each alternative. The information presented in these sections relies, in part, upon four key appendices, which include a basic description of radioactivity and toxicology (chemical effects), agency consultation letters, detailed project summaries, and technical methodologies and key data. Two additional appendices include a glossary and a list of acronyms and abbreviations.

Each volume provides an index and a glossary, as well as a list of references to enable the reader to further review and research selected topics. DOE has established reading rooms and information locations across the United States where these references may either be reviewed or obtained for review through interlibrary loan. The addresses, phone numbers, and hours of operation for these reading rooms and information locations are provided at the end of this EIS Summary.

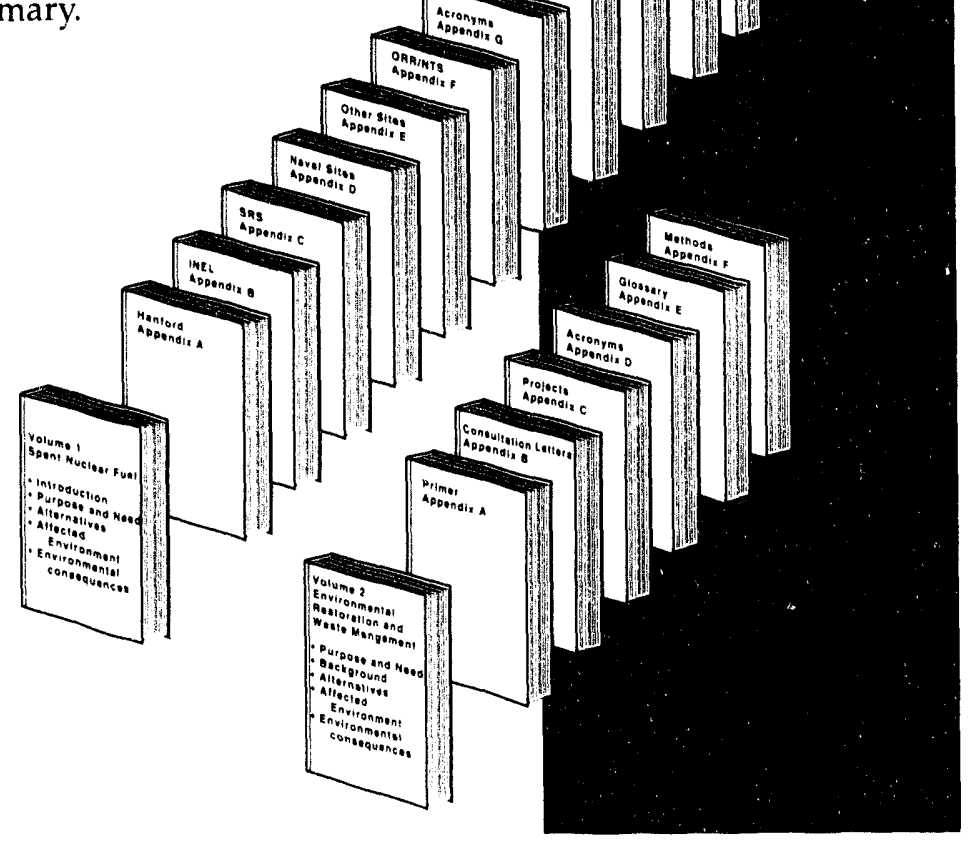




$$
\longrightarrow
$$

iv Summary 
Reader's Guide

Introduction ...

National Environmental Policy Act Process ..................

General Scope of the Environmental Impact Statement ............................ 2

Volume 1-Spent Nuclear Fuel

Overview

History of Spent Nuclear Fuel Management

Purpose and Need for Future Spent Nuclear Fuel Management.

Alternatives

No Action Alternative

Decentralization Alternative

1992/1993 Planning Basis Alternative …..................................................... 14

Regionalization Alternative ......................................................... 17

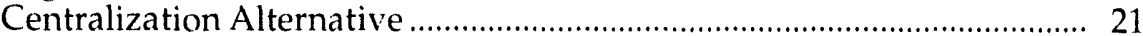

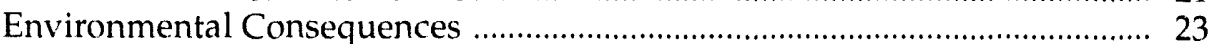

Number of Shipments .............................................................................. 23

Public and Worker Health Effects ..................................................... 23

Spent Nuclear Fuel-Related Employment ........................................ 28

Generation of Radioactive Wastes ........................................................ 30

Impact on DOE and Navy Missions ................................................... 33

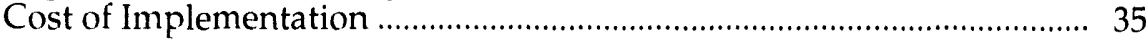

Cumulative Impacts ........................................................................... 35

Consultations and Environmental Requirements ..................................... 37

Relationship Between Volumes 1 and 2 ................................................. 39

Volume 2-INEL Environmental Restoration and Waste Management ....... 41

Overview ................................................................................................. 41

Waste Management, Environmental Restoration, Spent Nuclear Fuel, and

Technology Development at the INEL .................................................... 43

Waste Management .......................................................................... 43

Environmental Restoration ........................................................... 13

Spent Nuclear Fuel ............................................................................. 44

Technology Development .................................................................... 46

Purpose and Need for Future Environmental Restoration and Waste

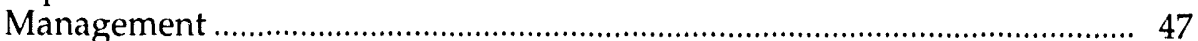

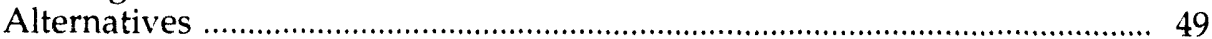

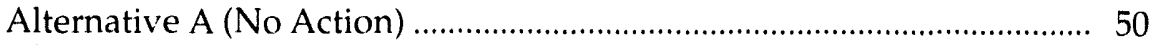

Alternative B (Ten-Year Plan) ........................................................ 50

Alternative C (Minimum Treatment, Storage, and Disposal) .................. 51

Alternative D (Maximum Treatment, Storage, and Disposal) ................ 53

Affected Environment at the INEL .................................................. 55

Environmental Consequences .............................................................. 57

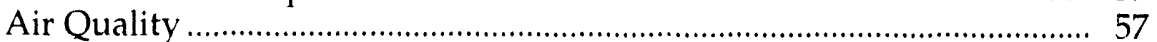

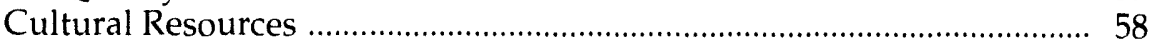

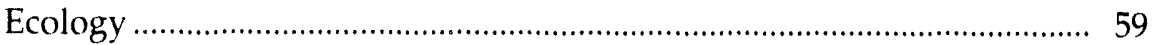

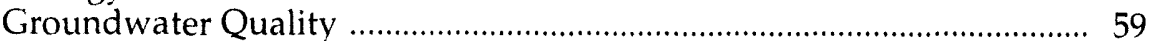

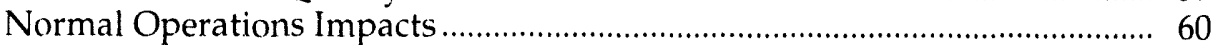

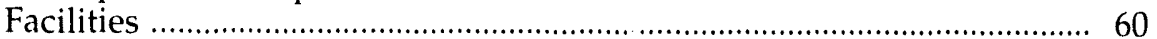

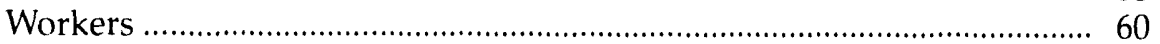

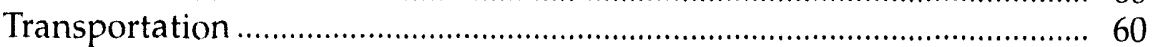

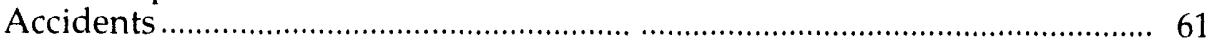

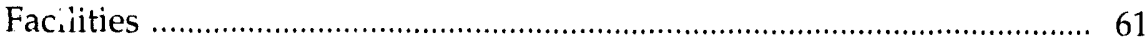

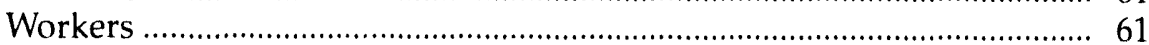

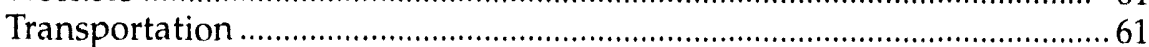

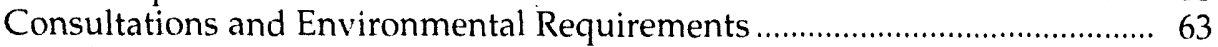

Attachment-Reading Rooms and Information Locations ......................... 65

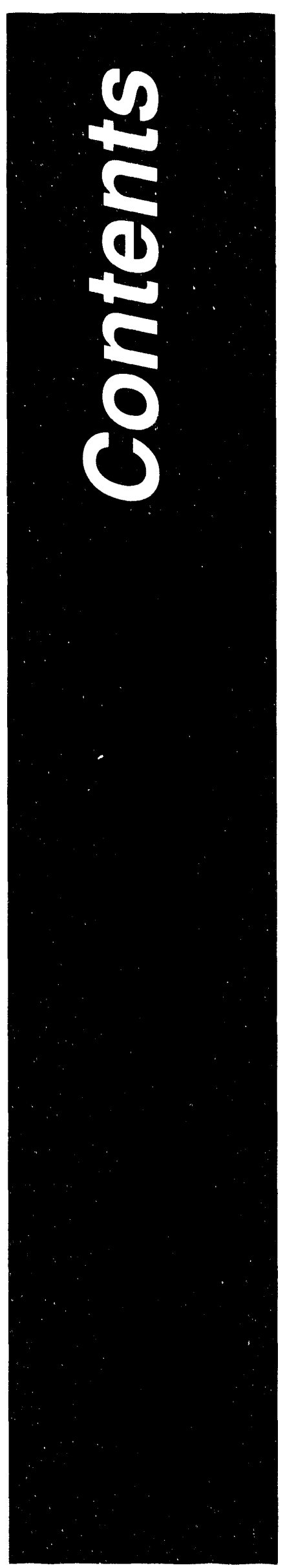




$$
\longrightarrow
$$

| 


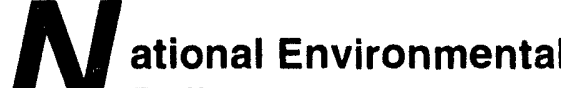 Policy Act Process}

The U.S. Department of Energy (DOE) is currently evaluating its options for two separate, but related, sets of decisions. The first involves programmatic (DOE-wide) approaches to DOE's management of spent nuclear fuel. The second involves site-specific approaches regarding the future direction of environmental restoration and waste management programs (including spent nuclear fuel) at the Idaho National Engineering Laboratory.

A key element of DOE's decisionmaking is a thorough understanding of the environmental impacts that may occur during the implementation of the proposed action. The National Environmental Policy Act of 1969), as amended, provides Federal agency decisionmakers with a process to consider potential environmental consequences (both positive and negative) of proposed actions before agencies make decisions. In following this process, DOE has prepared this draft Environmental Impact Statement (EIS) to assess various management alternatives and to provide the necessary background, data, and analyses to help decisionmakers and the public understand the potential environmental impacts of each alternative. Following consideration of public comments, DOE will prepare a final EIS. DOE's decisions will be discussed in a Record of Decision to be issued following completion of the final EIS.

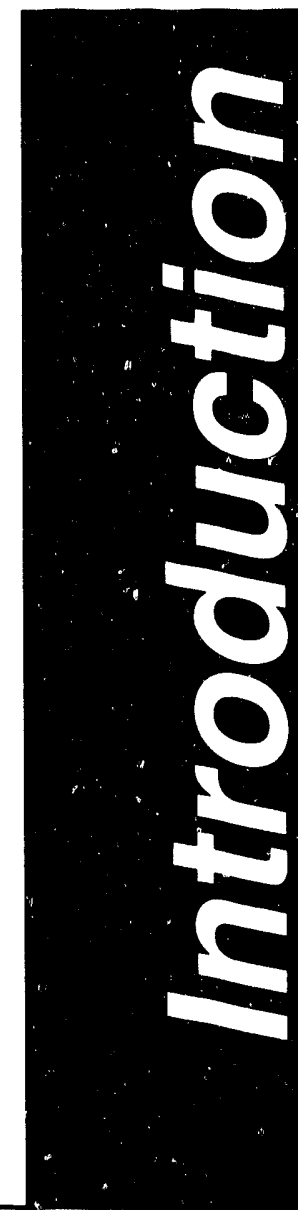

\section{National Environmental Policy Act}

National Environmental Policy Act of 1969: A law that requires Federal agencies to consider in their decisionmaking processes the potential environmental effects of proposed actions and analyses of alternatives and measures to avoid or minimize the adverse effects of a proposed action.

Alternatives: The range of reasonable options, including the No Action alternative, considered in selecting an approach to meeting the proposed objectives.

Environmental Impact Statement: A detailed environmental analysis for a proposed major Federal action that could significantly atfect the quality of the human environment. A tool to assist in decisionmaking, it describes the positive and negative environmental effects of the proposed undertaking and alternatives.

Record of Decision: A concise public record of DOE's decision, which discusses the decision, identifies the alternatives (specifying which ones were considered environmentally preferable), and indicates whether all practicable means to avoid or minimize environmental harm from the selected alternative were adopted (and if not, why not). 

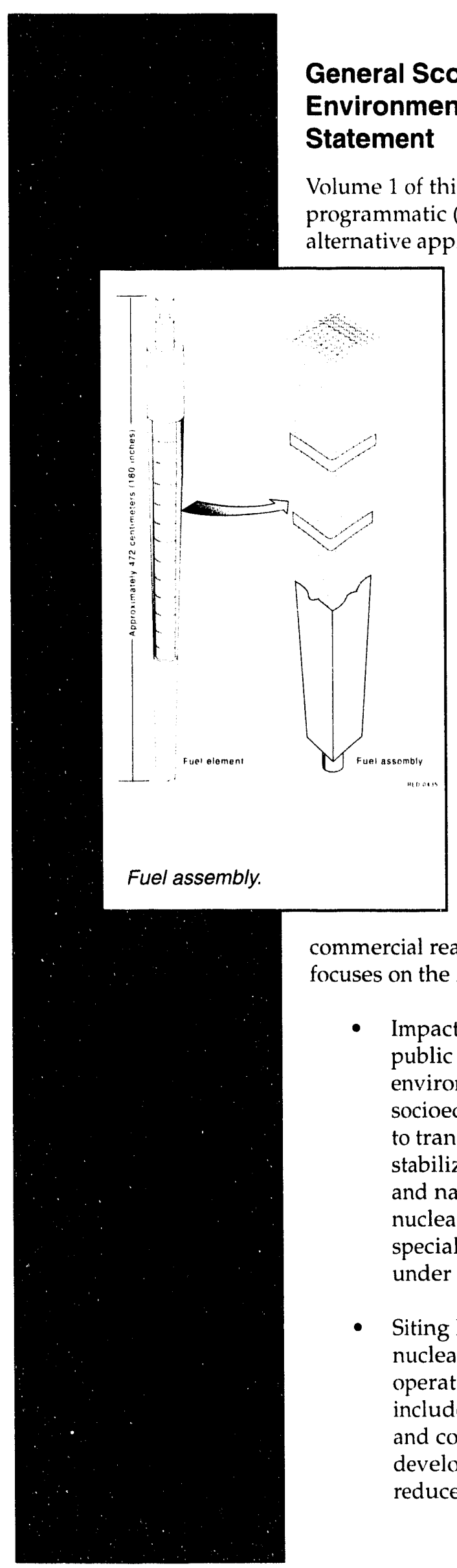
commercial reactors. Volume 1 focuses on the following:

- Impacts to worker safety, public health, the environment, and socioeconomic factors related to transporting, receiving, stabilizing, and storing DOE and naval reactor spent nuclear fuel, as w'ell as special-case commercial fuels under DOE responsibility.

- Siting locations for spent nuclear fuel management operations, which may include storing, stabilizing, and continuing research and development. (Stabilizing reduces fuel deterioration.)
- Fuel stabilization activities required for safe interim storage such as canning of degraded fuels or processing, research and development of spent nuclear fuel management technologies, and pilot programs.

DOE will not address the ultimate disposition (final step in which material is either processed or disposed of) of spent nuclear fuel in this EIS. Nor will DOE select spent nuclear fuel stabilization technologies on the basis of this EIS. These technology-based decisions are more appropriately dealt with on a fucltype basis. DOE will prepare additional National Environmentai Policy Act documentation for researct: and development and characterization activities that help select technologies to place the fuel in a form sui'able for ultimate disposition (this is commonly referred to as "tiering" within the National Environmental Policy Act process).

Except for special-case commercial fuel, management of spent nuclear fuel from commercial nuclear power plants is not the subject of this EIS.

Volume 2 of this EIS addresses alternative approaches for management of DOE's environmental restoration, waste management, and spent nuclear fuel activities over the next 10 years at the Idaho National Engineering Laboratory. This volume includes evaluations of potential environmental impacts associated with Idaho National Engineering Laboratory programs and site activities that contribute to waste streams requiring handling or disposal. Waste management activities are evaluated at both the site-wide and project-specific levels. Environmental restoration activities are addressed only at the site-wide level. Volume 2 considers site-specific 
activities for spent nuclear fuel management, including fuel receipt, transportation, characterization, stabilization, storage, and technology development for ultimate disposition.

Volume 2 evaluates impacts of operations or programs associated with the spent nuclear fuel, environmental restoration, and waste management programs at the Idaho National Engineering Laboratory. Other activities are discussed when they are relevant to understanding the affected environment or are expected to occur during the next 10 years, and are included as part of the cumulative effects analysis.

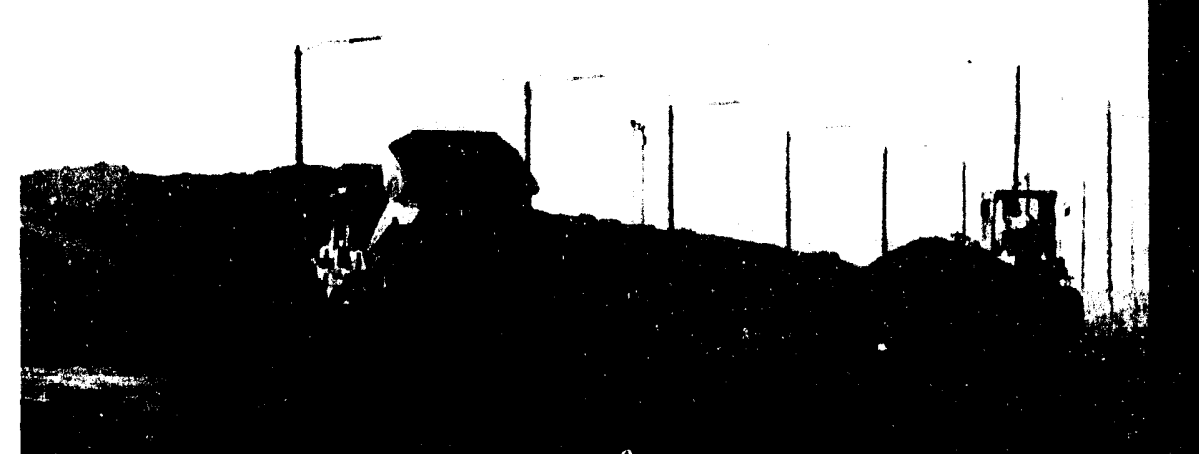

$\theta$

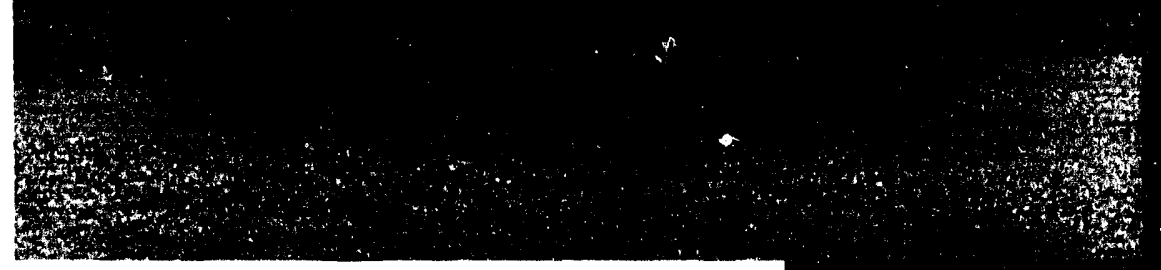

Waste management activities at the Idaho National Engineering Laboratory.

This EIS does not evaluate the DOEwide programmatic alternatives for environmental restoration and waste management, which are being evaluated in a separate programmatic EIS to be issued in draft form in the fall of 1994. However, the alternatives presented in Volume 2 have been developed to be consistent with the programmatic objectives of the Environmental Management Programmatic EIS, which DOE does not expect to be completed before the Record of Decision is signed for the EIS summarized here. Any conflicts between these Records of Decision will be evaluated and, as appropriate, additional National Environmental Policy Act documentation will be prepared in accordance with applicable regulations. 


$$
\longrightarrow
$$

4 Summary 


\section{verview}

The DOE Spent Nuclear Fuel Management Program is intended to (a) provide interim storage and management of fuel at specified locations until ultimate disposition, (b) stabilize the fuel as required for environmentally safe storage and protection of human health (for both workers and the public), (c) increase safe storage capacity by replacing facilities that cannot meet current standards and providing additional capacity for newly generated spent nuclear fuel, (d) conduct research and development initiatives to support safe storage or ultimate disposition, and (e) examine fuel generated by the Naval Nuclear Propulsion Program. DOE's spent nuclear fuel management responsibilities include fuel generated by DOE production and research and development reactors, naval reactors, university and foreign research reactors, other miscellaneous generators, and specialcase commercial reactors. The primary goals of the management progran are to reduce the risk of nuclear accidents during transportation and storage and to minimize the release of radionuclides to the environment where they can pose hazards to human health, plants, and animals.

\section{History of Spent Nuclear Fuel Management}

Most DOE spent nuclear fuel is currentlv stored at three primary locations: the Hanford Site (State of Washington), the Idaho National Engineering Laboratory (State of Idaho), and the Savannah River Site

\section{What Is Spent Nuclear Fuel?}

Spent nuclear fuel is fuel that has been withdrawn from a nuclear reactor following irradiation, the constituent elements of which have not been separated. For purposes of this EIS, spent nuclear fuel inventory also includes uranium/neptunium target material, blanket subassemblies, pieces of fuel, and debris.

Fuel in a reactor consists of fuel assemblies that come in many configurations but generally consist of the fuel matrix, cladding, and structural hardware. The matrix, which contains the fissionable material (typically uranium oxide or uranium metal), is typically plates or cylindrical pellets.

The cladding (typically zirconium, aluminum, or stainless steel) surrounds the fuel, confining and protecting it. For gas-cooled reactors, this may be a ceramic coating over fuel particles. Structural parts hold fuel rods or plates in the proper configuration and direct coolant flow (typically water) over the

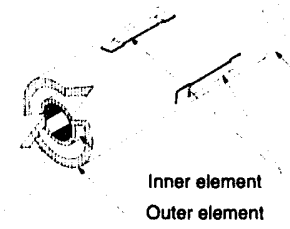

Typical fuel element under consideration in this EIS.

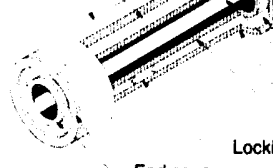
Zircaloy cladding End caps fuel. Structural hardware is generally nickel alloys, stainless steel, zirconium, or aluminum, or, for gas-cooled reactors, graphite.

The radiation of most concern from spent nuclear fuel is gamma rays. Although the radiation levels can be very high, the gamma ray intensities are readily reduced by shielding the fuel elements with such materials as concrete, lead, steel, and water. The shielding thicknesses are dependent on the energy of the radiation source, the desired protection level, and the density of the shielding material. Typically, shielding thicknesses for concrete or lead are much smaller than for water.

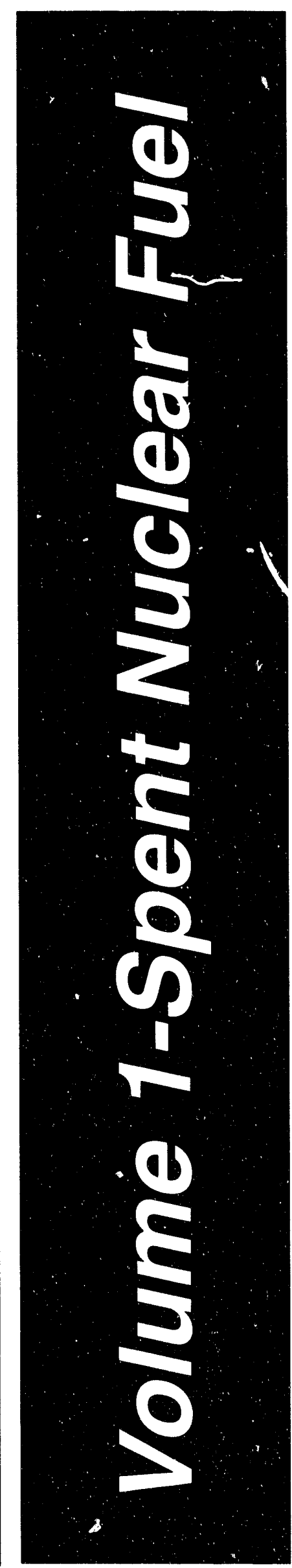




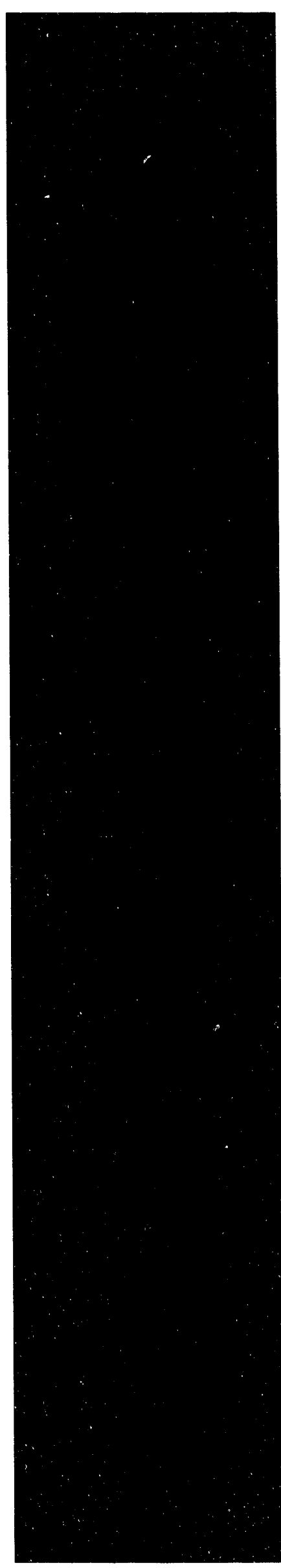

(State of South Carolina) (Figure 1). Much smaller quantities of spent nuclear fuel remain at other locations throughout the nation (see Figure 1). Historically, DOE has reprocessed spent nuclear fuel at the three primary locations to recover and recycle uranium and plutonium.

Much of the spent nuclear fuel at the three primary locations resulted from production reactors at the Hanford and Savannah River Sites. These reactors are no longer operating, but they previously provided material for DOE's defense programs and research and development programs. Smaller quantities of spent nuclear fuel at other locations have resulted from experimental reactor operations and from research conducted by approximately 55 university- and Government-owned test reactors. DOE is proposing to renew the policy to return spent nuclear fuel containing enriched uranium that originated in the United States and was used in small foreign research reactors, consistent with the U.S. Nuclear Weapons

Nonproliferation Policy. DOE also would accept spent nuclear fuel from development reactors, fuel used for destructive and nondestructive examination and testing, and other special-case fuel.

Since 1957, spent nuclear fuel from nuclear-powered naval vessels and naval reactor prototypes (operating reactors used for land-based training) has been transported from shipyards and prototype sites to the Naval Reactors Facility at the Idaho National Engineering Laboratory for testing sites? and examination. However, a court order dated June 28, 1993 now limits the number of shipments of spent nuclear fuel to ldaho. Therefore, most naval spent nuclear fuel is being retained at shipyards.

\section{Purpose and Need for Future Spent Nuclear Fuel Management}

DOE is responsible for developing and maintaining a capability to safely manage its spent nuclear fuel. During the last four decades, DOE and its predecessor agencies have transported, received, stored, and reprocessed approximately 100,000 metric tons" of spent nuclear fuel. Currently, approximately 2,700 metric tons of heavy metal of spent nuclear fuel that are now stored at various locations in the United States and overseas have not been reprocessed. This spent nuclear fuel is in a wide range of enrichments (that is, percent uranium-235), types, and conditions. By the year 2035, this

Should DOE leave the spent nuclear fuel where it is today, with most at 3 sites and small quantities at almost 50 other

Should DOE consolidate spent nuclear fuel storage at fewer sites to improve management efficiency?

Should DOE consolidate all spent nuclear fuel at a single site and stop spent nuclear fuel activities at other sites?

a. A metric ton of heavy metal is the unit used throughout this document to indicate the amount of spent nuclear fuel. It corresponds to 1,000 kilograms (2,200 pounds) of heavy metal (uranium, plutonium, thorium). 


\section{Existing Spent Nuclear Fuel Locations}

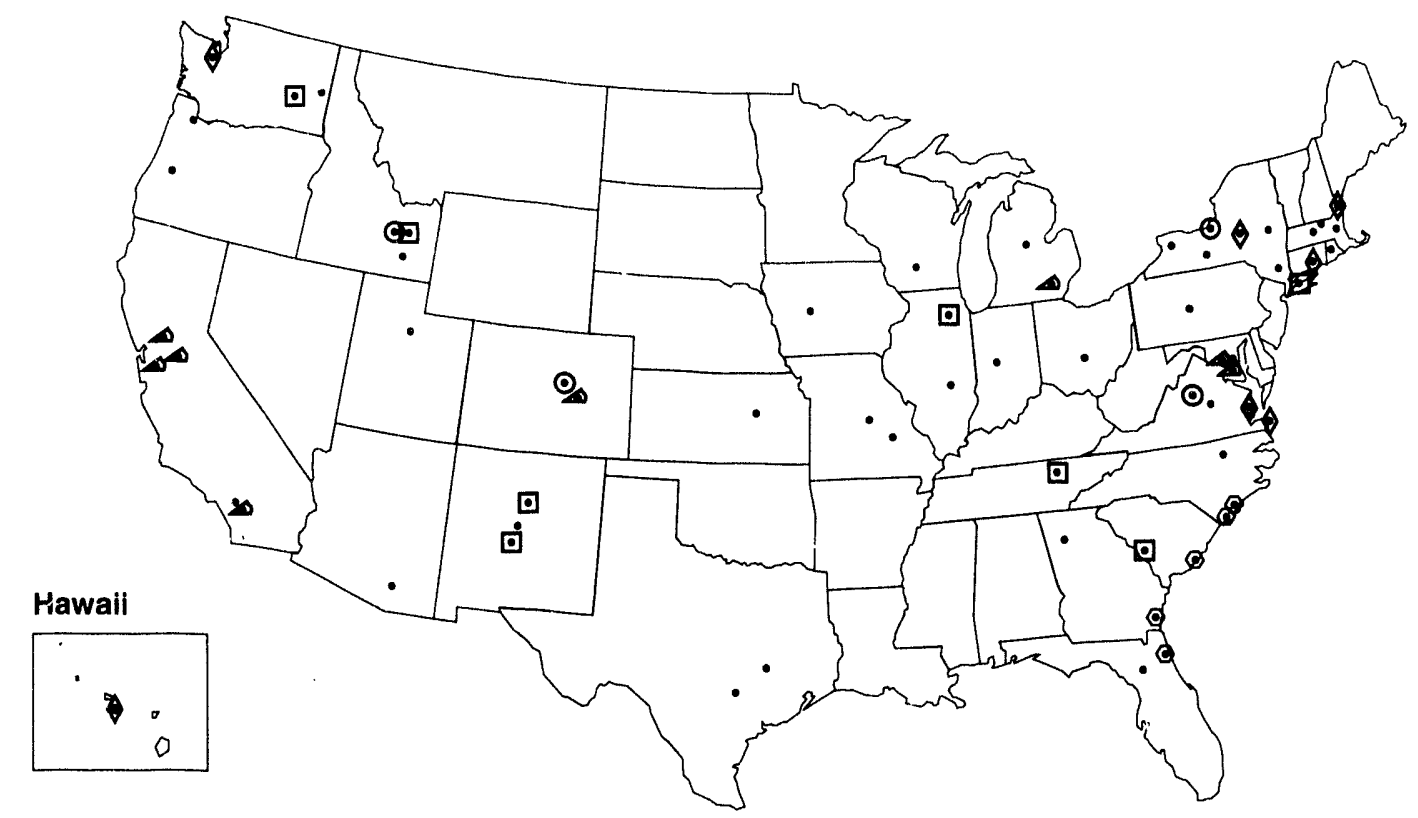

1995 Inventory (Metric Tons Heavy Metal) $^{a}$

\begin{tabular}{lr}
\hline Hanford & 2,133 \\
Idaho National & 289 \\
$\quad$ Engineering Laboratory & \\
Savannah River Site & 202 \\
Oak Ridge Reservation & 3 \\
Other DOE Facilities & 28 \\
Universities & 4 \\
Other & 16 \\
\hline Total & 2,675
\end{tabular}

\begin{tabular}{|c|c|}
\hline ( Naval Sites ${ }^{b}$ & State \\
\hline $\begin{array}{l}\text { Kesselring } \\
\text { Newport News } \\
\text { Norfolk } \\
\text { Pearl Harbor } \\
\text { Portsmouth } \\
\text { Puget Sound } \\
\text { Windsor }\end{array}$ & $\begin{array}{l}\text { New York } \\
\text { Virginia } \\
\text { Virginia } \\
\text { Hawaii } \\
\text { Maine } \\
\text { Washington } \\
\text { Connecticut }\end{array}$ \\
\hline
\end{tabular}

- DOE Facilities

Argonne National

Laboratory-East

Brookhaven National

Laboratory

Hanford

Idaho National

Engineering Laboratory

Los Alamos

National Laboratory

Oak Ridge Reservation

Sandia National

Laboratories

Savannah River Site
Legend

No. of locations

8

7

4

8

5

33

State

Illinois

New York

Washington

Idaho

New Mexico

Tennessee

New Mexico

South Carolina

a. A metric ton of heavy metal is the unit used throughout this document to indicate the amount of spent nuclear fuel. It corresponds to 1,000 kilograms (2,200 pounds) of heavy metal (uranium, plutonium, thorium).

b. Name of shipyard or site.

Figure 1. Locations of current spent nuclear fuel generators and storage sites. 


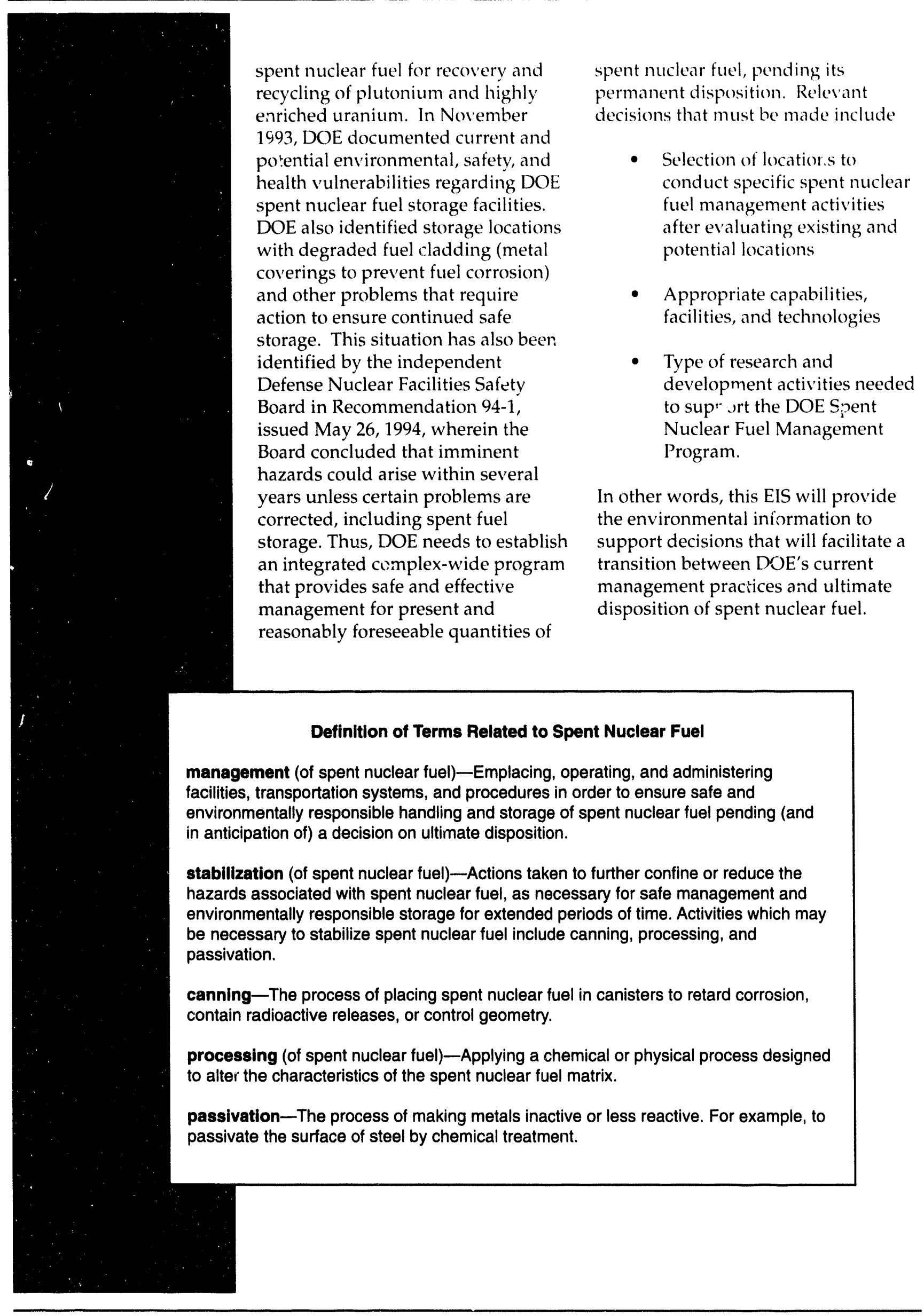


OE proposes to manage spent nuclear fuel during the next

40 years, pending ultimate disposition. A range of reasonable alternatives that supports the decisions to be made was determined to include variations of several components: (a) multiple storage locations, (b) the amounts of spent nuclear fuel shipped, (c) fuel stabilization methods (ways to reduce deterioration) required, (d) the number and types of storage facilities to be constructed, and (e) the scope of technology research and development efforts for management technologies.

In addition to those three DOE sites that have condurted extensive spent nuclear fuel management activities, four naval shipyards (Norfolk, Portsmouth, Pearl Harbor, and Puget Sound) and one prototype reactor site (Kesselring Site) were selected as potential storage locations for naval spent nuclear fuel. In response to public comments raised during the scoping process, DOE undertook a process for identifying possible alternative sites. The end result of the selection process was the inclusion and evaluation of two additional sites, the Oak Ridge Reservation (State of Tennessee) and the Nevada Test Site (State of Nevada). (The Nevada Test Site is not considered to be a preferred site because of the State's current role as the host site for the Yucca Mountain Site Characterization Project.) Figure 2 depicts the various alternatives, options, and locations that DOE is evaluating for spent nuclear fuel management.

The programmatic approach that DOE selects may be a combination of parts of the alternatives analyzed. These programmatic (DOE-wide) decisions will not select all site-specific spent nuclear fuel management options. Such decisions will be made following additional site-specific National Environmental Policy Act evaluations.
DOE has not yet selected a preferred programmatic alternative but will identify one in the final EIS following receipt and consideration of public comments on the draft EIS. However, the Navy, as a cooperating agency, has identified its preferred alternative-to continue to conduct refueling and defueling of nuclearpowered vessels and prototypes, and to transport spent nuclear fuel to the Idaho National Engineering Laboratory for rull examination and interim storage, using the same practices as in the past.

\section{Alternatives for the Management of DOE Spent Nuclear Fuel}

\section{No Action}

Take minimum actions required for safe and secure management of spent nuclear fuel at or close to the generation site or current storage location.

\section{Decentralization}

Store most spent nuclear fuel at or close to the generation site or current storage location with limited shipments to DOE facilities.

\section{2/1993 Planning Basis}

Transport and store newly generated spent nuclear fuel at the Idaho National Engineering Laboratory or Savannah River Site.

\section{Regionalization}

Distribute existing and projected spent nuclear fuel among DOE sites based primarily on fuel type (Subalternative A) or geographic location (Subalternative B).

\section{Centralization}

Manage all existing and projected spent nuclear fuel inventories from DOE and the Navy at one site until ultimate disposition.

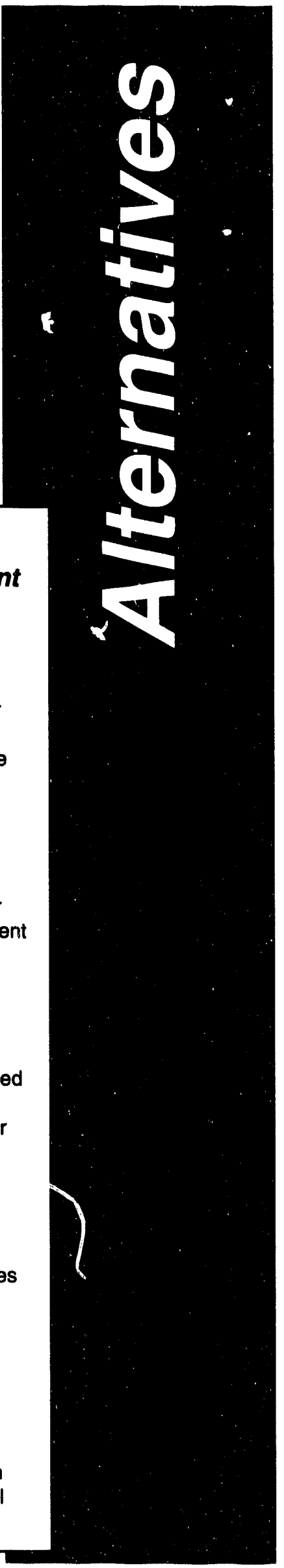




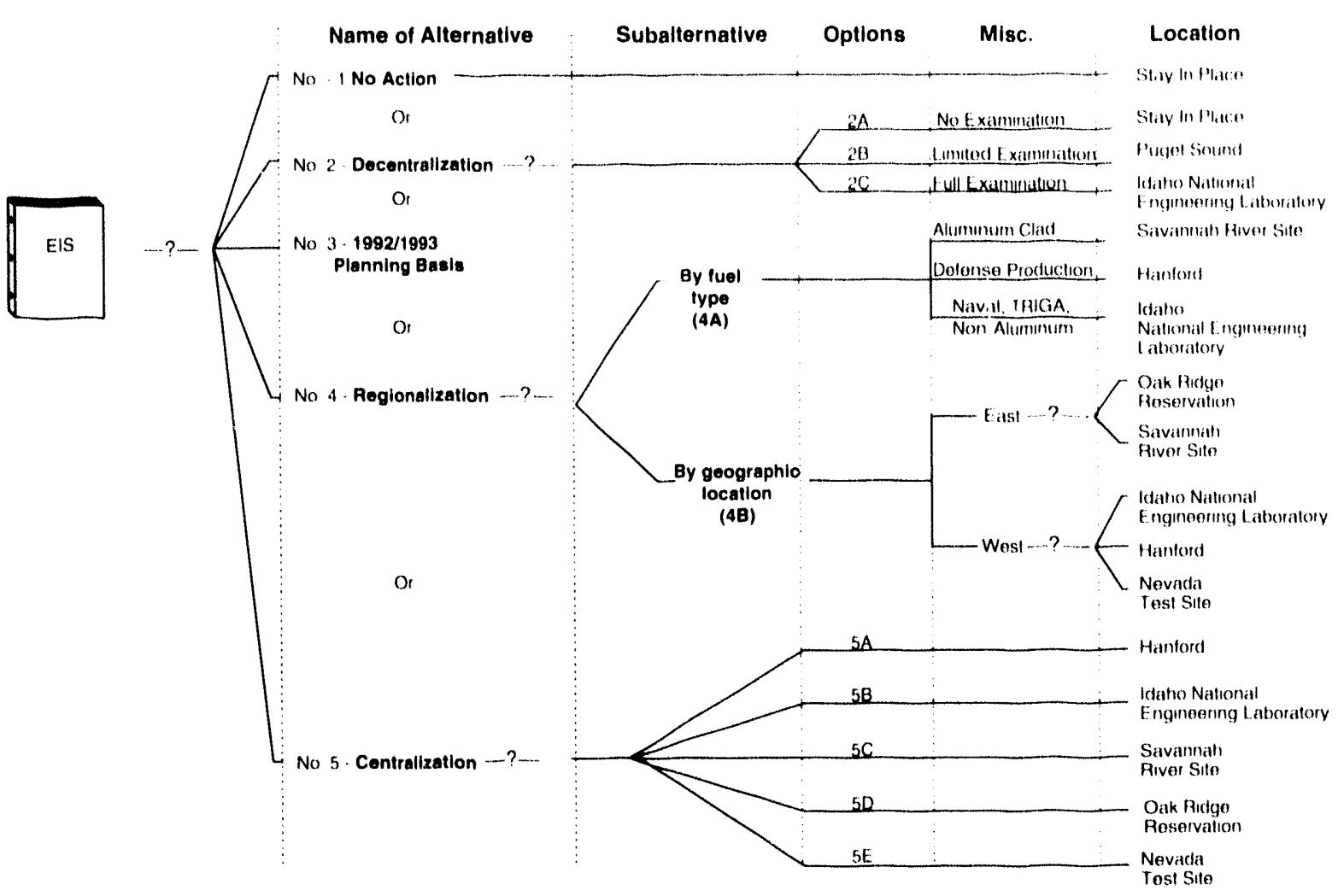

Note Question marks note decisions to he made (only one alternative or option with he chosen at these pounts)

Figure 2. Alternatives for management of DOE spent nuclear fuel.

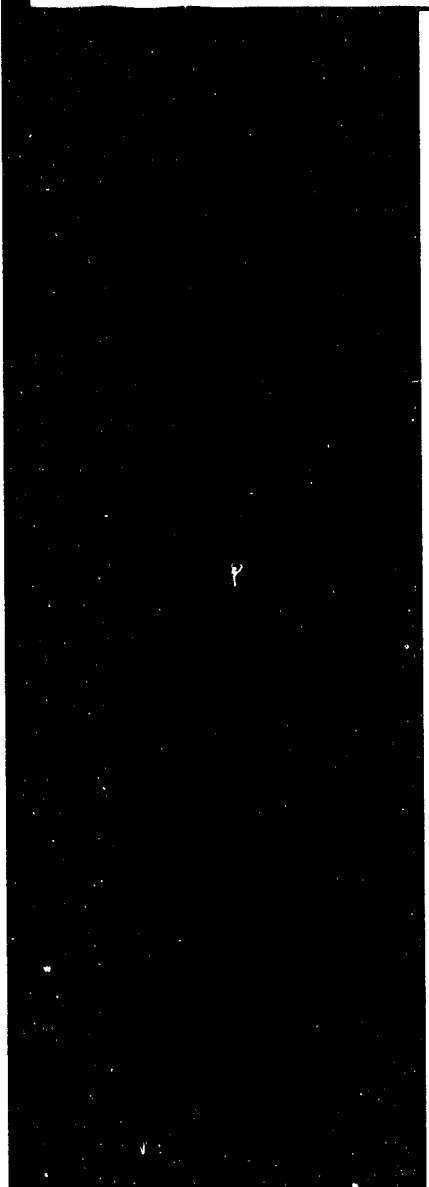

\section{No Action Alternative}

In the No Action alternative, which provides a baseline for comparison, DOE would limit actions to the minimum necessary for safe and secure management of spent nuclear fuel at or near the point where it is generated or currently located (Figure 3). Under this alternative, both small and large DOE sites, naval shipyards and prototypes, university and other non-DOF domestic reactors, and foreign research reactors would independently manage their fuel onsite. Naval spent nuclear fuel at the Newport News Shipyard would be transferred to Norfolk Naval Shipyard for retention.

No spent nuclear fucl would be transported between DO) sites for management after about a three-year transition period, during which additional naval fuel shipments would be sent to the ldaho National
Engineering Laboratory. Current technology development activities related to spent nuclear fuel management would continue within DOE.

Naval reactors would be refueled and defueled as planned. Naval spent nuclear fuel would be stored in shipping containers at the navial or DOE facility where refueling and defueling is conducted. This alternative would reguire about a three-year transition period to obtain additional approved containers for storage. During the transition peried, fuel would be transported to the Idaho National Engineering Laboratory for examination at the Expended core lacility: The shipping containers would be unloaded and reused for additional refucling and defuelings. However, after the transition period, the fuel remosed from naval reactors would remain in storigge at the nowial sites and the 


\section{No Action Alternative}

Radiation Risk

Estimated latent cancer fatalities less than

1 over 40-year period for normal operations.

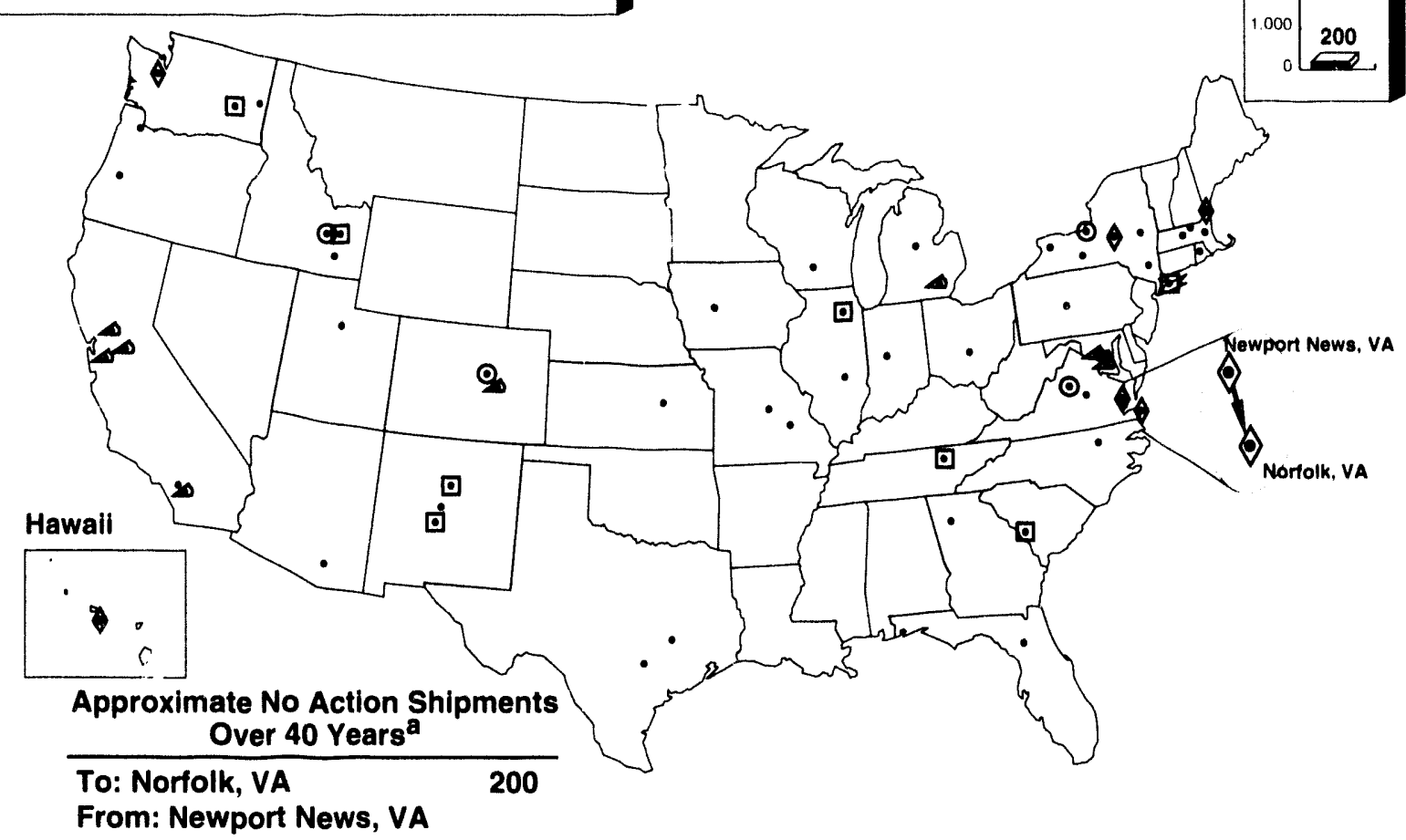

\begin{tabular}{lr}
\multicolumn{2}{c}{$\begin{array}{c}\text { Approximate } 2035 \text { Inventory } \\
\text { (Metric Tons Heavy Metal) }\end{array}$} \\
\hline Hanford & 2,133 \\
Idaho National & \\
Engineering Laboratory & 301 \\
Savannah River Site & 202 \\
Naval Sites & 55 \\
Oak Ridge Reservation & 4 \\
Other & 64 \\
\hline Total & 2,759
\end{tabular}

a. Shipment numbers exclude shipments that

$\frac{\text { State }}{\text { New York }}$

Virginia

Norfolk

Virginia

Pearl Harbor

Hawail

Portsmouth

Maine

Puget Sound

Washington would be made during transition period (see text).

b. Name of shipyard or site.

Figure 3. Spent nuclear fuel distribution for the No Action alternative. 


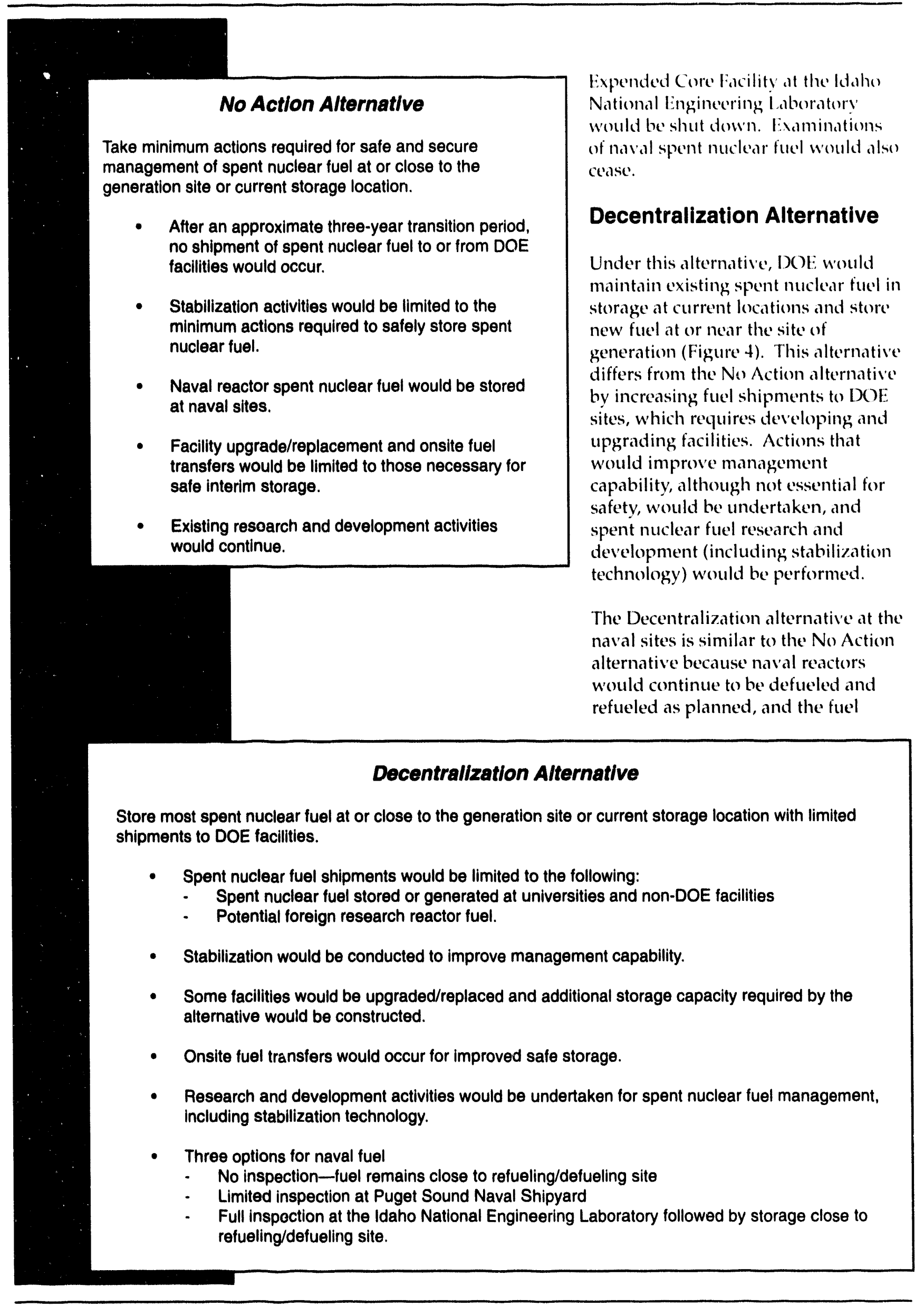




\section{Decentralization - Part 1}

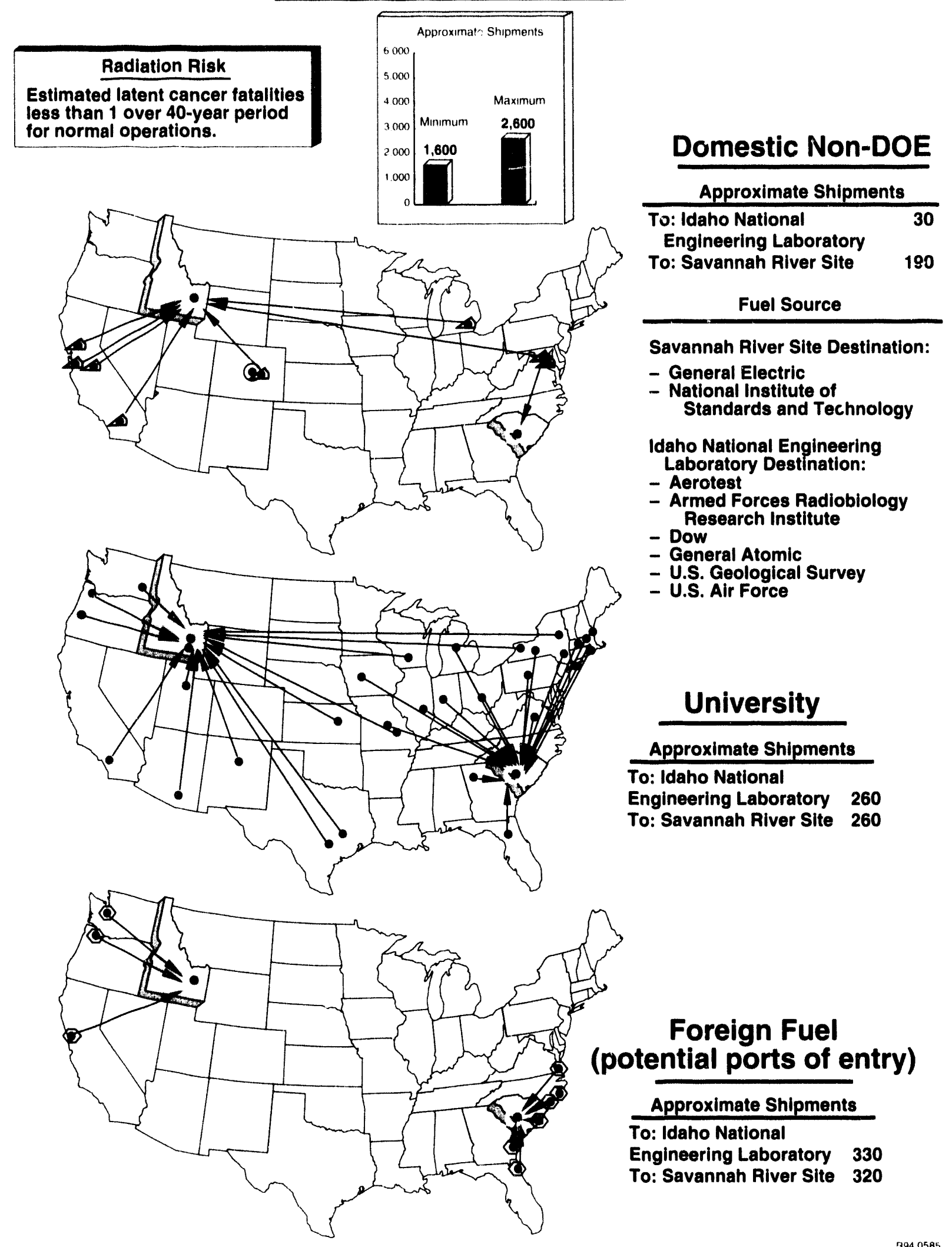

Figure 4. Spent nuclear fuel distribution for the Decentralization alternative. 


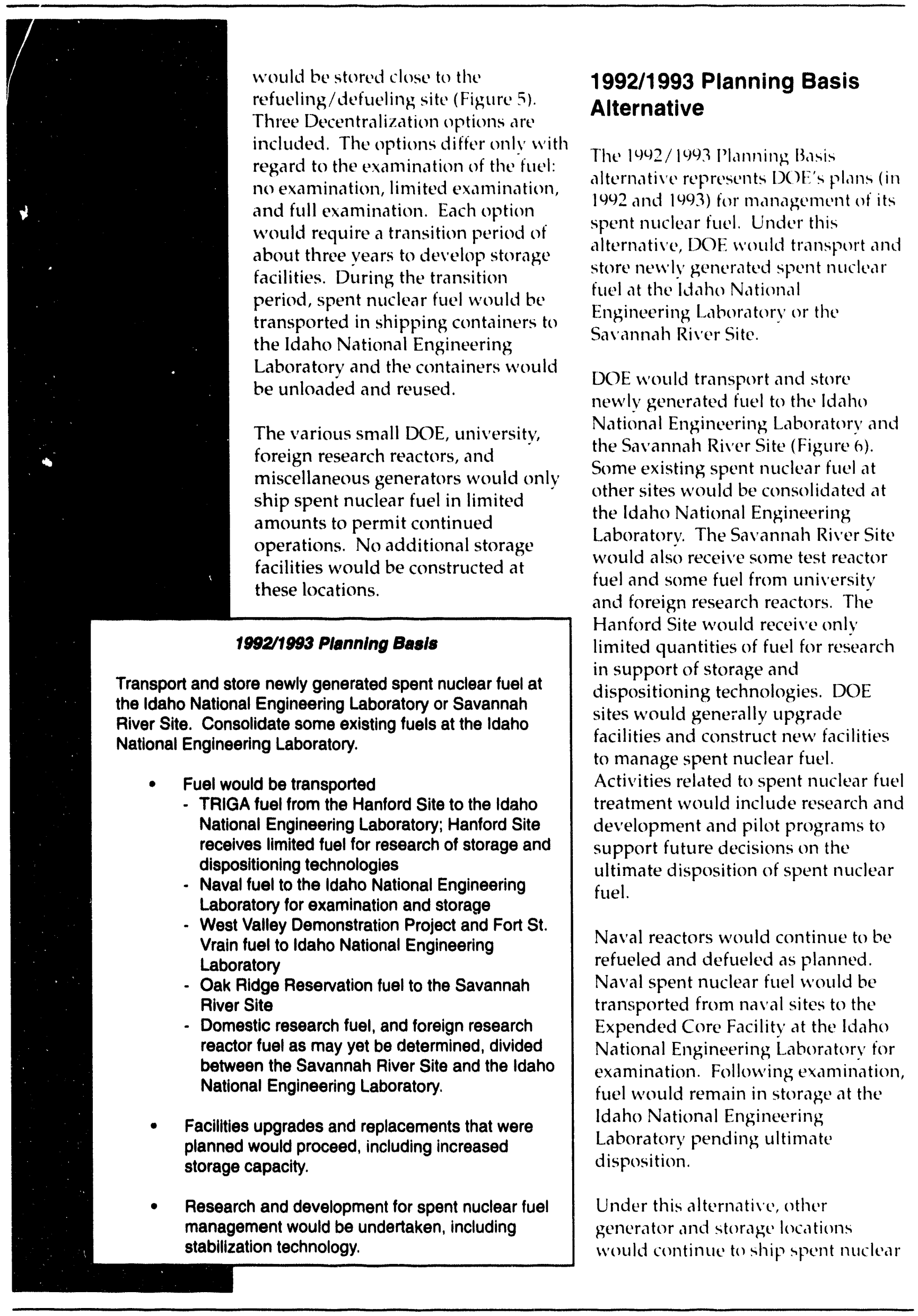

14 Summary 


\section{Decentralization - Part 2}

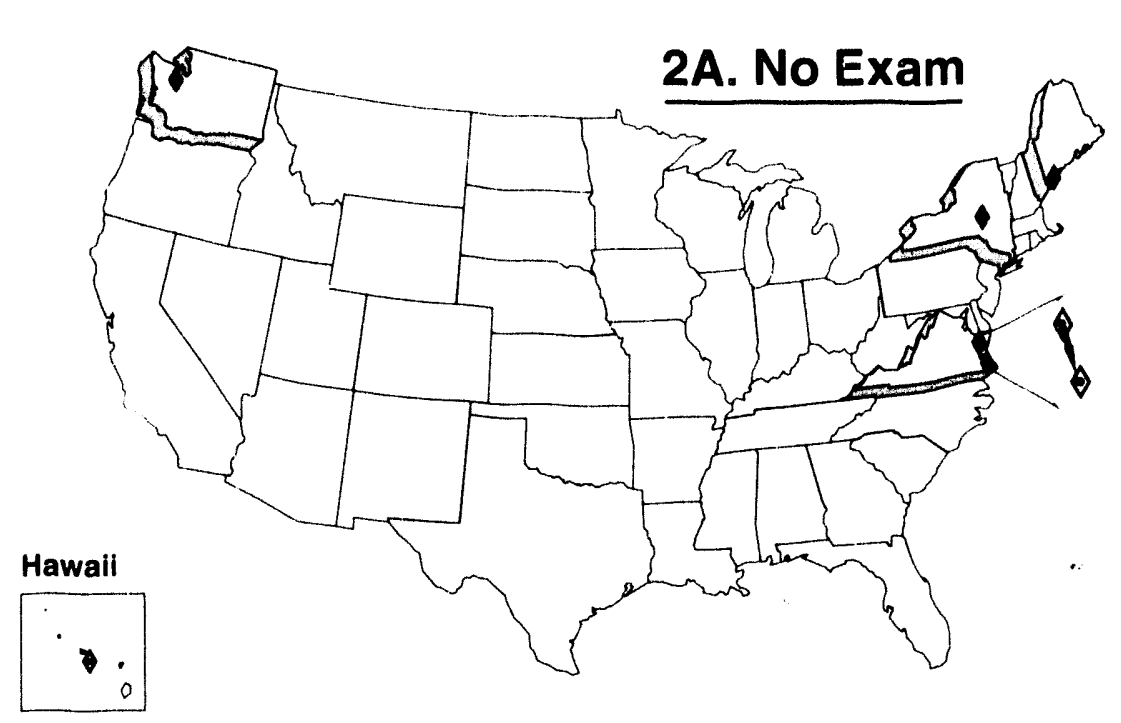

Naval Fuel Shipments ${ }^{a}$

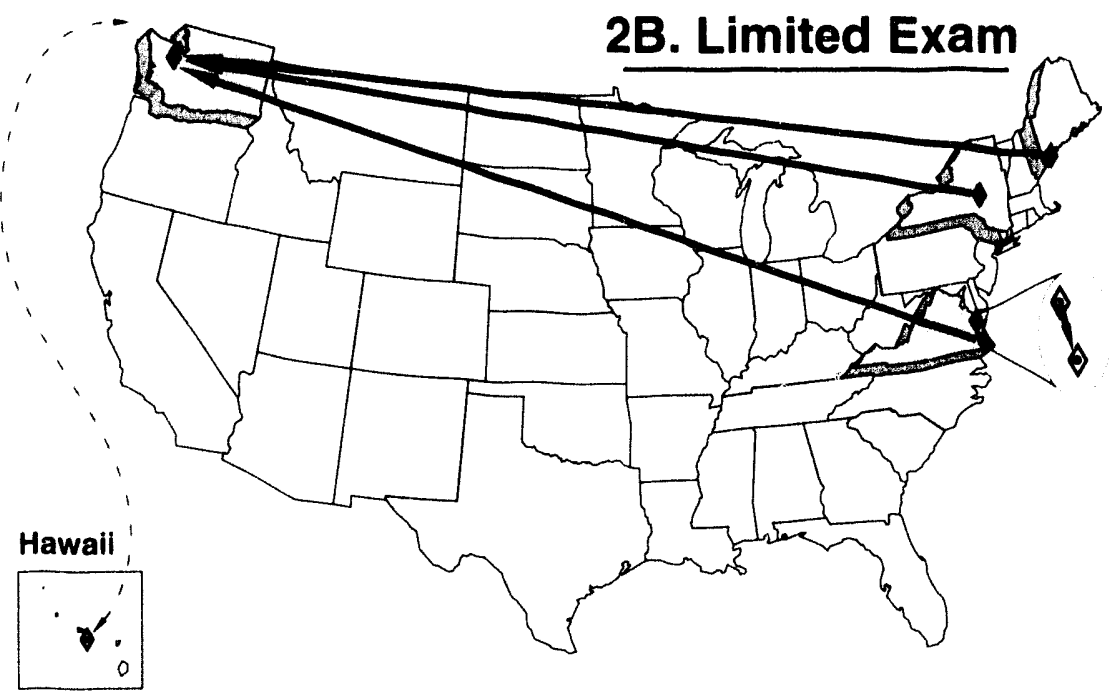

\begin{tabular}{l} 
Approximate Shipments \\
\hline To: Puget Sound, WA \\
To: Norfolk, VA
\end{tabular}

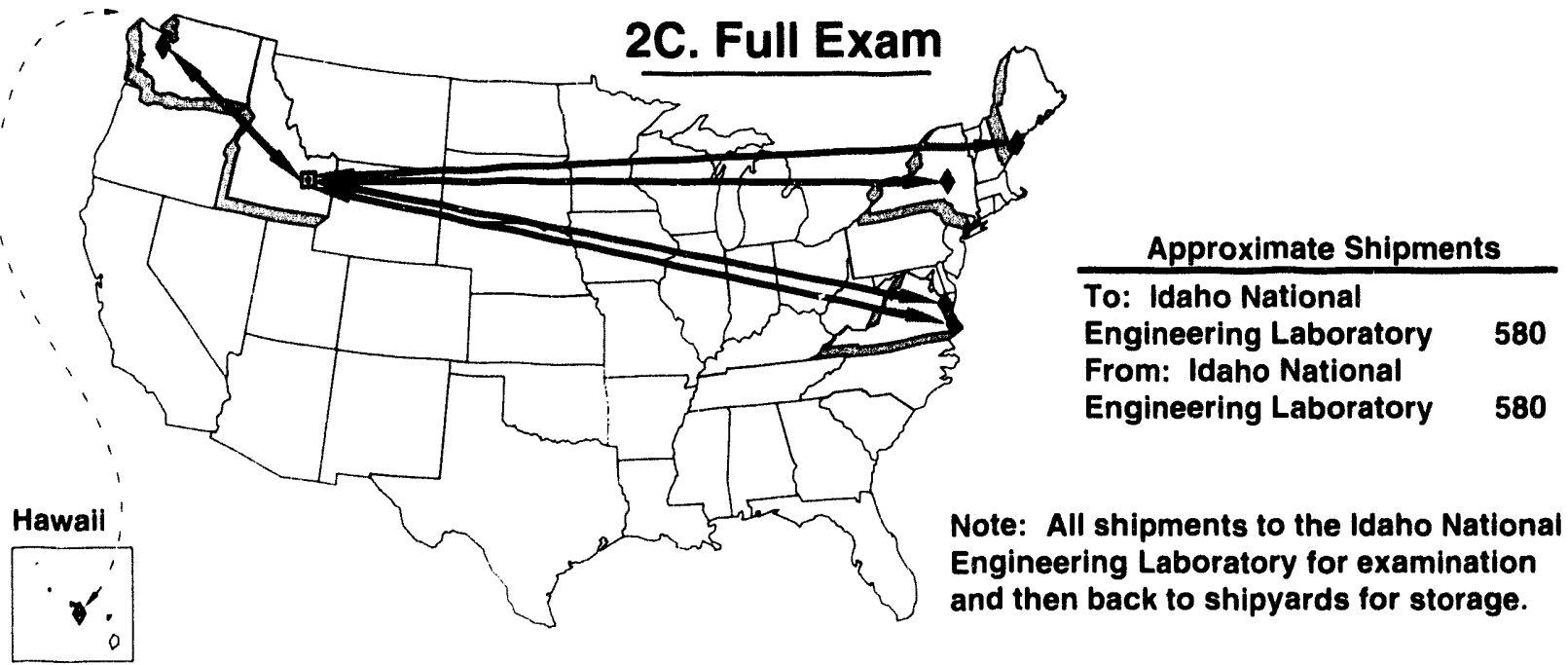

a. Shipment numbers exclude shipments that would be made during transition period (see text).

Figure 5. Spent nuclear fuel distribution for the Decentralization alternative for naval fuel shipments. 


\section{1992 - 1993 Planning Basis}
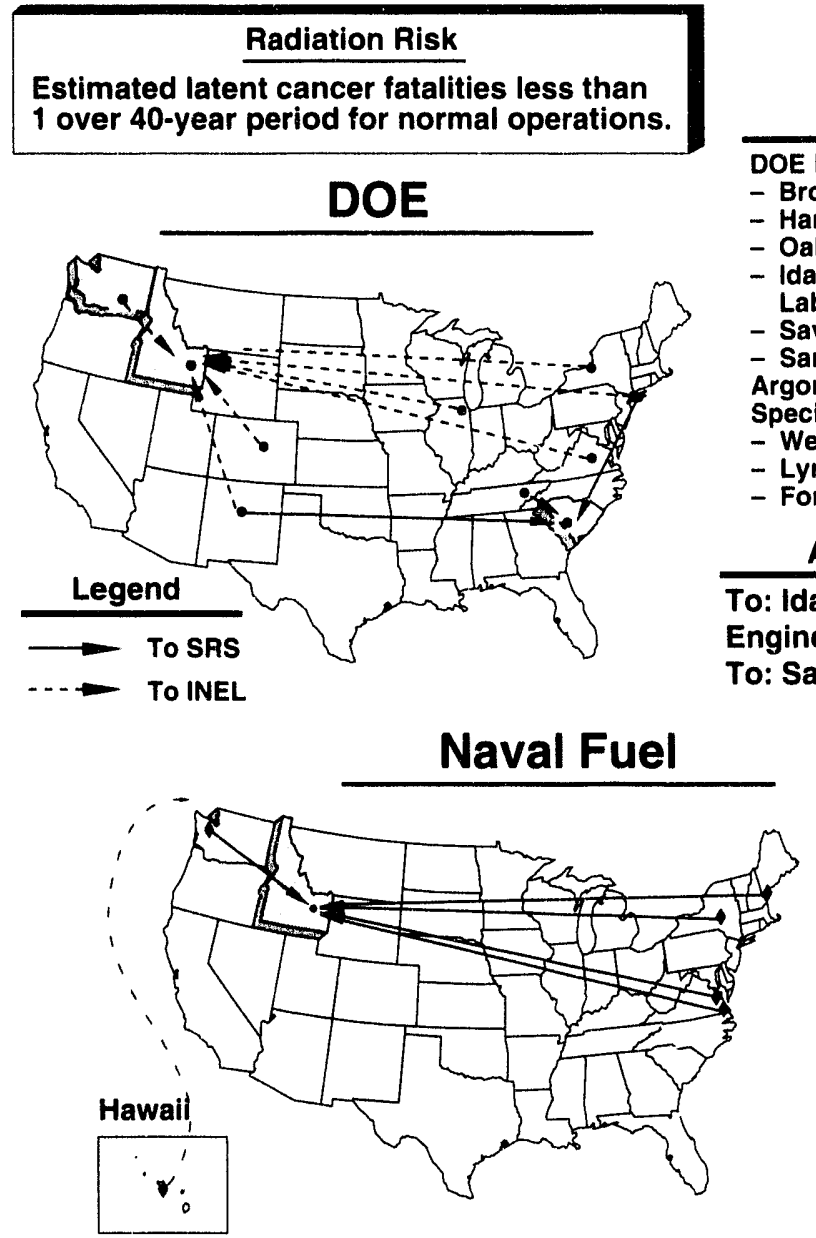

Approximate Shipments

To: INEL

for examination and storage

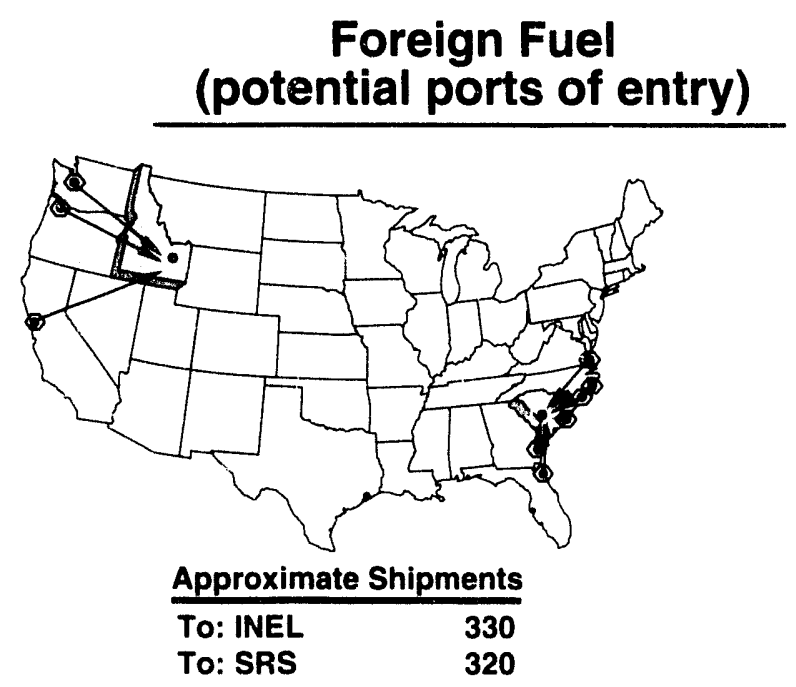

\section{Fuel Source}

DOE Research

- Brookhaven National Laboratory, NY

- Hanford, WA

- Oak Ridge Reservation, TN

- Idaho National Engineering

Laboratory, ID

- Savannah River Site, SC

- Sandia National Laboratories, NM

Argonne National Laboratory-East, IL

Special Case Commercial

- West Valiey, NY

- Lynchburg, VA

- Fort St. Vrain, CO

Approximate Shipments

To: Idaho National

Engineering Laboratory (INEL)

To: Savannah River Site (SRS)
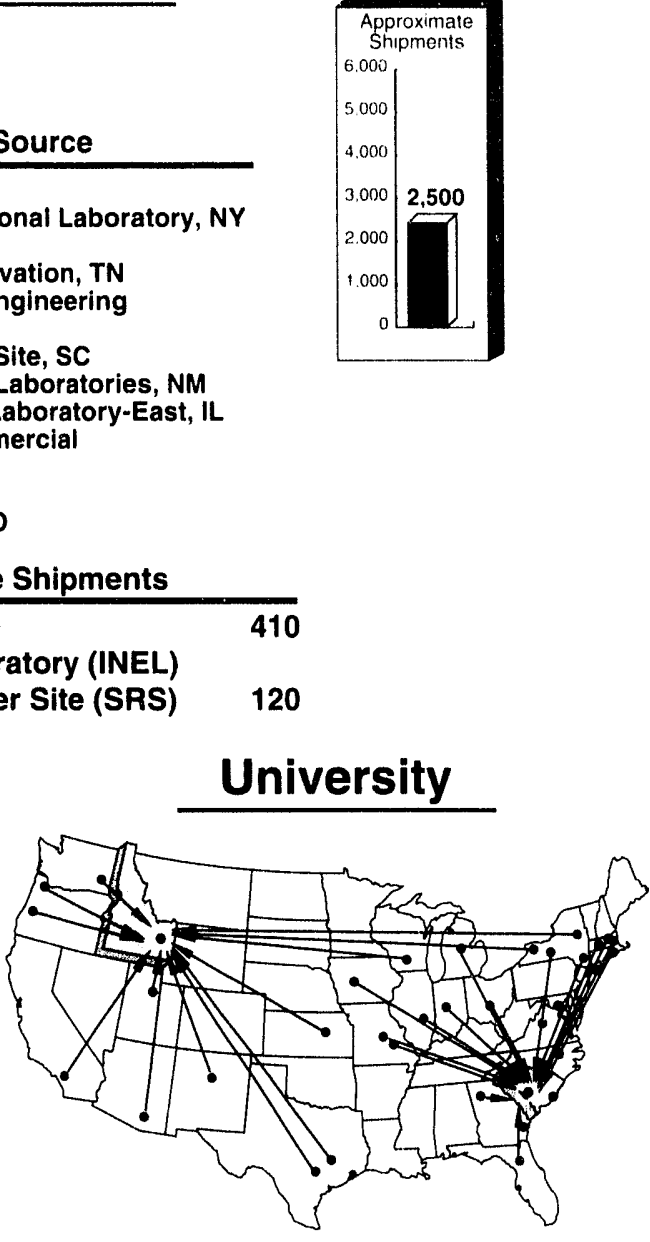

Approximate Shipments

TO: INEL

260

TO: SRS

260

\section{Domestic Non-DOE}

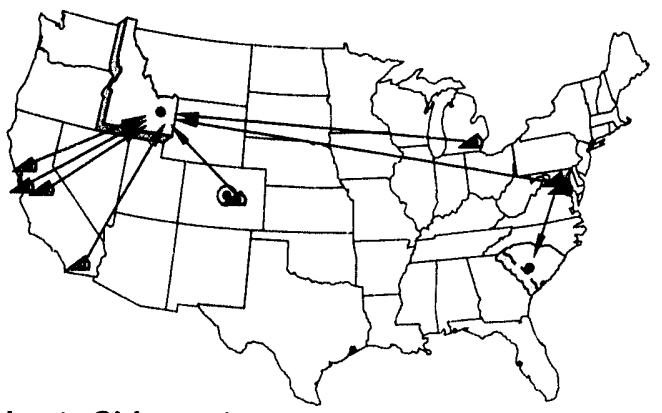

Approximate Shipments

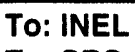

To: SRS

30

190

Figure 6. Spent nuclear fuel distribution for the 1992/1993 Planning Basis alternative. 
fuel to the Idaho National Engineering Laboratory and the Savannah River Site. No additional storage facilities would be constructed at these originating locations.

\section{Regionalization Alternative}

This alternative would require a redistribution of spent nuclear fuel among DOE sites, either on the basis of fuel types (Subalternative A) (Figure 7) or on the basis of geography (Subalternative B) (Figure 8). Regionalization by fuel type
(Subalternative A) would involve the use of either the Idaho National Engineering Laboratory or the Savannah River Site for storage of nondefense production spent nuclear fuel. Existing defense production spent nuclear fuel at the Hanford Site would remain there. Intersite transportation of fuel would depend on the site's existing capabilities to manage specific fuel types with respect to cladding material, physical and chemical composition, fuel condition, ind adequate facilities to handle increased quantities of fuel. Naval fuel would be transported to

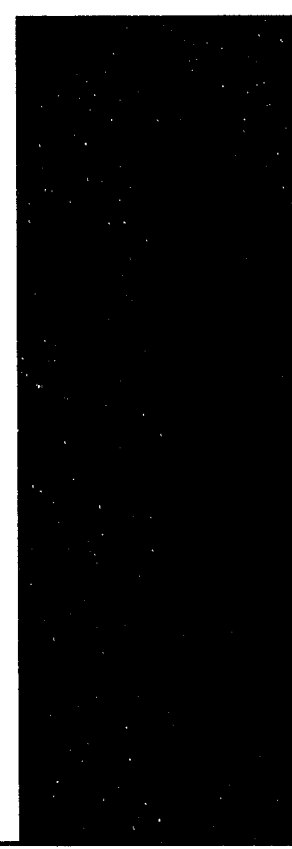

\section{Regionalization}

Regionalization Subalternative A: Distribute existing and projected spent nuclear fuel among DOE sites based primarily on fuel type.

- Naval fuel would be shipped to, examined, and stored at the Idaho National Engineering Laboratory.

- $\quad$ Aluminum-clad fuel shipped to the Savannah River Site; TRIGA and non-aluminum fuel to the Idaho National Engineering Laboratory; retain defense production fuel at the Hanford Site.

- Stabilization would be performed at the shipping site where required before transportation. Additional stabilization would be performed at the regional site.

- Facilities required to support spent nuclear fuel management would be upgraded or built as necessary.

- Research and development for spent nuclear fuel management would be undertaken, including stabilization technology.

Regionalization Subalternative B: Distribute existing and projected spent nuclear fuel between an Eastern Regional Site (either Oak Ridge Reservation or Savannah River Site) and a Western Regional Site (either Hanford Site, Idaho National Engineering Laboratory, or Nevada Test Site).

- The Eastern Regional Site would receive fuel from east of the Mississippi River and the Western Regional Site would receive fuel from west of the Mississippi River.

- Naval fuel would be shipped to, examined, and stored at either the Western Regional Site or the Eastern Regional Site.

- $\quad$ Stabilization would be performed at the shipping site where required for transportation. Additional stabilization would be performed at the regional site.

- Facilities required to support spent nuclear fuel management would be upgraded or built as necessary.

- Research and development would be undertaken for spent nuclear fuel management, including stabilization techriology. 


\section{DOE - Regionalization (by Fuel Type)}

\section{Subalternative A}
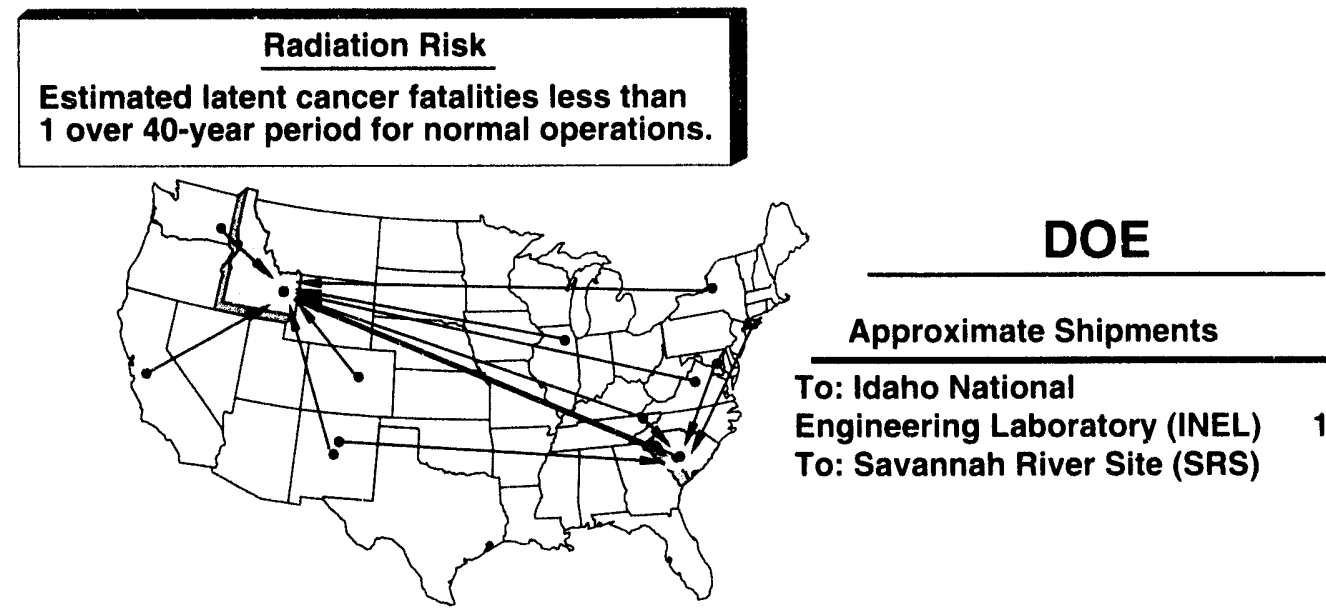

Approximate Shipments

\begin{tabular}{lr}
\hline To: Idaho National & \\
Engineering Laboratory (INEL) & 1,000 \\
To: Savannah River Site (SRS) & 280
\end{tabular}

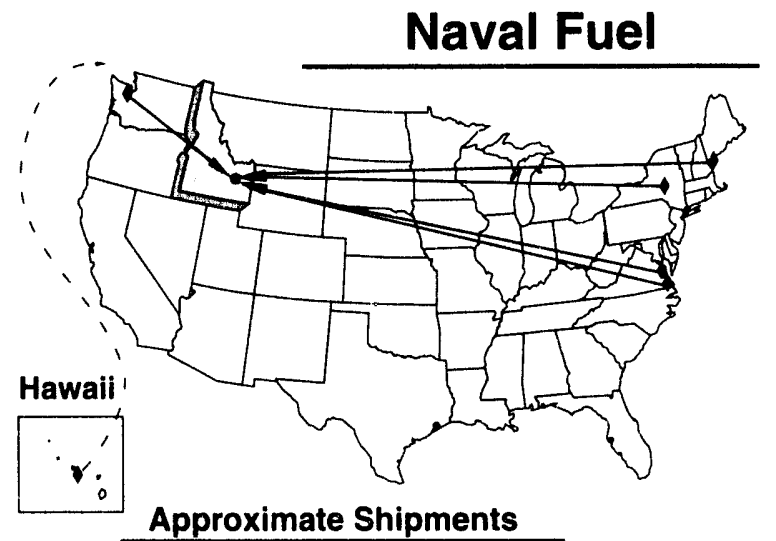

To: INIEL for examination and storage

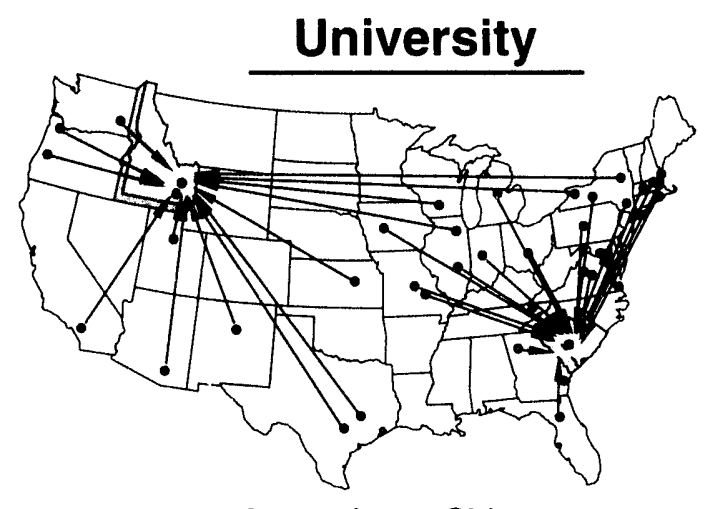

Approximate Shipments

To: INEL 120

To: SRS $\quad 400$
Foreign Fuel (potential ports of entry)

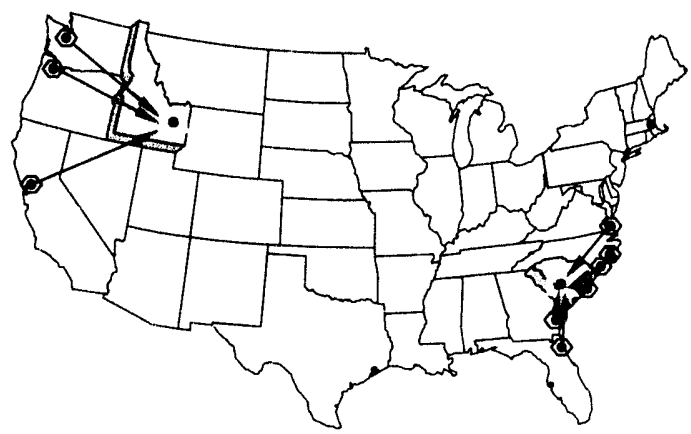

Approximate Shipments

To: INEL $\quad 70$

To: SRS $\quad 580$

\section{Domestic Non-DOE}

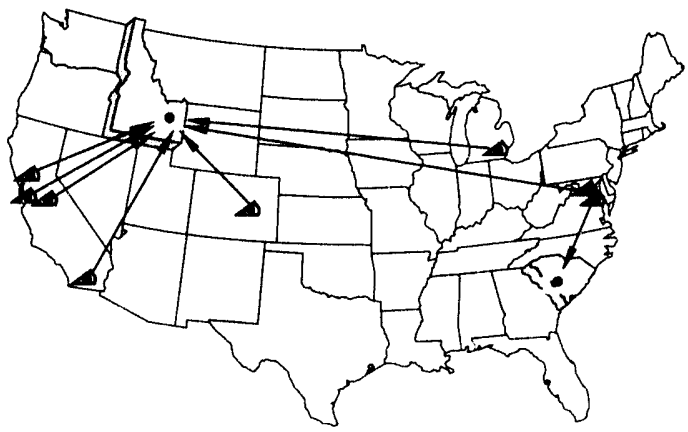

Approximate Shipments

To: INEL 30

To: SRS 190

Figure 7. Spent nuclear fuel distribution for Regionalization Subalternative A. 


\section{DOE - Regionalization (by Geography) - Part 1}

Subalternative B

East

\section{Radiation Risk}

Estimated latent cancer fatalities less than 1 over 40 -year period for normal operations.

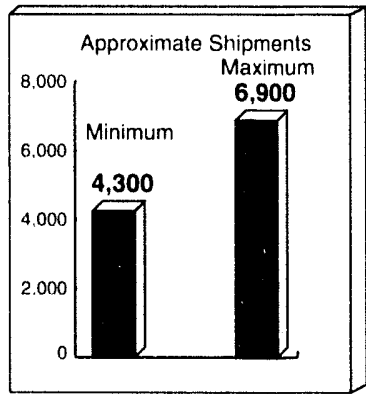

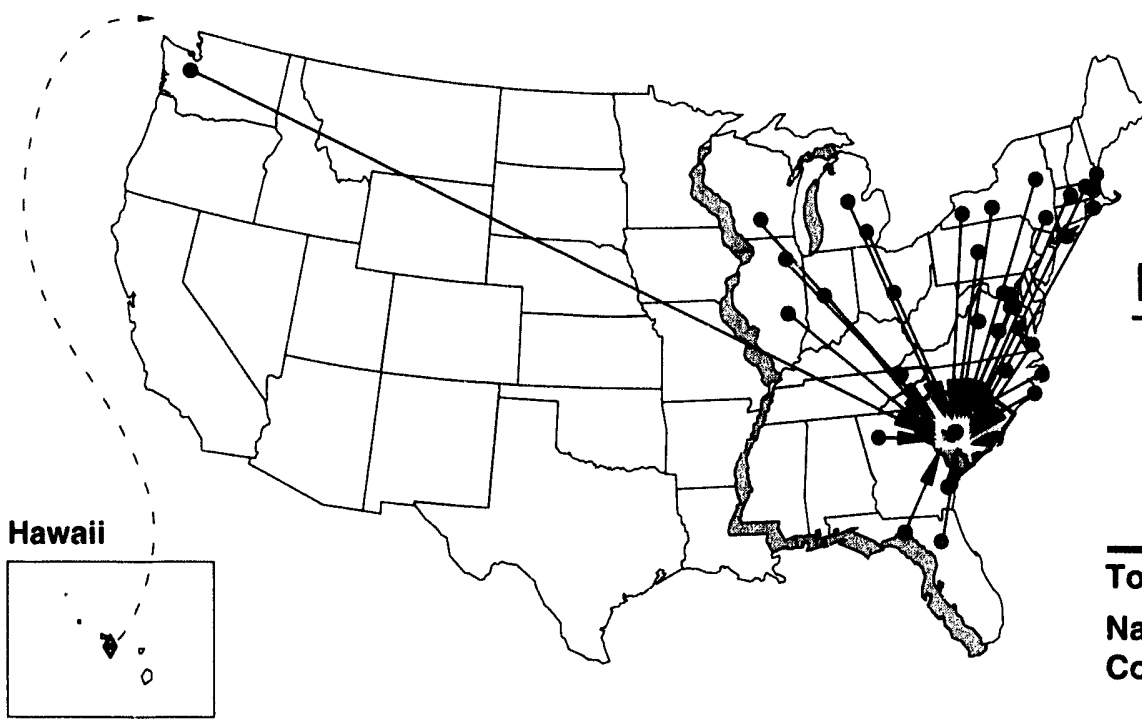

\section{DOE - Regionalization}

Subalternative B (1 East - SRS)

Approximate Shipments ${ }^{a}$

To: Savannah River Site (SRS) 1,200

Naval shipments if Expended Core Facility at SRS

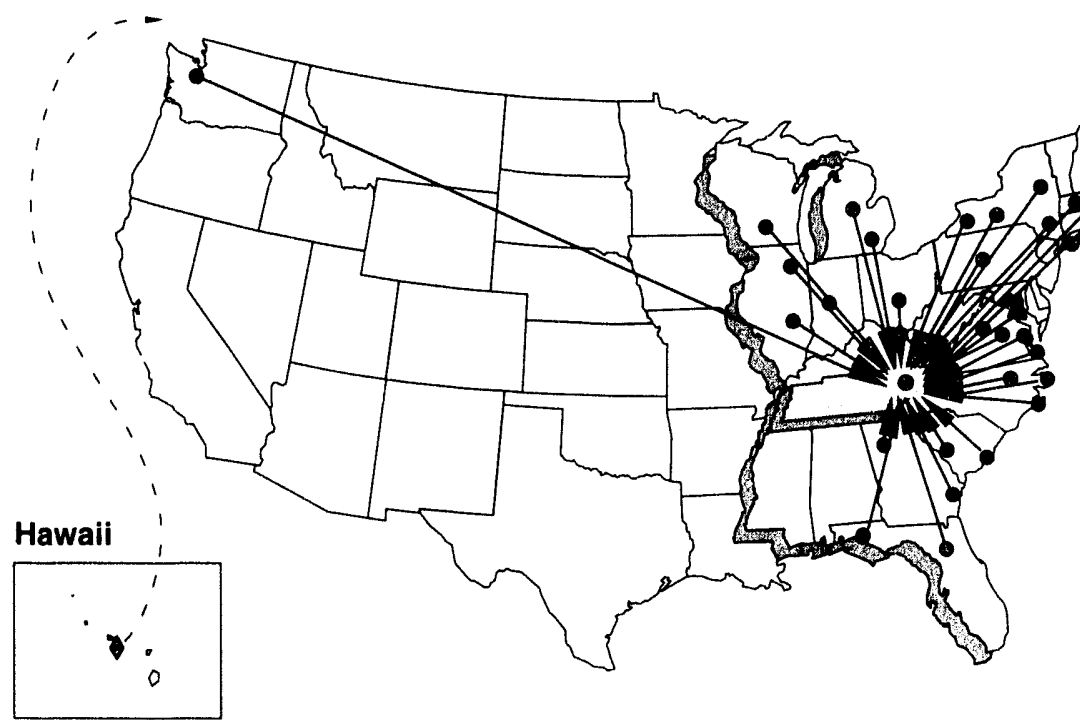

\section{DOE - Regionalization Subalternative B (2 East - ORR)}

\section{Approximate Shipments ${ }^{a}$}

To: Oak Ridge Reservation (ORR) 2,000

Naval shipments if Expended

Core Facility at ORR

580

a. Shipment numbers exc/ude shipments that would be made during transition period (see text).

Figure 8. Spent nuclear fuel distribution for Regionalization Subalternative B. 


\section{DOE - Regionalization (by Geography) - Part 2}

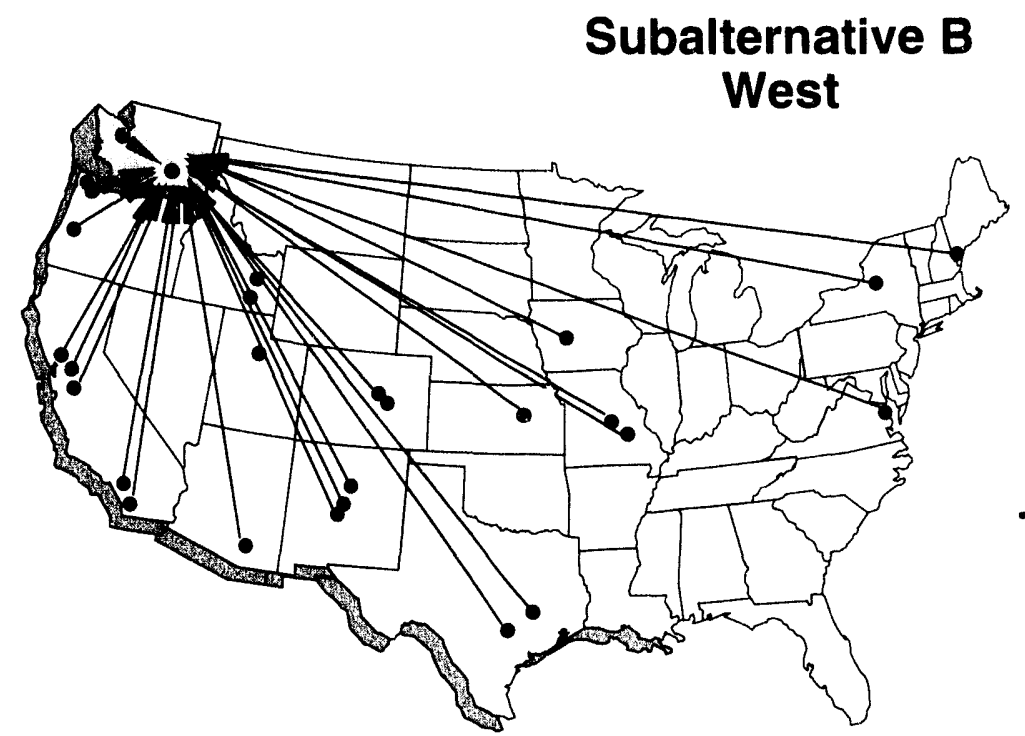

DOE - Regionalization

Subalternative B (1 West - Hanford)

Approximate Shipments ${ }^{a}$

To: Hanford

2,600

Naval shipments

if Expended Core Facility at Hanford

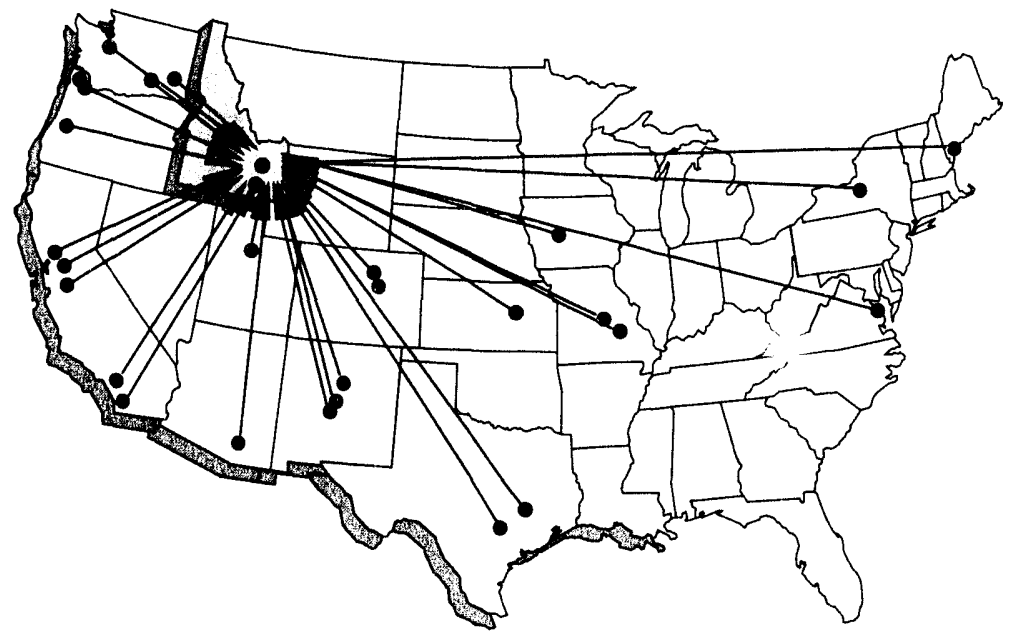

DOE - Regionalization Subalternative B (2 West - INEL)

\section{Approximate Shipments}

To: Idaho National

Engineering Laboratory $\quad 2,400$ (INEL)

Naval shipments

if Expended Core Facility at the INEL

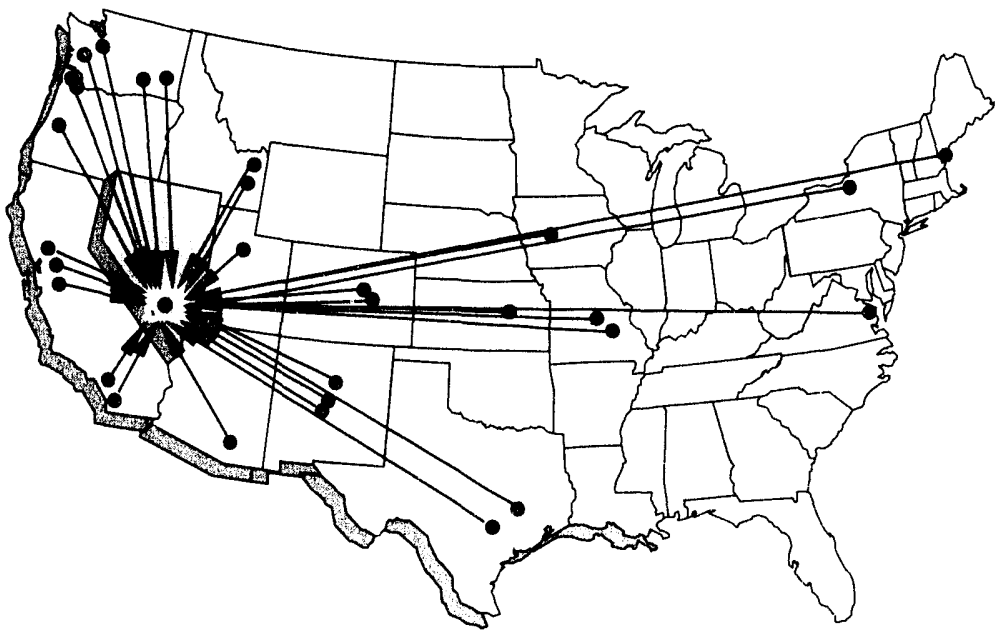

\section{DOE - Regionalization Subalternative B (3 West - NTS)}

Approximate Shipments ${ }^{a}$ To: Nevada Test Site (NTS) $\quad \mathbf{4 , 4 0 0}$

Naval shipments if Expended Core Facility at NTS

a. Shipment numbers exclude shipments that would be made during transition period (see text).

Figure 8. (continued). 
the Expended Core Facility at the Idaho National Engineering Laboratory for examination. Following examination, fuel would remain in storage at the Idaho National Engineering Laboratory. Facility upgrades, replacements, and additions would be undertaken to the extent required, including research and development activities.

Regionalization by geography (Subalternative B) would involve consolidation of spent nuclear fuel from the eastern United States at the Eastern Regional Site (Oak Ridge Reservation or Savannah River Site) and consolidation of fuel from the western United States at one of the Western Regional Sites (Hanford Site, Idaho National Engineering Laboratory, or Nevada Test Site"). Naval fuel would be shipped to, examined, and stored at either the Eastern or the Western Regional Site. Subalternative B has 10 options, based on the combination of sites selected as the Eastern and Western Regional Sites, and the placement of the Expended Core Facility at either of the sites. There are three potential Western and two potential Eastern Regional Sites that could be paired, with either supporting the Expended Core Facility. However, neither of the two possible combinations that include the Idaho National Engineering Laboratory as the Western Regional Site would consider moving the Expended Core Facility to the eastern site because of the estimated $\$ 1$ billion cost of construction. Facility upgrades, replacements, and additions would be undertaken to the extent required, including research and development.

Under this alternative, other generator and storage locations would continue to ship spent nuclear fuel to the Idaho National Engineering Laboratory and the Savannah River Site. The exact destination of fuels would vary, depending on the fuel type under Regionalization Subalternative A and on the generator/storage location under Regionalization Subalternative B.

\section{Centralization Alternative}

Under the Centralization alternative, all spent nuclear fuel that DOE is obligated to manage would be transported to one DOE site (Figure 9). Candidate sites include the Hanford Site (Option A), Idaho National Engineering Laboratory (Option B), Savannah River Site (Option C), Oak Ridge Reservation (Option D), and Nevada Test Site (Option E). New facilities would be built at the Centralization site to accommodate the increased inventories. Some spent nuclear fuel would require stabilization before shipment. All spent nuclear fuel facilities at the shipping sites would then be closed. Activities related to stabilization of fuel, including research and development and pilot programs, would also be centralized at this same site.

Shipment of naval spent nuclear fuel to the Idaho National Engineering Laboratory would continue only until storage and examination facilities are constructed at the central site. For consolidation at sites other than the Idaho National Engineering Laboratory, a new facility with capabilities comparable to the Expended Core Facility at the Idaho National Engineering Laboratory would be constructed.

All spent nuclear fuel from the other generator and storage sites would be shipped to the selected centralized DOE facility. 


\section{Centralization}
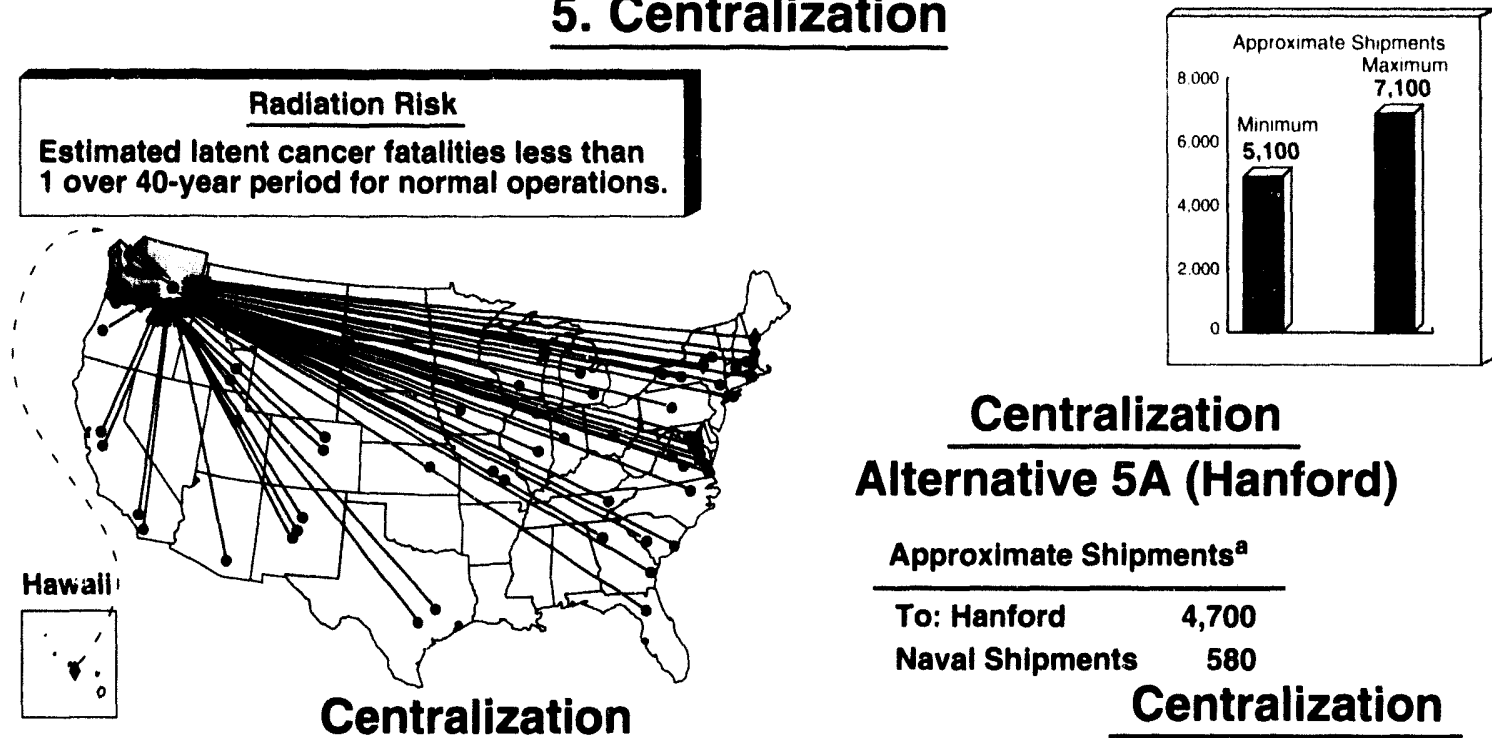

\section{Centralization Alternative 5A (Hanford)}

\section{Approximate Shipments ${ }^{a}$ \\ To: Hanford $\quad 4,700$ \\ Naval Shipments $\quad 580$}

Centralization

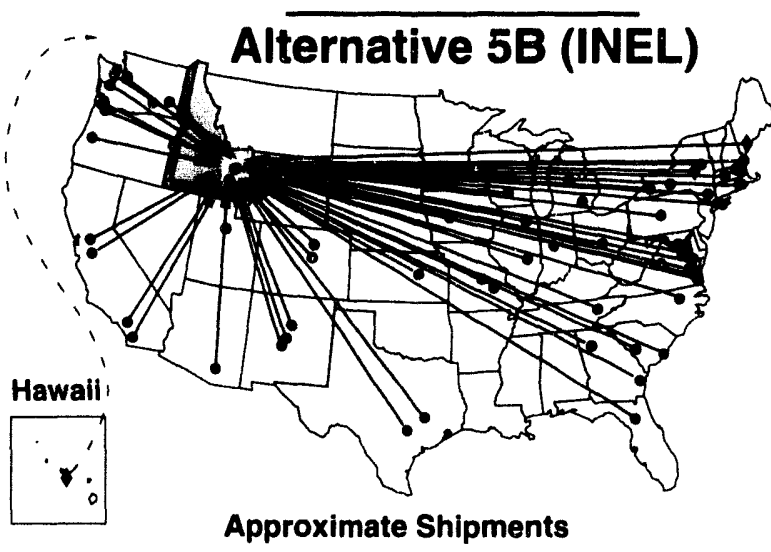

To: Idaho National Engineering Laboratory (INEL) Naval Shipments

Centralization
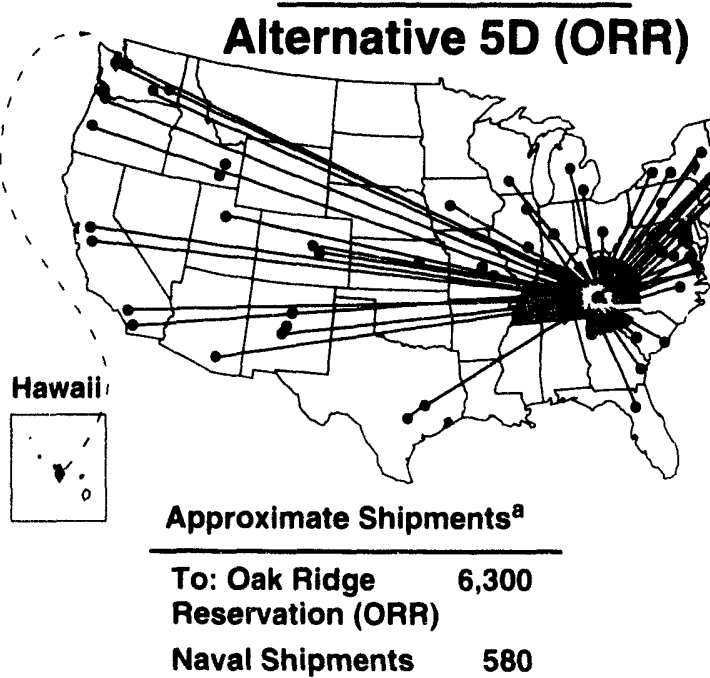

Alternative 5C (SRS)

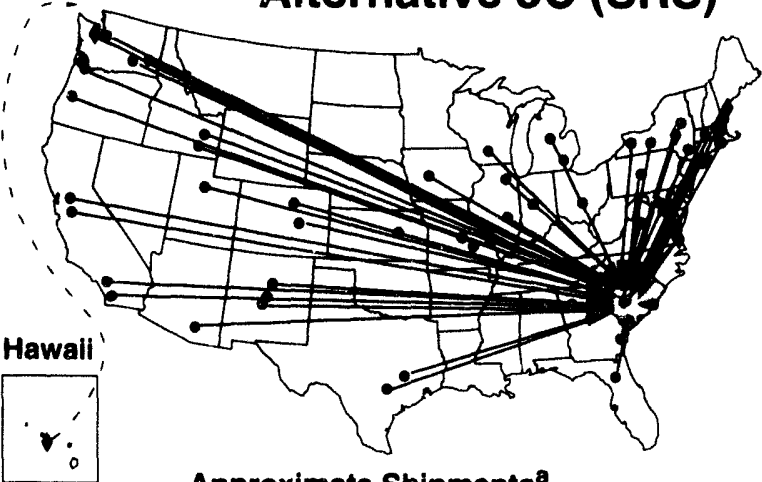

Approximate Shipments ${ }^{a}$

To: Savannah $\quad \mathbf{5 , 6 0 0}$

River Site (SRS)

Naval Shipments $\quad 580$

\section{Centralization}

Alternative 5E (NTS)

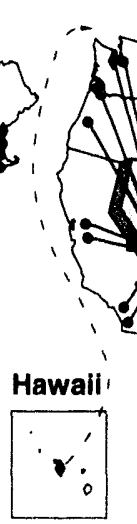

'v'

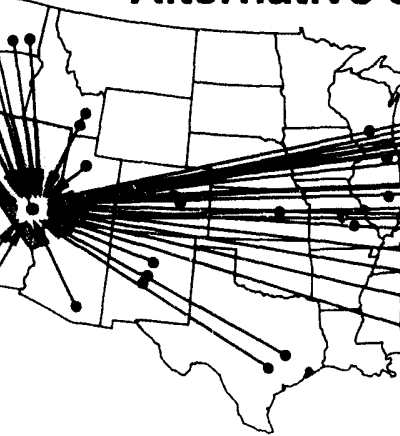

Approximate Shipments ${ }^{a}$

To: Nevada

6,500

Test Site (NTS)

Naval Shipments

580

a. Shipment numbers exclude shipments that would be made during transition period (see text).

Figure 9. Spent nuclear fuel distribution for the Centralization alternative. 
stimates in the EIS of potential environmental consequences resulting from programmatic (DOEwide) alternatives are based on conservative assumptions (that is, with a tendency to overestimate). Analytical approaches are designed to provide estimates of the maximum reasonably foreseeable consequences. As indicated in the EIS, the environmental consequences of the five spent nuclear fuel management alternatives would be small or negligible. For example, analyses of air quality, water quality, and land use for each alternative showed little or no impact. The details of these examinations are discussed in Chapter 5 of Volume 1. The comparison of alternatives in this Summary, therefore, concentrates on (a) the areas in which the public has expressed considerable interest and (b) programmatic factors important to DOE decisionmaking. The following factors were selected for comparison:

- Number of shipments among sites

- Public and worker health effects

- Spent nuclear fuel-related employment

- Generation of radioactive waste

- Impact on DOE or Navy missions

- Cost of implementation.

\section{Number of Shipments}

Figure 10 and Table 1 show the number of offsite shipments that would occur under each alternative. Figure 10 quantifies shipments of test specimens, as well as fuel elements. Shipments of naval test specimens are included because of their contribution to cumulative impacts of naval spent nuclear fuel transportation. The No Action alternative would involve only a limited number of naval spent nuclear fuel shipments (about 200). The Decentralization alternative,
1992/1993 Planning Basis alternative, and Regionalization Subalternative $A$ mostly involve shipments from the smaller reactor and storage sites and the naval sites to DOE sites. These shipments would range in number from approximately 1,600 shipments under Decentralization Options A or B to approximately 3,300 under Regionalization Subalternative A. Decentralization Option $C$ and the 1992/1993 Planning Basis each would involve approximately 2,500 shipments over the 40-year period. For the Centralization alternative and Regionalization Subalternative B, spent nuclear fuel would be shipped to one or two sites, respectively. For Regionalization Subalternative B, the number of shipments would range from approximately 4,300 for the Idaho National Engineering Laboratory/Savannah River Site to about 6,900 for the Nevada Test Site/ Oak Ridge Reservation. For the Centralization alternative, the number of shipments would range from approximately 5,100 for Option B at the Idaho National Engineering Laboratory to 7,000 for Option E at the Nevada Test Site.

\section{Public and Worker Health Effects}

Spent nuclear fuel management activities would result in radiation exposures to the workers and the public from facility operations, transportation activities, and accidents. Radiation exposures also occur from natural sources such as cosmic radiation and from artificial sources such as chest $\mathrm{X}$-rays.

The effects of radiation exposure on humans (and the environment) depend on (a) the kind of radiation received, (b) the total amount of radiation received (the rate of exposure times the length of exposure), and (c) the part(s) of the body exposed. Radiation can cause a variety of health effects in people. The

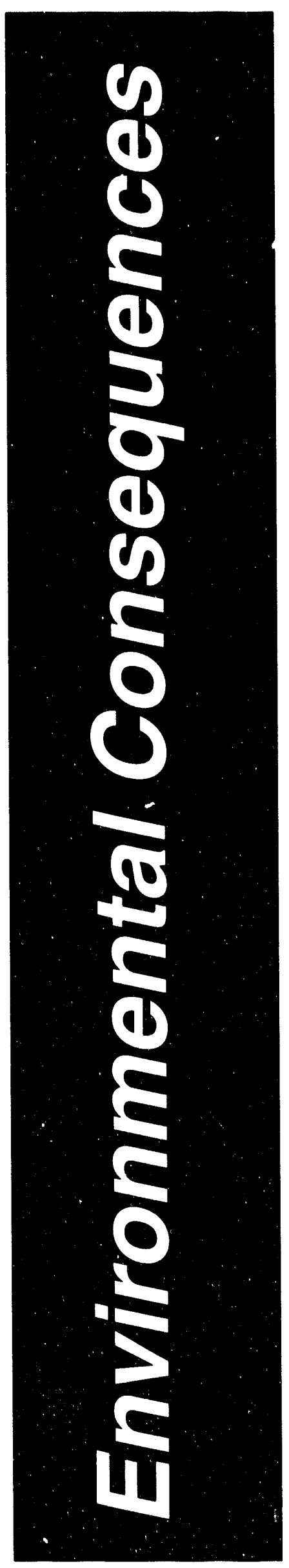


7,000

6,000

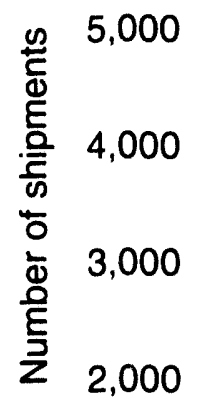

1,000

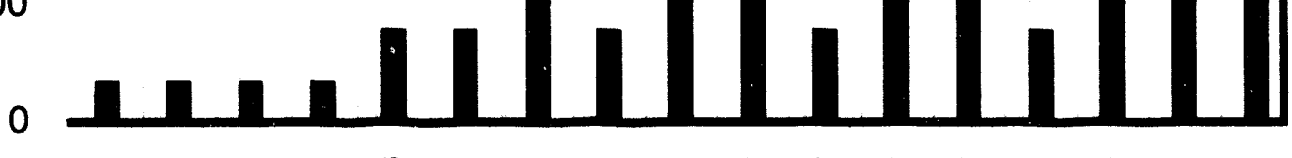

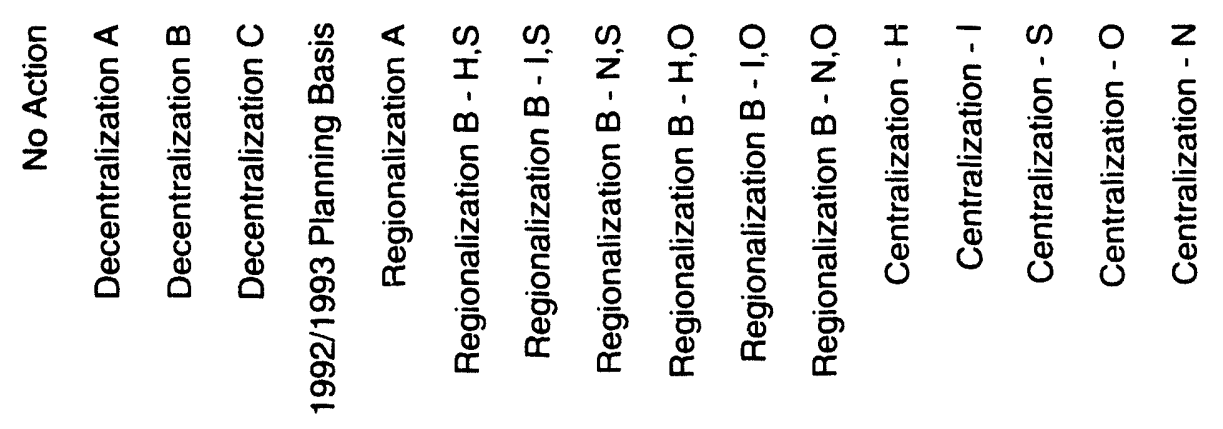

Key:

Decentralization A: No examination of Naval fuels

Decentralization B: Limited examination of Naval fuels at Puget Sound Naval Shipyard

Decentralization C: Full examination of Naval fuels at Idaho National Engineering Laboratory with SNF stored at Naval sites

Regionalization A: Regionalization by fuel type

Regionalization B: Regionalization by location

$\mathrm{H}$ : Hanford Site

Site initials: I: Idaho National Engineering Laboratory

Spent fuel

S: Savannah River Site

O: Oak Ridge Reservation

N: Nevada Test Site

Test specimens $^{a}$

a. Test specimens are small quantity fuel samples shipped for laboratory analysis

Figure 10. Number of spent nuclear fuel and test specimen shipments between the years 1995 and 2035. 
Table 1. Number of spent nuclear fuel shipments by alternative.

\begin{tabular}{|c|c|c|c|}
\hline \multirow[b]{2}{*}{ Alternative } & & \multicolumn{2}{|c|}{ Number of shipments } \\
\hline & & Spent fuel shipments ${ }^{a}$ & $\begin{array}{c}\text { Test } \\
\text { specimen shipments }\end{array}$ \\
\hline \multicolumn{2}{|l|}{ No Action } & 200 & 320 \\
\hline $\begin{array}{r}\text { Decentralize } \\
\text { A } \\
\text { B } \\
\text { C }\end{array}$ & tion & $\begin{array}{l}1,600 \\
1,600 \\
2,500\end{array}$ & $\begin{array}{l}320 \\
320 \\
320\end{array}$ \\
\hline \multicolumn{2}{|c|}{ 1992/1993 Planning Basis } & 2.500 & 760 \\
\hline \multicolumn{4}{|c|}{ Regionalization B } \\
\hline $\begin{array}{l}\mathrm{Ha} \\
\text { Ida } \\
\mathrm{Ne} \\
\mathrm{Ha} \\
\mathrm{Ida} \\
\mathrm{Ne}\end{array}$ & $\begin{array}{l}\text { ford Site/Savannah River Site } \\
\text { to National Engineering } \\
\text { aboratory/Savannah River Site } \\
\text { ada Test Site/Savannah River Site } \\
\text { ford Site/Oak Ridge Reservation } \\
\text { o National Engineering } \\
\text { aboratory/Oak Ridge Reservation } \\
\text { ada Test Site/Oak Ridge Reservation }\end{array}$ & $\begin{array}{l}4,500 \\
4,300 \\
6,200 \\
5,200 \\
5,000 \\
6,900\end{array}$ & $\begin{array}{r}1,750 \\
760 \\
1,750 \\
1,750 \\
760 \\
1,750\end{array}$ \\
\hline \multicolumn{4}{|c|}{ Centralization } \\
\hline $\begin{array}{l}A \\
B \\
C \\
D \\
E\end{array}$ & $\begin{array}{l}\text { Hanford Site } \\
\text { Idaho National Engineering Laboratory } \\
\text { Savannah River Site } \\
\text { Oak Ridge Reservation } \\
\text { Nevada Test Site }\end{array}$ & $\begin{array}{l}5,300 \\
5,100 \\
6,200 \\
6,900 \\
7,000\end{array}$ & $\begin{array}{r}1,750 \\
760 \\
1,750 \\
1,750 \\
1,750\end{array}$ \\
\hline \multicolumn{4}{|c|}{$\begin{array}{l}\text { a. Naval spent nuclear fuel shipments would be by rail, and DOE spent nuclear fuel shipments } \\
\text { would be by truck. } \\
\text { b. Test specimens would be shipped by truck. }\end{array}$} \\
\hline
\end{tabular}

most significant health effect to describe the consequences of public and worker radiation exposures is "latent cancer fatality." It is referred to as "latent" because the cancer may take many years to develop and for death to occur.

Under all alternatives (over a 40-year period), the estimated number of latent cancer fatalities from the normal operation of DOE spent nuclear fuel management facilities would range from approximately zero to about two latent cancer fatalities, or about 0.04 latent cancer fatalities per year (Figure 11). In general, the greatest radiation exposure from normal spent nuclear fuel site activities and incident-free transportation results when large quantities of spent nuclear fuel are transported among sites, such as under Regionalization

Subalternative B or the Centralization alternative. Under incident-free transportation, the estimated total latent cancer fatalities are less than two for all alternatives, with the highest estimates being those associated with the Centralization options. This reflects the higher number of shipments associated with these options.

The risk of latent cancer facilities associated with facility accidents is small across all the alternatives, as shown in Figure 12. The evaluated facility accident scenario with the highest risk (breach of a fuel assembly for the Centralization alternative at the Savannah River Site) would result in an estimated 0.0072 latent cancer fatality per year (one latent fatal cancer in 14 () years).

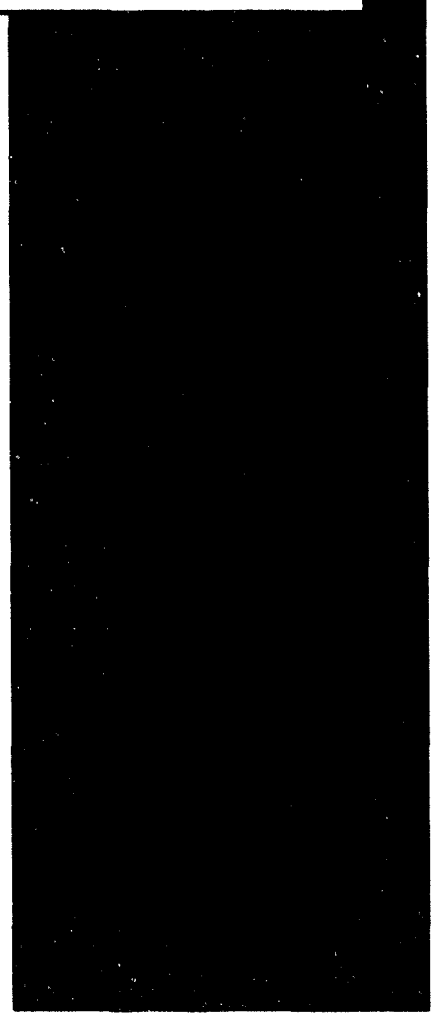




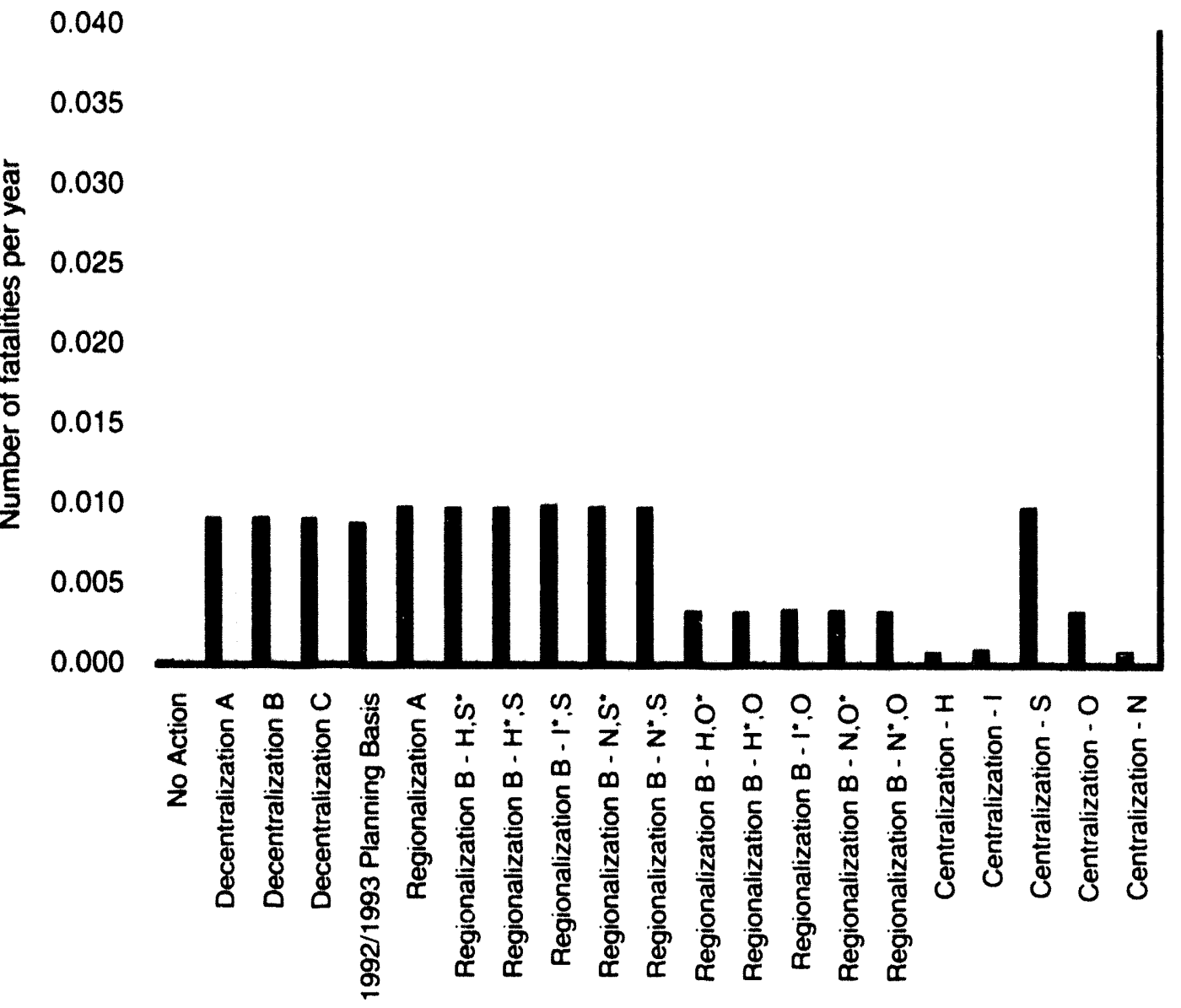

Key:

Decentralization A: No examination of Naval fuels

Decentralization B: Limited examination of Naval fuels at Puget Sound Naval Shipyard

Decentralization C: Full examination of Naval fuels at Idaho National Engineering Laboratory with SNF stored at Naval sites

Regionalization A: Regionalization by fuel type

Regionalization B: Regionalization by location

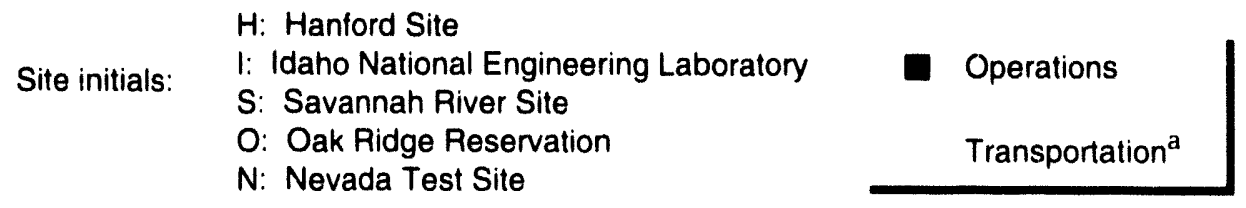

- Location of Expenced Core Facility

a. Total fatalities are the sum of the estimated number of radiation-related latent cancer fatalities for workers and the general population plus the estimated number of nonradiological fatalities from vehicular emissions.

Figure 11. Maximum estimated latent cancer fatalities per year in the general population from normal spent nuclear fuel site operations and total fatalities from incident-free transportation. 


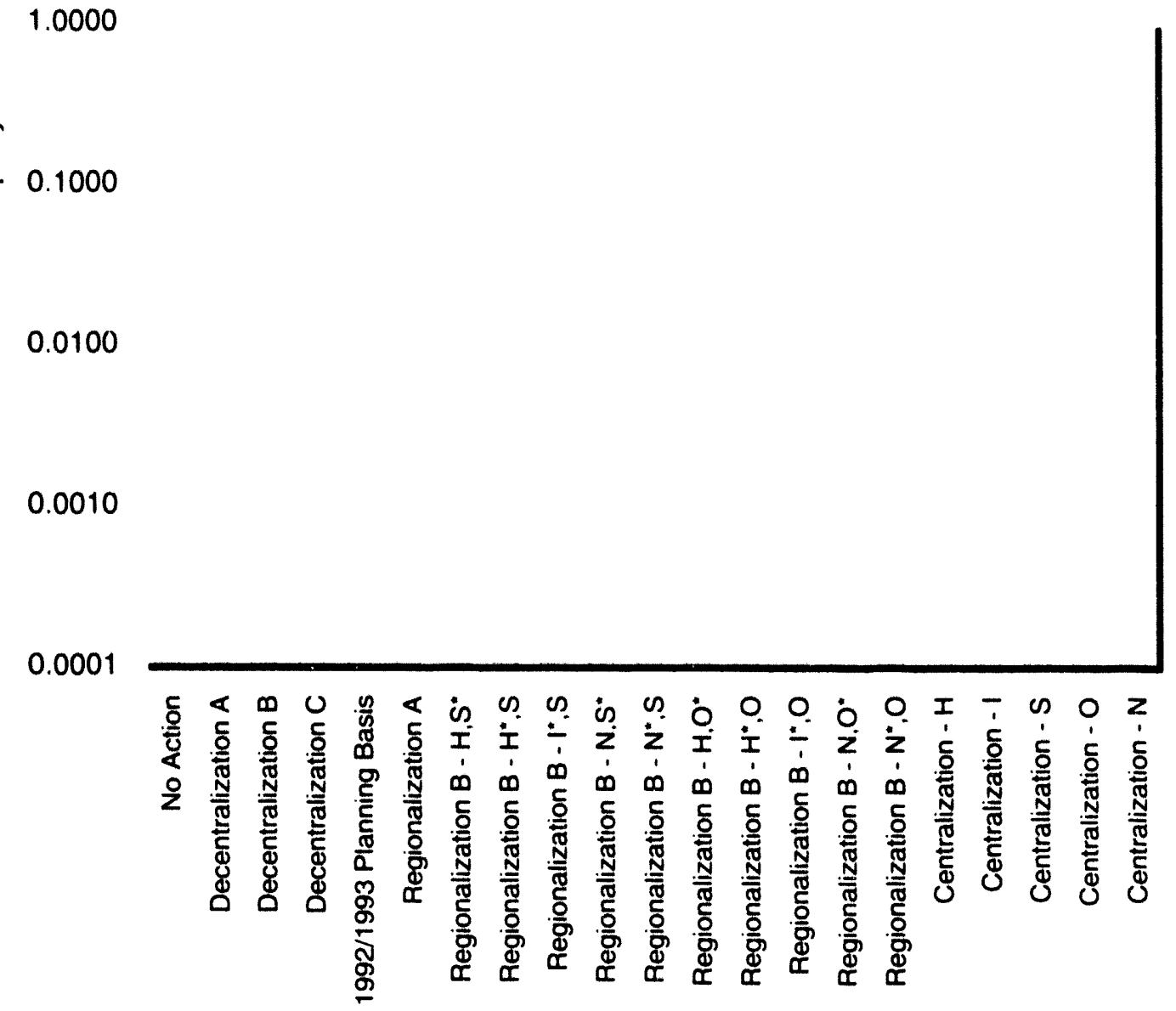

\section{Key:}

Decentralization A: No examination of Naval fuels

Decentralization B: Limited examination of Naval fuels at Puget Sound Naval Shipyard

Decentralization C: Full examination of Naval fuels at Idaho National Engineering Laboratory with SNF stored at Naval sites

Regionalization A: Regionalization by fuel type

Regionalization B: Regionalization by location

$$
\begin{array}{ll} 
& \text { H: Hanford Site } \\
\text { Site initials: } & \text { I: Idaho National Engineering Laboratory } \\
& \text { S: Savannah River Site } \\
& \text { O: Oak Ridge Reservation } \\
& \text { N: Nevada Test Site }
\end{array}
$$

* Location of Expended Core Facility

a. Facility risks are based on the product of the probability and consequences of the respective maximum foreseeable facility accident for each alternative and expressed in latent cancer fatalities per year.

Figure 12. Estimate of risk of latent cancer fatalities in general population from facility accidents for spent nuclear fuel management activities. 
The risk associated with radiation from transportation accidents pose's a lower risk than facility accidents (Figure 13). The risks associnted with traffic fatalities (nomradiological) are greater than the risks associated with cancer caused by radiation exposure, although both are very small (Figure 13). The evaluated transportation accident scenario with the largest consequences (spent nuclear fuel transportation accident in an urban area) would lead to .55 latent cancer fatalities; the probability of this occurrence is about 1 in 10 million. However, considering the probability of all accidents analyzed, the risk is nearly zero that is, much less than one over a 40-year period. The results provide estimates of maximum foreseeable consequences of very low probability accidents.

\section{Latent Cancer Fatallties Caused Per Rem for an Individual Member of the General Public}

\section{Dose:}

Radioactivity from ali sources combined, including natural and medical sources, produces about a 0.3 rem dose to the average individual per year.

\section{Probability:}

The probability of this happening is essentially one.

\section{Average life span:}

72 years is considered to be the average lifetime.

\section{Latent cancer fatalities caused per rem for an individual member of the general public:}

0.0005 cancers are estimated to be caused by exposure to 1 rem.

\section{Calculation:}

Dose rate $x$ life span $x$ cancers caused per rem $=$ $0.3 \mathrm{rem} /$ year $\times 72$ years $\times 0.0005$ cancers per rem $=$ 0.01 fatal cancers per individual lifetime.

Risk:

Probability $\times$ fatal latent cancers $=1 \times 0.01=0.01$ fatal cancer, which is about 1 chance in 100 of death from exposure to natural background radiation over a lifetime.
Thus, in summors, for rodicition induced latent cancer latalitien to the public aner to yearsot yent nucleas fuel management under all of the altermationesenalualed, the mont likes outoome is as follows:

- Cerolatent cancer fatalitien from normal facilits. operations and facility accidents

- Cerolatent cancer tatalitien from transportation accidents

- Zero latent cancer tatalities from most incident-free transportation under most alternatives; up to two latent cancer fatalities under the Centralization altermatice.

Up to one fatality could result over the 40-year period from nonradiological traffic accidents. By comparison about $40,0(0)$ people are killed annually in U.S. traffic accidents.

Although the anticipated potential for radiation exposures would be small, DOE would use the "as low' as reasonably achievable" principle for controlling exposures to workers and the public. For example, practices would be implemented to aroid or reduce production of potentially harmful substances and waste minimization would be practiced to reduce the toxicity and volume of secondary wastes to be managed. Furthermore, all sites would update their current worker training, emergency planning, emergency preparedness, and emergency response programs to address new spent nuclear fuel management activities.

\section{Spent Nuclear Fuel-Related Employment}

Under various alternative's, the total labor force involved in spent nuclear fuel management could decrease by 85 to 130 jobs or increase by more than 2,100 jobs, areraged over the period 


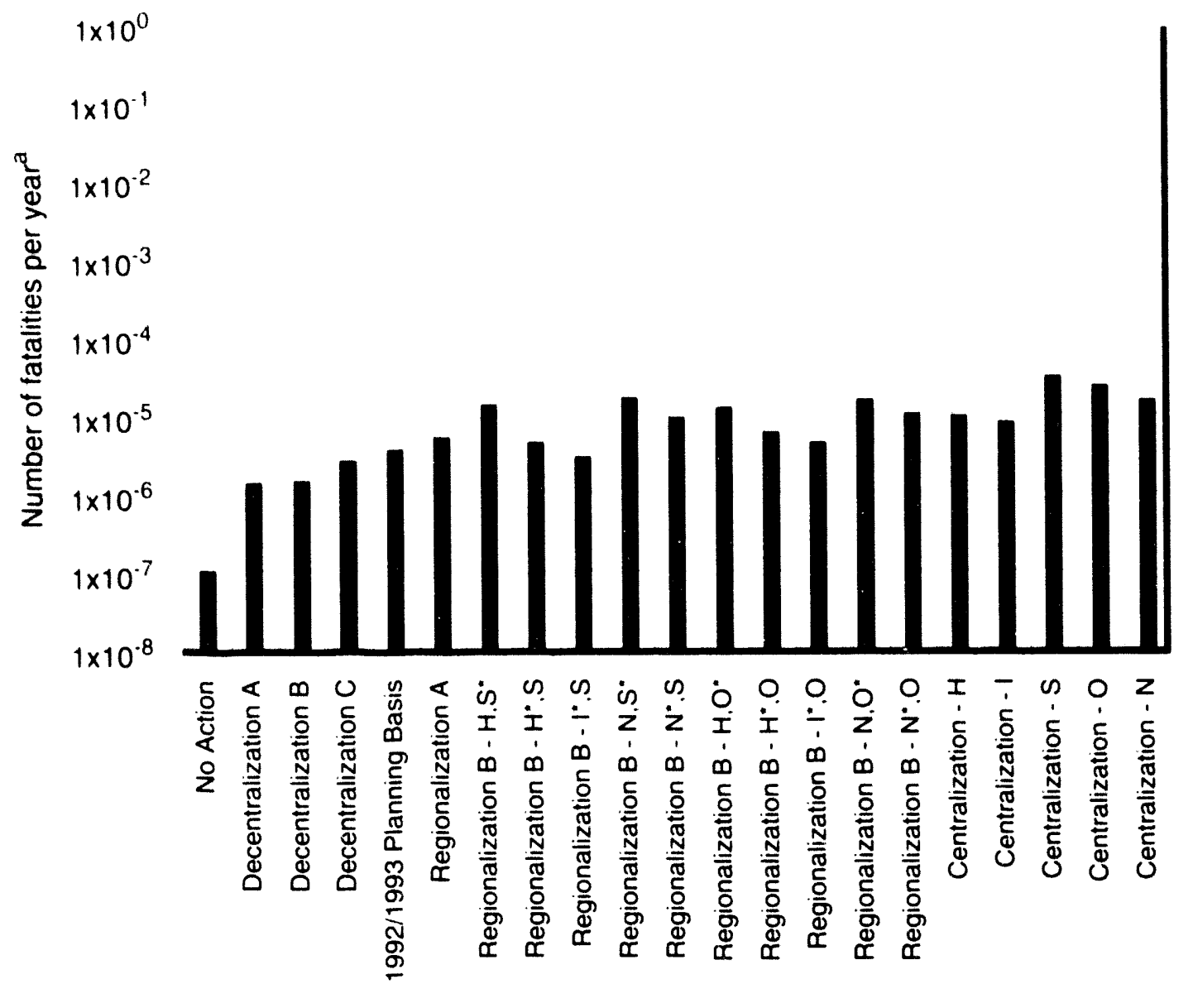

Key:

Decentralization A: No examination of Naval fuels

Decentralization B: Limited examination of Naval fuels at Puget Sound Naval Shipyard

Decentralization C: Full examination of Naval fuels at Idaho National Engineering Laboratory with SNF stored at Naval sites

Regionalization A: Regionalization by fuel type

Regionalization B: Regionalization by location

$$
\begin{array}{ll} 
& \text { H: Hanford Site } \\
\text { Site initials: } & \text { I: Idaho National Engineering Laboratory } \\
& \text { S: Savannah River Site } \\
& \text { O: Oak Ridge Reservation } \\
& \text { N: Nevada Test Site }
\end{array}
$$

Traffic fatality risk

Radiological risk

- Location of Expended Core Facility

a. Radiological risk is in terms of latent cancer fatalities per year from spent nuclear fuel shipments; traffic fatalitiy risk is in terms of estimated nonradiological traffic accident fatalities per year from spent nuclear fuel shipments

Figure 13. Estimate of average annual risk from transportation accidents for spent nuclear fuel management activities 


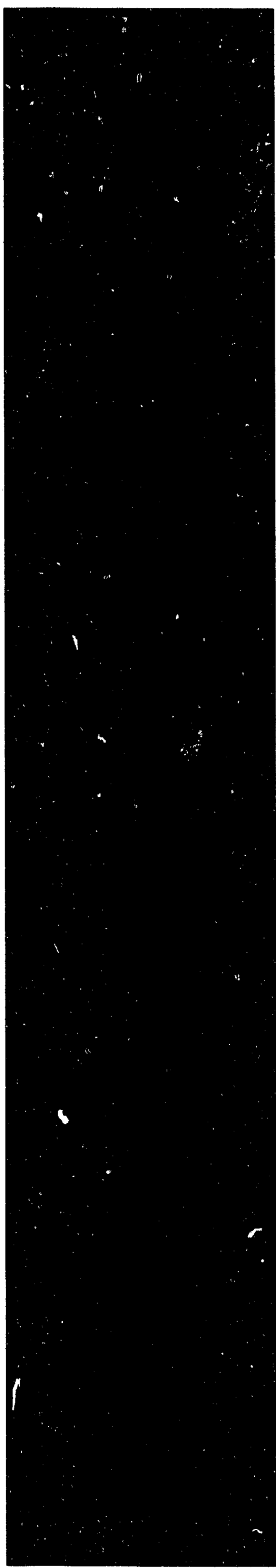

1995 to 2005, as compared to the 1995 baseline (Figure 14). The peak employment is difficult to estimate because it depends on implementation timing and funding profiles; however, the Regionalization alternative with the Nevada Test Site as the western site and Oak Ridge Reservation as the eastern site would result in the highest employment peak. The peak, estimated to be approximately 4,600 jobs in the year 2000, includes employment at sites preparing spent nuclear fuel cor shipment to the selected sites.

Under the No Action alternative, employment would not increase substantially for any site, and the closure of the Expended Core Facility at the Idaho National Engineering Laboratory would result in a net loss of just over 500 spent nuclear fuel management-related jobs.

Relocation of large amounts of spent nuclear fuel, such as under Regionalization Subalternative $B$ and the Centralization alternative, would eventually result in closure of spent nuclear fuel management facilities at major DOE sites and, thus, long-term job loss at the closed facilities.

However, some of the job losses at closed facilities would be accompanied by job gains at the sites receiving the shipped fuels.

For all three Decentralization options, the 1992/1993 Planning Basis alternative, and Regionalization Subalternative A, no more than an average additional 2,100 jobs would be required over the period 1995 to 2005 for implementation. Some of the more significant spent nuclear fuel employment requirements (particularly those involving the Hanford Site) would result from the development and operation of processing facilities needed to stabilize stored spent nuclear fuel. In addition, the relocation of the expended Core Facility to sites other than the Idaho National Engineering
Laboratory would result in an increase of about 500 jobs per year in the support of naval spent nuclear fuel examinations at those sites, and would result in a corresponding loss of approximately 500 jobs at the Idaho National Engineering Laboratory.

Thus, minor employment-related impacts are anticipated. To mitigate these impacts, DOE would coordinate its planning efforts with local communities and county planning agencies to address changes in community services, housing, infrastructure, utilities, and transportation. Such coordination with local planning agencies is intended to avoid placing undue burdens on local agency resources. DOE may provide support to local agencies if necessary.

\section{Generation of Radioactive Wastes}

When spent nuclear fuel is stored onsite, very little high-level, transuranic, or mixed waste is generated (see Figure 15). These small quantities of radioactive wastes would usually be generated during stabilization activities. As a result, under the No Action alternative fewer than 20 cubic meters ( 25 cubic yards) per year of transuranic wastes would be generated from spent nuclear fuel management nationwide because spent nuclear fuel would not be stabilized. Under all other alternatives, where stabilization activities would occur, between 20 and 50 cubic meters ( 25 and 65 cubic yards) of high-level waste and between 20 and 100 cubic meters ( 25 and 130 cubic yards) of transuranic waste would be generated each year. The lower generation rates would occur in the Decentralization alternative, where small amounts of spent nuclear fuel would be shipped among major DOE sites (and stabilization for shipment would not be necessary). 


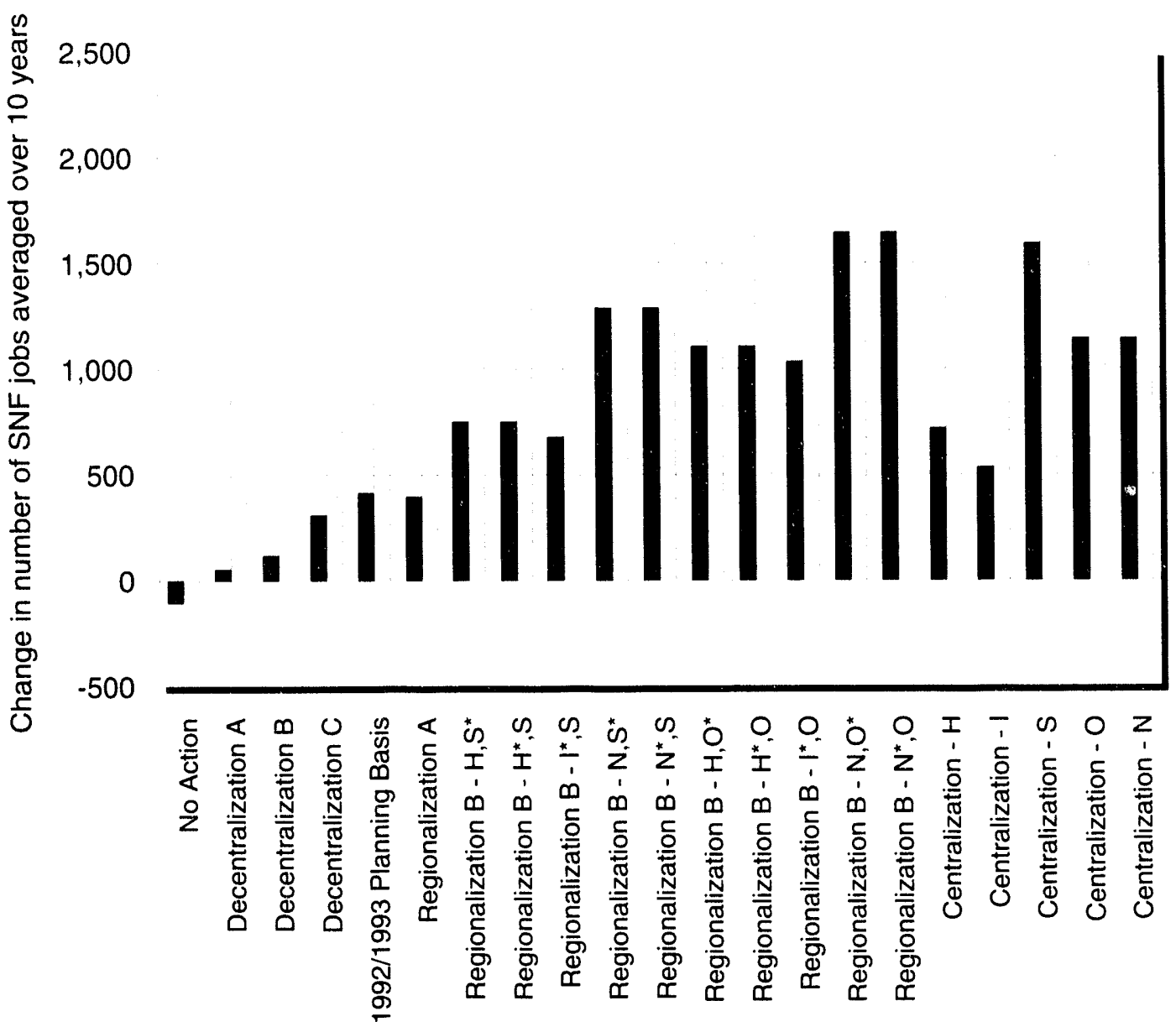

Key:

Decentralization A: No examination of Naval fuels

Decentralization B: Limited examination of Naval fuels at Puget Sound Naval Shipyard

Decentralization C: Full examination of Naval fuels at Idaho National Engineering Laboratory with SNF stored at Naval sites

Regionalization A: Regionalization by fuel type

Regionalization B: Regionalization by location

$\begin{array}{ll} & \text { H: Hanford Site } \\ \text { Site initials: } & \text { I: Idaho National Engineering Laboratory } \\ \text { S: Savannah River Site } & \text { Min }^{\mathrm{a}} \\ \text { O: Oak Ridge Reservation } & \\ \mathrm{N}: \text { Nevada Test Site } & \mathrm{Max}^{\mathrm{a}} \\ \text { ocation of Expended Core Facility } \\ \text { The maximum values occur with processing; the minimum values occur without processing. }\end{array}$

Figure 14. Change in the number of jobs averaged over the years 1995 to 2005 for spent nuclear fuel management activities. 


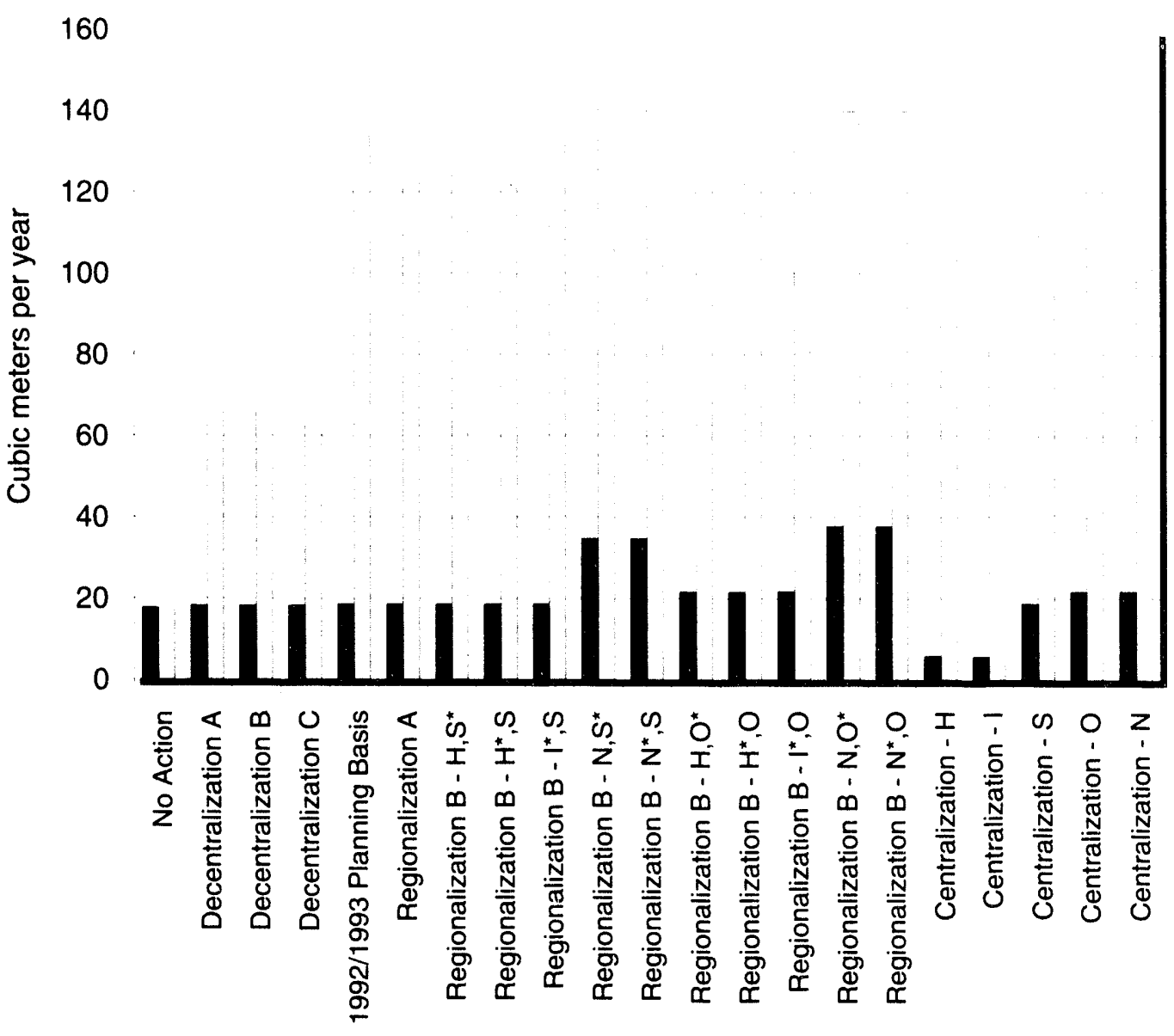

Key:

Decentralization A: No examination of Naval fuels

Decentralization B: Limited examination of Naval fuels at Puget Sound Naval Shipyard

Decentralization C: Full examination of Naval fuels at Idaho National Engineering Laboratory with SNF stored at Naval sites

Regionalization A: Regionalization by fuel type

Regionalization B: Regionalization by location
Site initials:
$H$ : Hanford Site
I: Idaho National Engineering Laboratory
S: Savannah River Site
O: Oak Ridge Reservation
$\operatorname{Min}^{\mathrm{a}}$
$\mathrm{N}$ : Nevada Test Site
$\operatorname{Max}^{\mathrm{a}}$

* Location of Expended Core Facility

a. The maximum values occur with processing; the minimum values occur without processing

Figure 15. Average volume of high-level, transuranic, and mixed waste generated per year over the years 1995 to 2005 for spent nuclear fuel management activities. 
For all other alternatives, greater amounts of spent nuclear fuel would be shipped among sites; therefore, more spent nuclear fuel would require stabilization before shipment and more waste would be generated.

Low-level waste also is generated as a result of spent nuclear fuel management. Figure 16 indicates an estimated range of annual volumes for each of the alternatives. The higher values are principally the result of processing for stabilization.

To control the volume of waste generated and reduce impacts on the environment, pollution prevention practices would be implemented. DOE is responding to Executive Order 12856, "Federal Compliance with Right to Know Laws and Pollution Prevention Requirements," and associated DOE orders and guidelines by reducing the use of toxic chemicals; improving emergency planning, response, and accident notification; and encouraging the development and use of clean technologies and the testing of innovative pollution prevention technologies. Pollution prevention programs have already been implemented at DOE sites. Program components include waste minimization, source reduction and recycling, and procurement practices that preferentially procure products made from recycled materials.

\section{Impact on DOE and Navy Missions}

The mission concerns of DOE and the Navy relate to storing spent nuclear fuel safely, meeting obligations, preparing spent nuclear fuel for ultimate disposition, and examining naval fuel. Under the 1992/1993 Planning Basis, Regionalization, and Centralization alternatives, the missions of DOE and the Navy would be met. Under the No Action and Decentralization alternatives, however, some parts of their missions would not be achieved.

DOE's mission is most severely impacted under the No Action alternative. In this alternative, only the minimal actions necessary would be undertaken to store spent nuclear fuel. This means that there would be no facility upgrades, no new facilities, and no new research and development activities. The consequences of pursuing this alternative could include any or all of the following:

- Progressive loss or reduction of safety margin as spent nuclear fuel and storage facilities deteriorate, posing greater threats to human health and the natural environment

- More frequent and possibly more costly repairs to equipment and facilities as the frequency of breakdowns increases

- Eventual loss of the use of storage facilities because equipment or facilities are beyond repair or because there is no flexibility in storage capacity to permit repair work

- No development of improved storage technologies and facilities, reducing DOE's ability to meet future needs and implement future decisions regarding ultimate disposition of spent nuclear fuel.

The Navy's mission would be hindered if the full examination of fuels at an Expended Core Facility were not possible. No or limited examination would occur under the No Action alternative and

Decentralization alternative (Options $A$ and $B$ ). The examinations are an important aspect of the Navy's ongoing advanced fuel research and

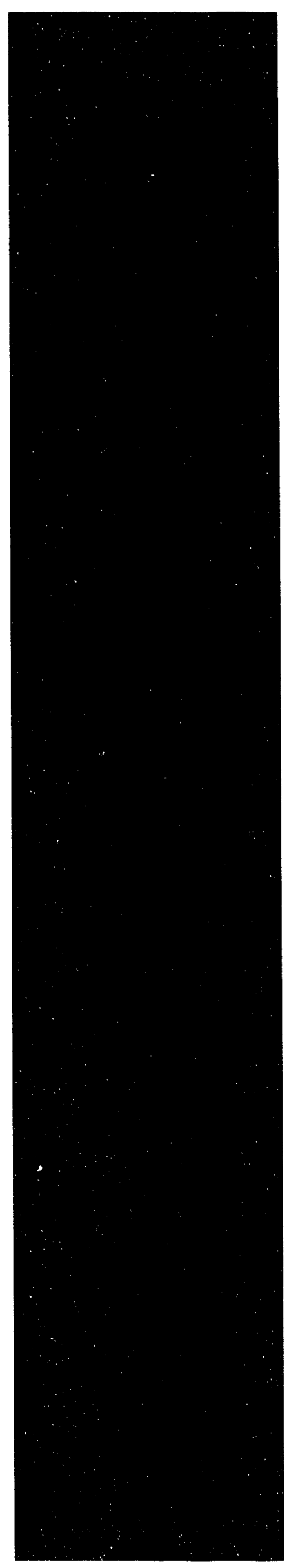




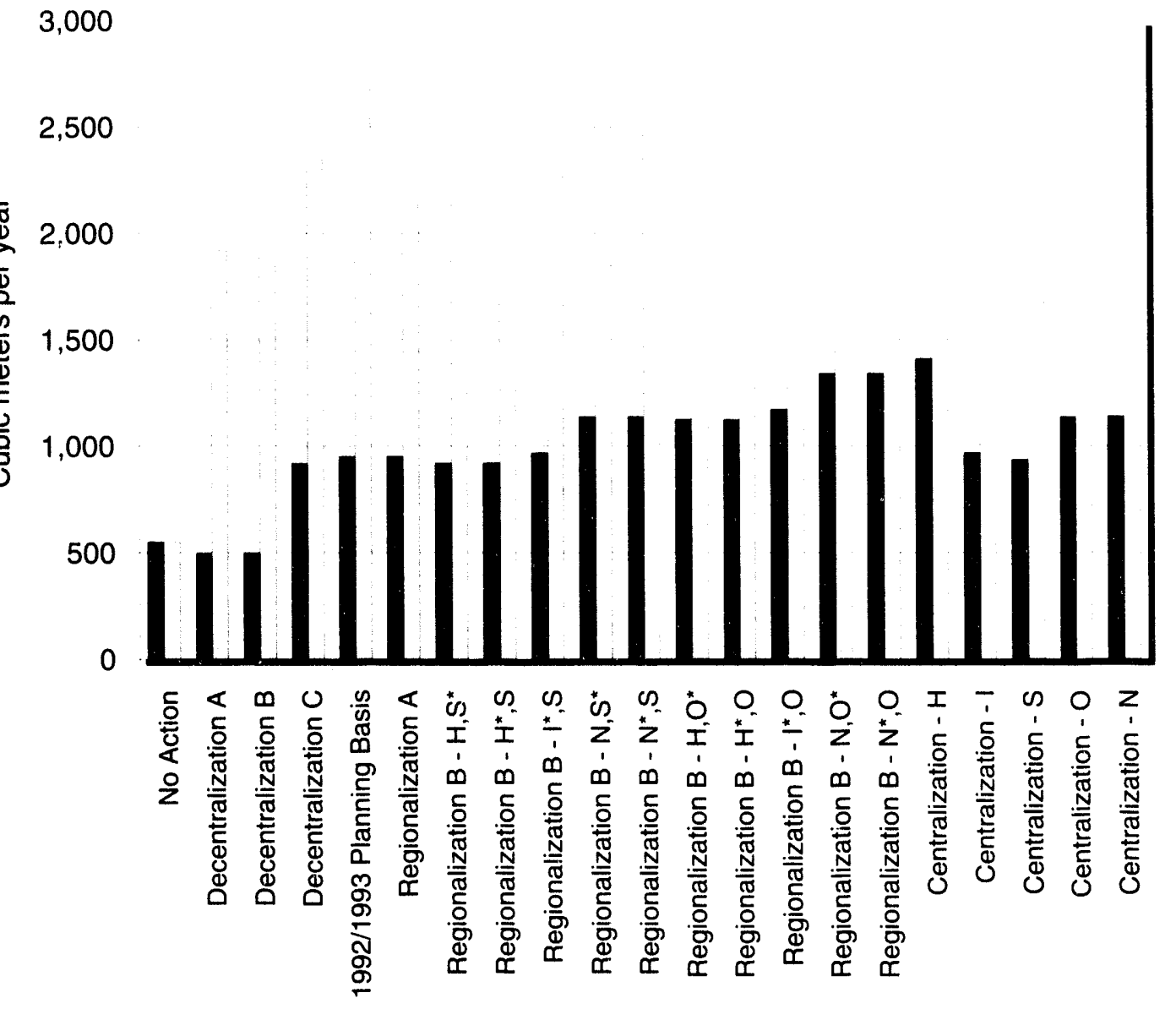

Key:

Decentralization A: No examination of Naval fuels

Decentralization B: Limited examination of Naval fuels at Puget Sound Naval Shipyard

Decentralization C: Full examination of Naval fuels at Idaho National Engineering Laboratory with SNF stored at Naval sites

Regionalization A: Regionalization by fuel type

Regionalization B: Regionalization by location

$\mathrm{H}$ : Hanford Site

Site initials: I: Idaho National Engineering Laboratory

S: Savannah River Site

O: Oak Ridge Reservation

$\mathrm{N}$ : Nevada Test Site

$\operatorname{Min}^{\mathrm{a}}$

$\operatorname{Max}{ }^{a}$

* Location of Expended Core Facility

a. The maximum values occur with processing; the minimum values occur without processing

Figure 16. Average volume of low-level wastes generated per year over the years 1995 to 2005 for spent nuclear fuel management activities. 
development program. The information derived from the examinations provides engineering data to support the design of new reactors, continued safety of existing reactors, and improvements in nuclear fuel performance and reactor operation by providing confirmation of their proper design and allowing maximum use of their fuel.

The No Action alternative would also impact ongoing nuclear research and training activities at universities that have little or no storage capacity for spent nuclear fuel. Such activities would cease once storage capacity is exhausted.

\section{Cost of Implementation}

To determine whether there are significant cost differences between EIS alternatives, DOE is developing a cost evaluation that it expects to complete and make available to the public before the Record of Decision is issued. This evaluation will allow near-term spent nuclear fuel decisions to be made with consideration of long-term (life cycle) cost implications. For each alternative, the cost evaluation will consider capital cost for upgrades to existing facilities and new facilities, operation and maintenance costs for existing and new facilities, decontamination and decommissioning costs for new facilities, and spent nuclear fuel transportation costs. While this evaluation will focus on spent nuclear fuel management costs, it will also address total system life cycle costs, including ultimate disposition alternatives such as repository disposal. The results of the evaluation will be considered by DOE in preparing the Record of Decision.

\section{Cumulative Impacts}

A cumulative impact results from the incremental impact associated with implementing an alternative plus the impacts of other past, present, and reasonably foreseeable future actions. "Other" actions include DOE projects at the potentially affected sites not related to spent nuclear fuel management, as well as projects of other Government agencies, private businesses, or individuals.

On a nationwide basis, the implementation of any of the spent nuclear fuel management alternatives would not significantly contribute to cumulative impacts. Although impacts to the natural environment (for example, water, air, ecology, and land use) were analyzed, the cumulative impacts are very small, especially if mitigation measures are taken.

In general, the contribution to cumulative impacts from activities required for spent nuclear fuel management would be very small at sites where fuel is stored, in comparison to other ongoing and reasonably expected nonfuel-related projects. Even for those alternatives (Regionalization or Centralization) where the use of nonrenewable resources would be relatively large, increases in the impacts at the selected site(s) would be accompanied by changes at nonselected sitesresulting in a very small net change.

On a site-specific basis, the implementation of any of the alternatives would not significantly contribute to cumulative impacts. Generally, the contribution to cumulative impacts from spent nuclear fuel management activities at a specific site is minor, relative to other DOE and non-DOE projects.

Radiological emissions from normal operations and from transportation of spent nuclear fuel would be well within regulatory requirements. The volumes of waste produced from fuel management activities would be a small addition to waste volumes generated by other ongoing and

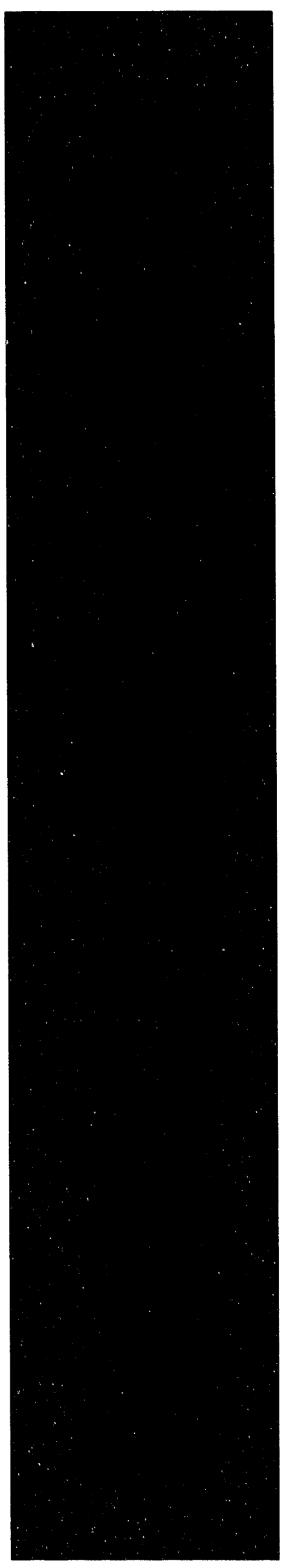


expected projects. For some

alternatives, increased employment

averaged over 10 years would be

relatively high (1992/1993 Planning

Basis, Regionalization Subalternative

$A$, and Decentralization). Even for

these alternatives, the net contribution

to cumulative impacts (such as

demand on housing or school

systems) would be low because of

anticipated overall declines in site

employment over the next few years. 
$O E$ is committed to operating its spent nuclear fuel management program in compliance with all applicable environmental laws, regulations, executive orders, DOE orders, and permits and compliance agreements with regulatory agencies. The DOE regulations that implement the National Environmental Policy Act require consultation with other agencies, when appropriate, to incorporate any relevant requirements as early as possible in the process. These consultation and coordination requirements will commence and be completed as site-specific spent nuclear fuel management projects and decisions are proposed. To the extent that this EIS supports existing sitespecific proposals, those consultations and coordination efforts are contained within Volume 2 of the EIS.

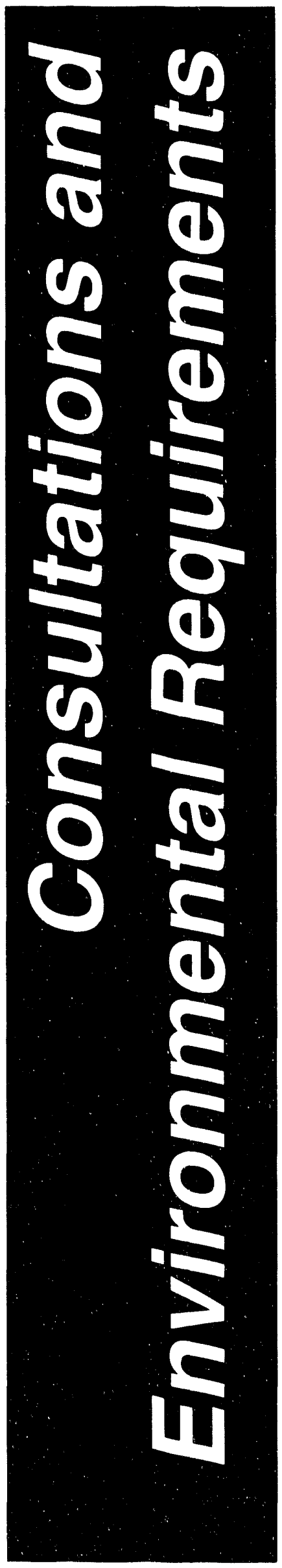




$$
\longrightarrow
$$

38 Sumımary 
()E is currently in the process of making two important sets of decisions. The first involves programmatic (DOE-wide) decisions regarding DOE's future spent nuclear fuel management (addressed in Volume 1 of the EIS). The second involves sitespecific decisions regarding the future direction of environmental restoration and waste management programs, which include spent nuclear fuel, at the Idaho National Engineering Laboratory (addressed in Volume 2 of this EIS).

DOE's programmatic decisions regarding spent nuclear fuel affect the Idaho National Engineering Laboratoryspecific decisions about spent nuclear fuel. Therefore, the spent nuclear fuel components of the Idaho National Engineering Laboratory-specific

\section{Volume 1-Programmatic Spent Nuclear Fuel Management Alternatives}

\section{No Action}

Take minimum actions required for safe and secure management of spent nuclear fuel at, or close to, the generation site or current storage location.

\section{Decentralization}

Store most spent nuclear fuel at or close to the generation site or current storage location, with limited shipments to DOE facilities.

\section{2/1993 Planning Basis}

Transport and store newly generated spent nuclear fuel at the Idaho National Engineering Laboratory or Savannah River Site. Consolidate some existing fuels at the Idaho National Engineering Laboratory.

\section{Regionalization}

Distribute existing and projected spent nuclear fuel among DOE sites, based primarily on fuel type (Subalternative A) or on geographical location (Subalternative B).

\section{Centralization}

Manage all existing and projected spent nuclear fuel inventories from DOE and the Navy at one site until ultimate disposition. alternative's have been constructed to bear a relationship to those of Volume 1. To the extent that this EIS supports existing site-specific proposals, those consultations and coordination efforts are contained within Volume 2 of the EIS.

\section{Volume 2-Idaho National Engineering Laboratory Spent Nuclear Fuel Management Alternatives}

\section{No Action}

- Phase out inspection of naval spent nuclear fuel. Close Expended Core Facility.

- Receive no non-naval spent nuclear fuel.

- Phase out Idaho Chemical

Processing Plant-603 storage pools.

\section{Ten-Year Plan}

- Examine and store naval spent nuclear fuel.

- Receive additional offsite spent nuclear fuel.

- Phase out Idaho Chemical

Processing Plant-603 storage pools.

- Expand storage capacity in existing

Idaho Chemical Processing Plant-666 pools.

-Phase in dry storage.

- Demonstrate actinide recycle.

\section{Minimum Treatment, Storage, and}

\section{Disposal}

- Phase out inspection of naval spent nuclear fuel. Close Expended Core Facility.

- Ship all spent nuclear fuel to DOE

Centralization site.

- Phase out spent nuclear fuel handling facilities.

- Demonstrate actinide recycle.

\section{Maximum Treatment, Storage, and}

Disposal

- Examine and store naval spent

nuclear fuel.

- Receive DOE-wide spent nuclear fuel. - Phase out Idaho Chemical

Processing Plant-603 storage pools. - Expand storage capacity in existing Idaho Chemical Processing Plant-666 pools.

-Phase in expanded dry storage.

- Demonstrate actinide recycle.

- Phase in spent nuclear fuel processing.

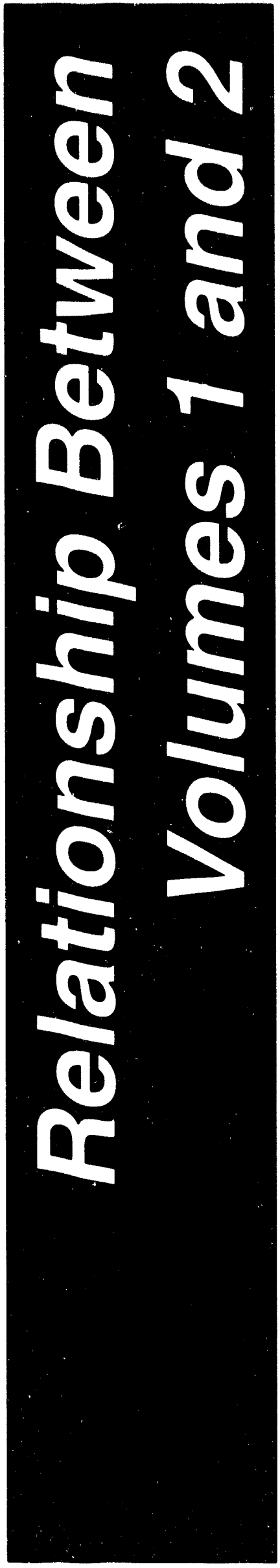


sites where there are known or suspected relensess of harmful substance's into the environment.

The Idaho National Engineering Laboratory's mission is to develop, demonstrate, and deploy advanced engineering technology and systems to improve national competitiveness and security, to make the production and use of energy more efficient, and to improve and to safely manage contaminated surplus nuclear facilities. Waste management program activities are designed to protect Idaho

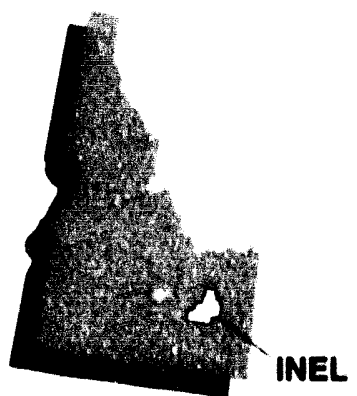
the quality of life and the environment.

The environmental restoration program includes activities to assess and clean up inactive Idaho National Engineering Laboratory operations, including waste

The Idaho National Engineering Laboratory is located in southeastern Idaho. effective, environmentally sound, regulatory compliant, and publicly acceptable manner.

\section{What Are Environmental Restoration and Waste Management?}

Environmental Restoration: The cleanup and restoration of sites and decontamination and decommissioning of facilities contaminated with radioactive and/ or hazardous substances during past operations.

Waste Management: The planning, coordination, and direction of those functions related to generation, minimization, handling, treatment, storage, transportation, and disposal of waste, as well as associated surveillance and maintenance activities.

Spent nuclear fuel management at the ldaho National Engineering Laboratory includes (a) accepting and examining shipments from generators or from other storage sites, (b) setting standards and approving methods for storing spent nuclear fuel and preparing (stabilizing) it for such storage, (c) constructing and operating facilities for stabilization, plus interim storage, (d) consolidating storage and retiring outdated storage facilities, and $(\theta)$ developing criteria and technologies for ultimate disposition of spent nuclear fuel (or its components). DOE is developing spent nuclear fuel management plans for a 40-year timeframe that are anticipated to be sufficient to cover the period during which ultimate disposition will be established and implemented for DOE's spent nuclear fuel.

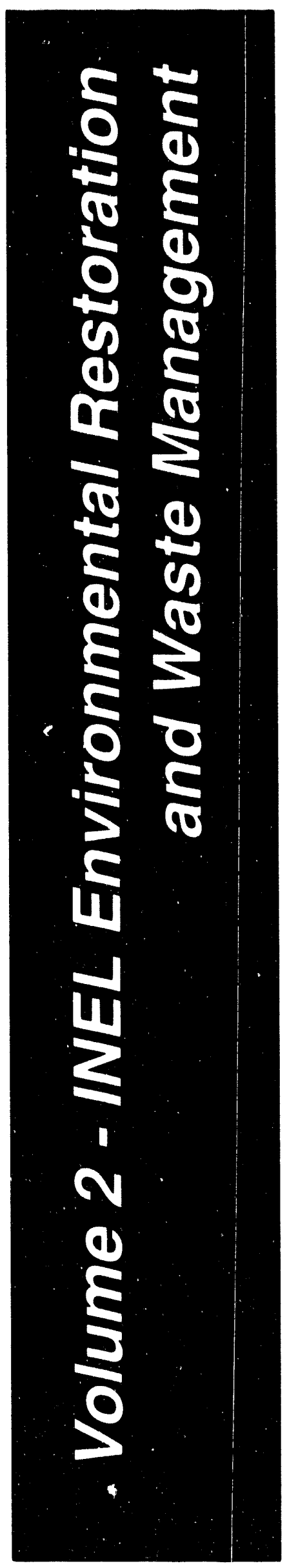




\section{aste Management}

Waste management includes minimization, characterization, treatment, storage, and disposal of waste generated from ongoing Idaho National Engineering Laboratory activities and from the Environmental Restoration Program. The Waste Management Program ensures that current and future waste management practices minimize any additional adverse environmental impacts. This is accomplished through such

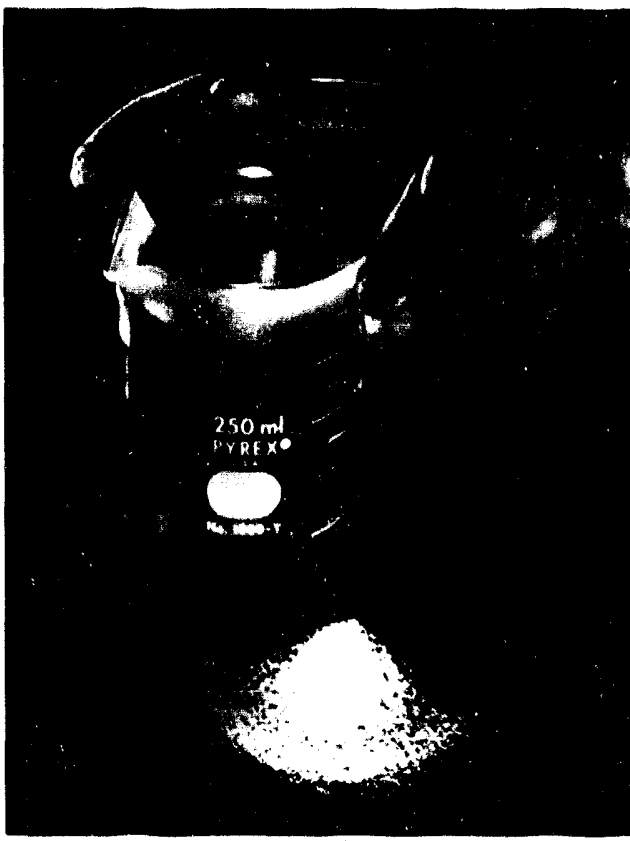

Calcination is one form of waste management. practices as waste reduction and recycling, and treatment technologies such as volume reduction and waste separation techniques. Every operating facility within the nine major facility areas at the Idaho National Engineering Laboratory produces waste that must be managed. Table 2 summarizes the primary functions of each facility area.

\section{Environmental Restoration}

The Idaho National Engineering Laboratory Environmental Restoration Program addresses contamination resulting from the past 50 years of operations. The goals of the Environmental Restoration Program are to clean up past environmental contamination and to decontaminate and decommission facilities that are no longer needed (surplus). The cleanup program is conducted under a Federal Facility Agreement and Consent Order, entered into by the DOE, the U.S. Environmental Protection Agency, and the State of ldaho, in accordance with the comprehensive Environmental Response, Compensation, and Liability Act of 1980), as amended.

Since 1986, orer $f()()$ suspected release sites have been identified for investigation. Potential release sites were grouped together for efficiency into 10 areas called Waste Area Groups. Nine of the groups are roughly equivalent to the major facility areas at the Idaho National Engineering Laboratory.

Waste Area Group 10 includes a sitewide area associated with the Snake River Plain Aquifer and surface and subsurface areas that are not addressed by the other nine Waste Area Groups. Of the more than 400 sites, over 100 have been proposed or designated as requiring no further action.

Sources of contamination include spills, abandoned tanks, septic systems, percolation ponds, landfills, and injection wells. Contaminated sites range in size from large facilities such as the pits and trenches at the Radioactive Waste Management Complex to small areas where minor spills have occurred.

Environmental restoration also involves safely managing contaminated surplus nuclear facilities until they are decontaminated for reuse or are decommissioned

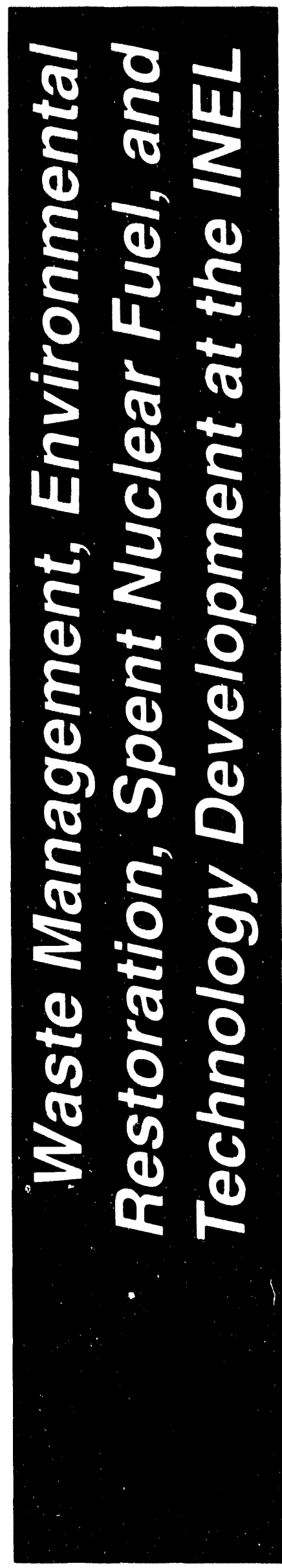




\section{Spent Nuclear Fuel}

Since the 1950s, spent nuclear fuel removed from nuclear-powered naval vessels and naval reactor prototypes has been shipped to the Naval
Reactors Facility located at the Idaho National Engineering Laboratory. Spent nuclear fuel has also been received from university, commercial, industrial, DOE, and other U.S.

Government and foreign reactors.

Table 2. Functions of major facility areas at the Idaho National Engineering Laboratory.

\begin{tabular}{ll} 
Major facility area & \multicolumn{1}{c}{ Function performed } \\
\hline Test Area North & $\begin{array}{l}\text { Handle and evaluate irradiated materials; support } \\
\text { energy and defense programs; support testing of } \\
\text { casks for interim storage of spent nuclear fuel; study } \\
\text { spent nuclear fuel transportation; store spent nuclear } \\
\text { fuel. }\end{array}$ \\
Test Reactor Area & $\begin{array}{l}\text { Study effects of radiation on materials, fuels, and } \\
\text { equipment; manage seven reactors (two operating, two in } \\
\text { standby, three deactivated); perform chemistry and } \\
\text { physics experiments. }\end{array}$
\end{tabular}

Idaho Chemical Processing Plant

Central Facilities Area
Receive and store spent nuclear fuel; prepare high-level liquid and solid waste for disposal; develop and apply technologies for eventual disposal of spent nuclear fuel, disposal of sodiumbearing and high-level waste, minimization of waste generation, and management of radioactive and hazardous wastes.

Provide technical and support services for the Idaho National Engineering Laboratory, including environmental monitoring and calibration laboratories, communication systems, security, fire protection, medical services, warehouse, cafeteria, vehicle and equipment pools, and bus operations; operate Hazardous Waste Storage Facility and Idaho National Engineering Laboratory Landfill Complex.

Power Burst Facility/ Support waste management-related research Auxiliary Reactor Area

\section{Experimental Breeder Reactor-1/ Boiling Water Reaitior Experiment}

Radioactive Waste Management Complex

Naval Reactors Facility (Expended Core Facility)

Argonne National Laboratory-West (volume reduction and waste immobilization); develop decontamination, waste storage and treatment technologies.

National Historic Landmark

Store and dispose of wastes; support research and development for interim storage of transuranic waste, low-level waste disposal, buried waste remediation technologies, and environmental cleanup technologies.

Receive and conduct examination of spent nuclear fuel to support fuel development and performance analyses.

Develop and test breeder reactor technology; store transuranic waste; support research and development of spent nuclear fuel treatment technologies. 
Spent nuclear fuel continues to be generated at the Idaho National Engineering Laboratory by reactor operations. Naval reactor fuel, currently examined at the Naval Reactors Facility, is transferred to the
Idaho Chemical Processing Plant for storage at a rate of about 1 metric ton per year. Spent nuclear fuel is stored at a number of site areas in various dry and wet storage facilities awaiting ultimate disposition.
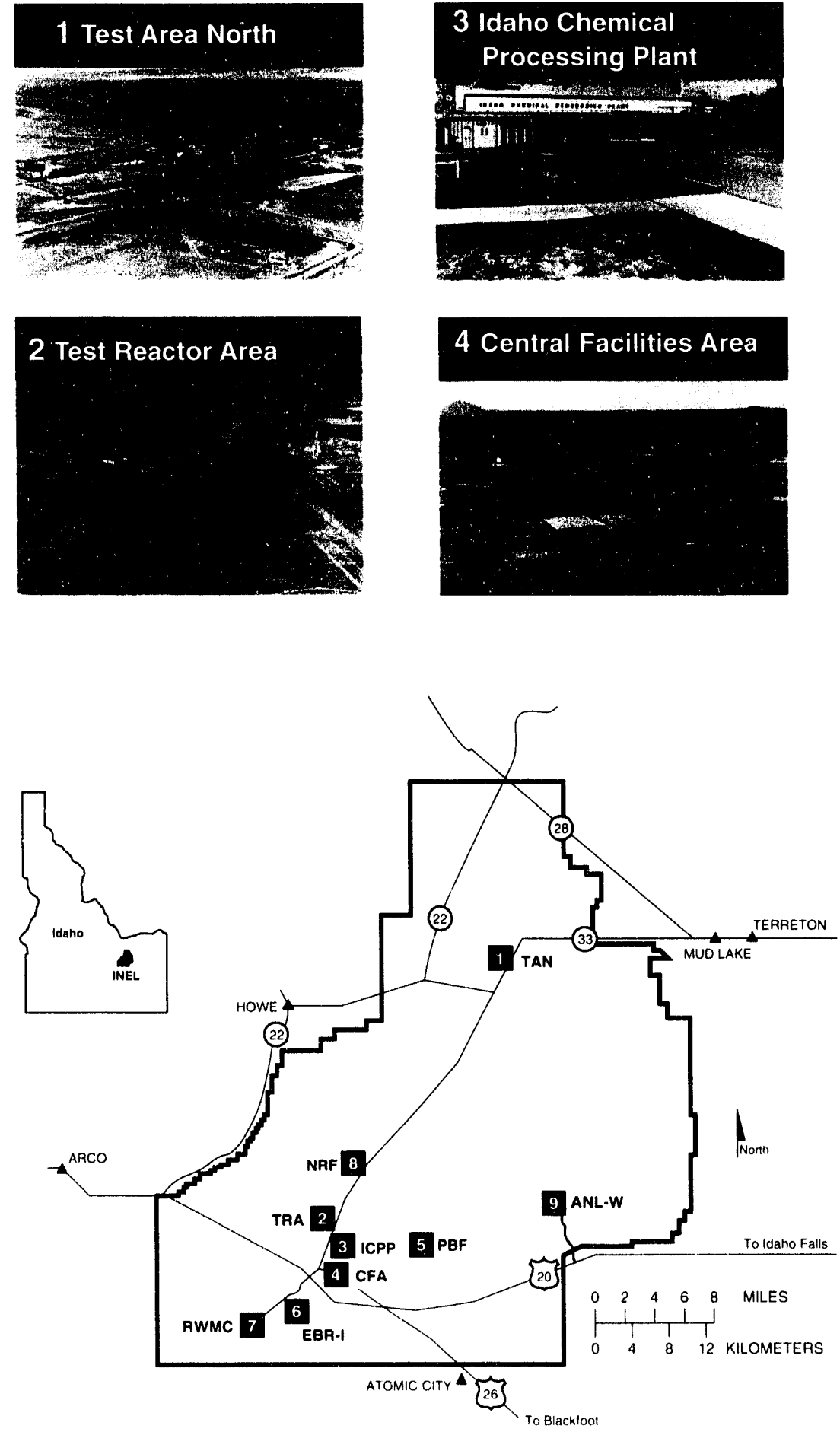

Major facility areas located at the Idaho National Engineering Laboratory site.

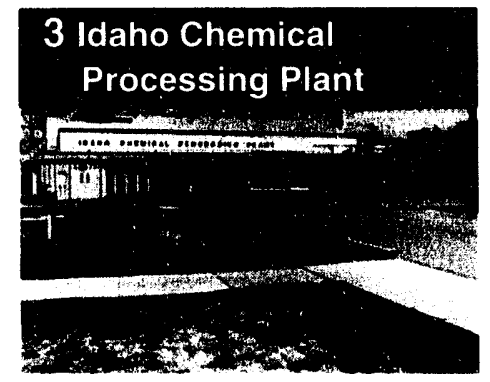

\section{Central Facilities Area}
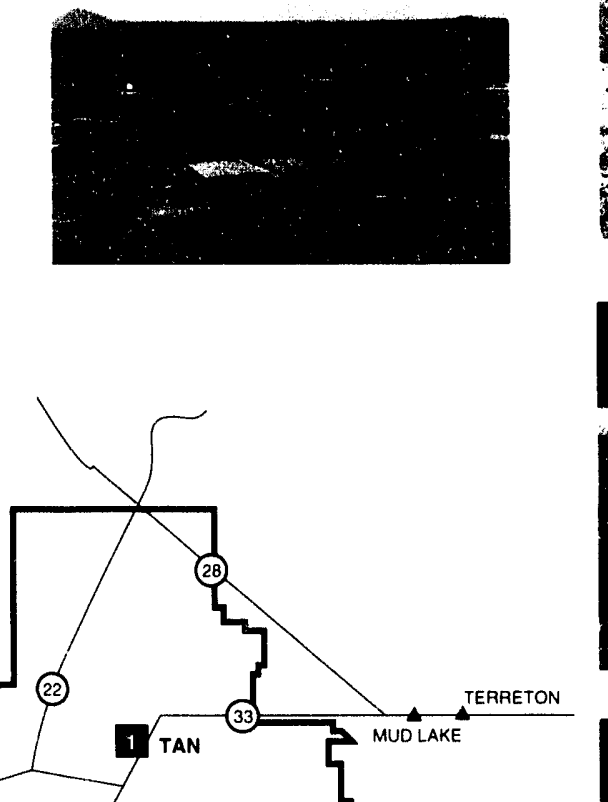

5 Power Burst Facility

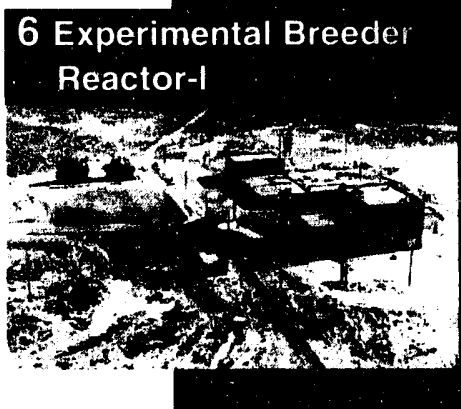

7 Radioactive Waste Management Complex

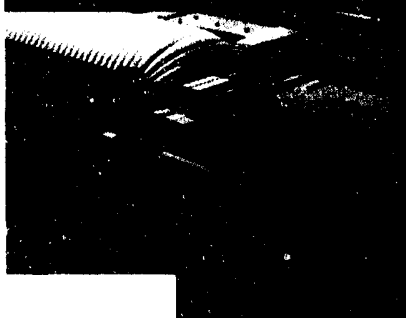

8 Naval Reactors Facility

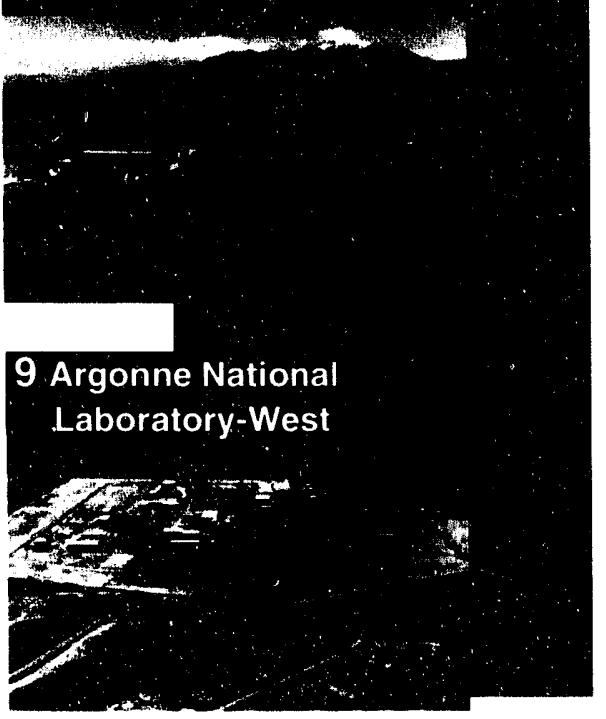




\section{Technology Development}

Technology development supports the Environmental Restoration, Waste Management, and Spent Nuclear Fuel Programs by designing and testing potential technical solutions to specific problems. Broad program areas include research, development, demonstration, testing, and evaluation; technology integration; development of safe and efficient packaging systems; emergency response management; education; and laboratory analysis. Types of current technology development activities include minimizing waste; testing cleanup technologies; evaluating and testing methods to treat calcined, sodium-bearing, and high-level wastes; and designing sensors and other environmental monitoring equipment and systems. An example of research activity includes investigating treatment technologies to prepare fuel for ultimate disposition.

\section{Waste at the Idaho National Engineering Laboratory}

Alpha Low-Level Waste: Waste that was previously classified as transuranic waste but has a transuranic concentration lower than the currently established limit for transuranic waste. Alpha low-level waste requires additional controls and special handling (relative to low-level waste). This waste stream cannot be accepted for onsite disposal under the current waste acceptance criteria; therefore, it is specialcase waste.

Greater-Than-Class-C Waste: Low-level radioactive waste that is generated by the commercial sector and that exceeds U.S. Nuclear Regulatory Commission concentration limits for Class $\mathrm{C}$ low-level waste as specified in Title 10 Code of Federal Regulations Part 61. DOE is responsible for the disposal of Greater-Than-Class-C wastes from DOE non-defense programs.

Hazardous Waste: Under the Resource Conservation and Recovery Act, a solid waste, or combination of solid wastes, which because of its quantity, concentration, or physical, chemical, or infectious characteristics may (a) cause, or significantly contribute to, an increase in mortality or an increase in serious irreversible, or incapacitating reversible, illness; or (b) pose a substantial present or potential hazard to human health or the environment when improperly treated, stored, transported, disposed of, or otherwise managed. Source, special nuclear material, and byproduct material, as defined by the Atomic Energy Act, are specifically excluded from the definition of solid waste.

High-Level Waste: The highly radioactive waste material that results from the reprocessing of spent nuclear fuel, including liquid waste produced directly from reprocessing and any solid waste derived from the liquid that contains a combination of transuranic and fission product nuclides in quantities that require permanent isolation. High-level waste may include other highly radioactive material that the U.S. Nuclear Regulatory Commission, consistent with existing law, determines by rule requires permanent isoiation.

Low-Level Waste: Waste that contains radioactivity and is not classified as high-level waste, transuranic waste, or spent nuclear fuel. Test specimens of fissionable material irradiated for research and development only, and not for the production of power or plutonium, may be classified as low-level waste, provided the concentration of transuranic elements is less than 100 nanocuries per gram.

Mixed Waste: Waste that contains both hazardous waste under the Resource Conservation and Recovery Act and source, special nuclear, or byproduct material subject to the Atomic Energy Act.

Transuranic Waste: Waste containing more than 100 nanocuries of alpha-emitting transuranic isotopes, per gram of waste, with half-lives greater than 20 years, except for (a) high-level radioactive waste, (b) waste that the DOE has determined, with the concurrence of the Administrator of the U.S. Environmental Protection Agency, does not need the degree of isolation required by Title 40 Code of Federal Regulations Part 191, and (c) waste that the U.S. Nuclear Regulatory Commission has approved for disposal on a case-by-case basis in accordance with Title 10 Code of Federal Regulations Part 61. 
$\mathrm{OE}$ is responsible by law for spent nuclear fuel management, waste management, and environmental restoration at the Idaho National Engineering Laboratory in southeastern Idaho. Under the Atomic Energy Act of $1954, \mathrm{DOE}$ is also responsible for managing certain spent nuclear fuels. DOE also is responsible for managing wastes and controlling hazardous substances in a manner that protects human health and the environment under the Comprehensive Environmental Response, Compensation, and Liability Act of 1980, as amended; the Resource Conservation and Recovery Act of 1976; the Federal Facility Compliance Act of 1992; and other laws. DOE is

committed to comply with these and all other applicable Federal and State laws and regulations, DOE orders, and interagency agreements governing spent nuclear fuel, environmental restoration, and waste management.

Over the past 50 years, DOE activities have resulted in the accumulation of spent nuclear fuel; waste requiring treatment, storage, and disposal; and sites requiring cleanup. To better fulfill its responsibilities, DOE needs to develop and implement a program for spent nuclear fuel management, environmental restoration, and waste management at the Idaho National Engineering Laboratory. To establish an effective program for the foreseeable future (focused on the next 10 years), DOE needs to make site-specific decisions that would accomplish three major goals: (a) support research and development missions at the Idaho National Engineering Laboratory; (b) comply with legal requirements governing spent nuclear fuel management, environmental restoration, and waste management, and (c) manage spent nuclear fuel, treat, store, and dispose of waste, and conduct environmental restoration activities at the Idaho National Engineering Laboratory in an environmentally sound manner.

To achieve these goals, DOE needs to develop appropriate facilities and technologies to manage waste and spent nuclear fuel expected during the next 10 years; to more fully integrate all environmental restoration and waste management activities at the Idaho National Engineering Laboratory to achieve cost and operational efficiencies; and to minimize environmental impacts from environmental restoration and waste management activities.

\section{What Are the Decisions to Be Made Based on This EIS?}

Spent Nuclear Fuel: What is the appropriate strategy of the Idaho National Engineering Laboratory to implement DOE's national spent nuclear fuel decisions regarding transportation, receipt, processing, and storage of spent nuclear fuel? What is the appropriate storage capacity for spent nuclear fuel?

Environmental Restoration and Waste Management: What is the appropriate strategy of the Idaho National Engineering Laboratory to implement DOE's national environmental restoration and waste management decisions?

What is the appropriate cleanup strategy under the Comprehensive Environmental Response, Compensation, and Liability Act of 1980, as amended, and the Federal Facility Agreement and Consent Order of 1991?

What are the necessary capabilities, facilities, research and development, and technologies for treating, storing, and disposing of each waste type?

What treatment technologies should be used for sodium-bearing and high-level wastes and other radioactive and mixed waste?

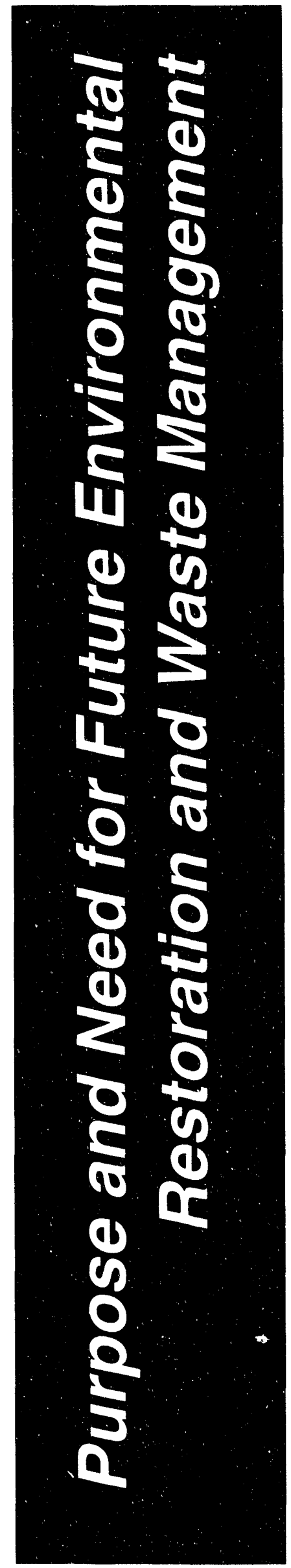


OE has chosen four alternatives that represent a range of possible actions. Each alternative includes components for cleanup, decontamination and decommissioning, waste management, and spent nuclear fuel management. Infrastructure, technology development, and transportation were also considered. The alternatives, which reflect the public scoping process, take the following factors into account:

- The sources of waste and spent nuclear fuel that (a) exist at the Idaho National Engineering Laboratory by June 1995 ,

(b) would be generated between 1995 and 2005, and (c) might be transported to the Idaho National Engineering Laboratory from other sites.

- The prac : cal waste and spent nuclear fuel management options, including characterization, storage, and disposal, or stabilization (spent nuclear fuel) and treatment (waste).

- The locations at which the waste and spent nuclear fuel management could reasonably be undertaken, either on or off the Idaho National Engineering Laboratory site.

Given this, DOE determined the projects and actions needed to manage the waste and spent nuclear fuel associated with each alternative. This EIS provides the analysis required under the National Environmental Policy Act for certain projects that DOE proposes as part of the spent nuclear fuel, environmental restoration, and waste management program at the Idaho National Engineering Laboratory.

The Idaho National Engineering Laboratory-specific management actions that DOE selects are likely to be a combination of specific elements from within the several alternatives analyzed. As yet, DOE has not identified a preferred alternative. A preferred alternative will be identified in the final EIS, following receipt and consideration of public comments on the draft EIS.

However, the Navy, as a cooperating agency, has stated a preferred alternative to continue refueling and

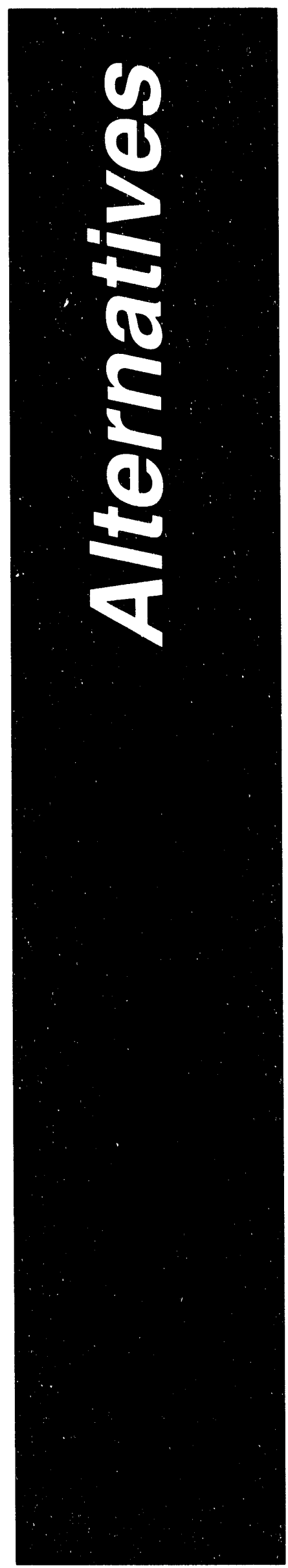


defueling nuclear-powered vessels and prototypes, and to transport spent fuel to the ldaho National Engineering Laboratory for full examination and interim storage, using the same practices as in the past. restoration and waste management program at the Idaho National Engineering Laboratory would also continue. There would be no shipments of spent nuclear fuel to the Idaho National Engineering Laboratory, with the exception of shipments of naval fuel during an

\section{Projects Related to Alternatives}

In addition to current operations and activities at the Idaho National Engineering Laboratory, there are 49 projects that form the basis for analysis of reasonably foreseeable future impacts in Volume 2 . These 49 projects fall under the various Alternatives $A, B, C$, and $D$. The 49 projects include twelve projects whose National Environmental Policy Act documentation is already completed or is expected to be completed before the Record of Decision. An objective of Volume 2 and its appendices is to provide sufficient analysis for another twelve projects (listed below) to allow timely deployment if needed for the project. DOE would evaluate the remaining 25 projects on a case-by-case basis to determine if any additional NEPA or further evaluation is needed before implementing the project.
- Expended Core Facility Dry Cell Project

- Increased Rack Capacity for Building 666 at the Idaho Chemical Processing Plant

- Dry Fuel Storage Facility; Fuel Receiving, Canning/Characterization, and Shipping

- Fort St. Vrain Spent Nuclear Fuel Shipment and Storage

- Tank Farm Heel Removal Project

- Waste Immobilization Facility

- High-Level Tank Farm New Tanks

- Shipping/Transfer Station

- Waste Experimental Reduction Facility Incineration

- Nonincinerable Mixed Waste Treatment

- Industrial/Commercial Landfill Expansion

- Gravel Pit Expansions

$\frac{\text { Alternative }^{\mathrm{a}}}{\mathrm{B}, \mathrm{D}}$
B, D
B, C, D
B, D
B, C, D
B, C, D
C, D
C
B, D
B, D
B, C, D
B, D

a. Alternative $A=$ No Action, Alternative $B=$ Ten-Year Plan, Alternative $C=$ Minimum Treatment, Storage, and Disposal, Alternative $D=$ Maximum Treatment, Storage, and Disposal.

b. These projects would be expanded for Alternative D (Maximum Treatment, Storage, and Disposal).

c. Sodium-bearing and calcine waste treatment technology selection would be implemented through this facility. approximately threeyear transition period. Existing inventories of spent nuclear fuel would remain in storage onsite. Activities and projects would include those that may be initiated after June 1995 but that have been evaluated under the National Environmental Policy Act by that date.

New activities would be limited to those required to maintain safe operation. Implementation of Alternative A (No Action) would not fully meet all negotiated agreements and commitments under the Federal Facility Agreement and Consent Order and obligations to receive spent nuclear fuel from universities and Fort St. Vrain.

\section{Alternative A (No} Action) represents a baseline against which the potential environmental impacts of the other alternatives are compared.

Under Alternative A (No Action), existing environmental restoration and waste management operations and projects would continue. Research and development and infrastructure facilities and projects that support the environmental

\section{Alternative B (Ten-Year Plan)}

Under Alternative B (Ten-Year Plan), existing environmental restoration and waste management facilities and 
projects would continue to be managed. In addition to current facilities and projects, those proposed for 1995 through 2005 would be implemented to meet the current Idaho National Engineering Laboratory mission and to comply with negotiated agreements and commitments.

Under this alternative, spent nuclear fuel, environmental restoration, and waste management activities would be continued and enhanced to meet expanded spent nuclear fuel and waste handling needs. These enhanced activities would be needed to comply with regulations and agreements and would result from acceptance of additional offsite materials and waste. Waste generation from onsite sources would increase because of increased decontamination and decommissioning and environmental restoration activities. Spent nuclear fuel and selected waste would be received from other DOE sites. Onsite management would emphasize greater treatment and disposal capabilities, compared to Alternative A (No Action). Additional cleanup and decommissioning and decontamination projects would be conducted under this alternative.

\section{Alternative $\mathbf{C}$ (Minimum Treatment, Storage, and Disposal)}

Under Alternative C (Minimum Treatment, Storage, and Disposal), ongoing Idaho National Engineering Laboratory spent nuclear fuel and waste management activities, along

\section{Alternative A (No Action)}

Spent Nuclear Fuel: Phase out examination of naval spent nuclear fuel after an approximate three-year transition period; no other fuels would be received; hase out storage pools at Building 603 of the Idaho Chemical Processing Plant.

Environmental Restoration: Conduct no activities other than already approved projects; decontaminate and decommission Auxiliary Reactor Area (ARA)-II and Boiling Water Reactor Experiment (BORAX)-V; clean up groundwater and vadose zone contamination; retrieve and treat Pit 9 waste.

High-Level Waste: Convert liquid to solid calcine.

Transuranic Waste: Retrieve/move transuranic and alpha low-level waste to new compliant storage; ship transuranic waste offsite for disposal; accept offsite waste for storage on case-by-case basis.

Low-Level Waste: Treat onsite and offsite; dispose of onsite in existing facility.

Mixed Low-Level Waste: Treat onsite (nonincineration).

Greater-than-Class-C Waste: Continue management programs.

Hazardous Waste: Ship offsite for treatment, storage, and disposal.

with materials and waste, would be transferred to other locations to the extent possible. Possible locations include DOE facilities, other Government sites, or private sector locations to the extent possible. Minimal treatment, storage, and disposal activities would be located at the Idaho National Engineering Laboratory.

Waste and spent nuclear fuel would not be received from offsite sources for management by the Idaho National Engineering Laboratory. Whenever feasible, wastes generated from onsite environmental restoration activities would be minimized by emphasizing institutional controls over treatment options. Only current cleanup and decommissioning and decontamination projects would be conducted under this alternative. Existing onsite spent nuclear fuel and waste management capability

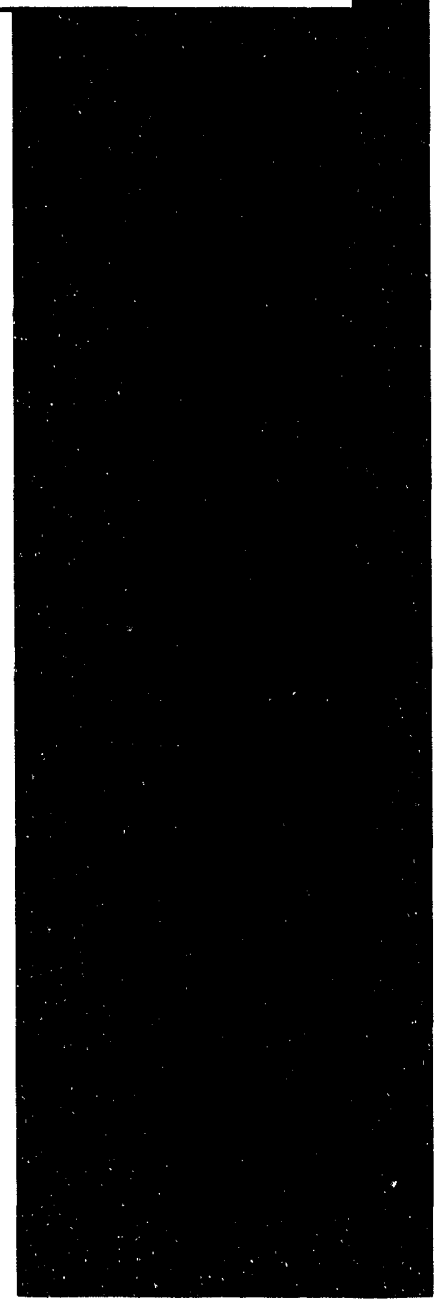




\section{Alternative B (Ten-Year Plan)}

Spent Nuclear Fuel: Receive additional offsite spent nuclear fuel; examine and store naval spent nuclear fuel; complete Expended Core Facility Dry Cell Project and expand storage capacity in pools at Building 666 of the Chemical Processing Plant; phase out pools at Building 603 of the Idaho Chemical Processing Plant; phase in new dry storage; demonstrate actinide recycle at Argonne National Laboratory-West.

Environmental Restoration: Conduct all planned projects in all Waste Area Groups; decontaminate and decommission Auxiliary Reactor Area (ARA)-II, Boiling Water Reactor Experiment (BORAX)-V, Engineering Test Reactor, Materials Test Reactor, Fuel Processing Complex, Fuel Receipt/Storage Facility, Headend Processing Plant, Waste Calcine Facility, and Central Liquid Waste Processing Facility; clean up groundwater contamination and vadose zone; clean up buried wastes and Idaho Chemical Processing Plant; retrieve and treat Pit 9 wastes.

High-Level Waste: Select the technology to convert liquid to calcine; construct a facility to immobilize both liquid and solid calcine for operation in 2008.

Transuranic Waste: Retrieve/move transuranic and alpha low-level waste to new compliant storage; treat offsite and onsite transuranic and alpha low-level waste; ship transuranic waste offsite for disposal; accept transuranic waste from offsite for treatment.

Low-Level Waste: Treat onsite and offsite; construct and operate additional treatment and disposal facilities onsite.

Mixed Low-Level Waste: Treat onsite by incineration and nonincineration; construct and operate facilities to treat waste by incineration and nonincineration; construct and operate disposal facility; ship waste offsite for treatment and disposal.

Greater-than-Class-C Waste: Receive sealed sources for recycle or storage; construct dedicated storage facility.

Hazardous Waste: Ship offsite for treatment, storage, and disposal.

\section{Alternative C (Minimum Treatment, Storage, and Disposal)}

Spent Nuclear Fuel: Ship Idaho National Engineering Laboratory spent nuclear fuel inventory to DOE Centralization site; continue to examine and store naval spent nuclear fuel during approximate three-year transition period; phase out spent nuclear fuel handling facilities; demonstrate actinide recycle at Argonne National Laboratory-West.

Environmental Restoration: Conduct all planned projects for all Waste Area Groups; decontaminate and decommission Auxiliary Reactor Area (ARA)-II, and Boiling Water Reactor Experiment (BORAX)-V; focus on institutional controls to the extent possible for cleanup projects; clean up groundwater and vadose zone; clean up buried waste and Idaho Chemical Processing Plant; retrieve and treat Pit 9 wastes.

High-Level Waste: Select technology and construct immobilization facility to start operation in 2015; select technology and develop treatment to minimize volume of high-activity waste; construct replacement liquid storage tanks.

Transuranic Waste: Retrieve/move transuranic and alpha low-level waste to new compliant storage; ship transuranic waste offsite for disposal; ship waste to offsite DOE facility for storage.

Low-Level Waste: Ship to other DOE facilities for treatment, storage, and disposal.

Mixed Low-Level Waste: Ship offsite for treatment, storage, and disposal.

Greater-than-Class-C Waste: Discontinue management programs.

Hazardous Waste: Ship offsite for treatment, storage, and disposal. 


\section{Alternative D (Maximum Treatment, Storage, and Disposal)}

Spent Nuclear Fuel: Examine and store naval spent nuclear fuel; receive DOE spent nuclear fuel; expand storage capacity in pools at Building 666 of the Idaho Chemical Plant; phase in expanded dry storage; phase out storage pools; at Building 603 of the Idaho Chemical Processing Plant; phase in spent nuclear fuel stabilization; demonstrate actinide recycle.

Environmental Restoration: Conduct planned projects for all waste area groups; decontaminate and decommission Auxiliary Reactor Area (ARA)-II, Boiling Water Reactor Experiment (BORAX)-V, Engineering Test Reactor, Materials Test Reactor, Fuel Processing Complex, Fuel Receipt/Storage Facility, Headend Processing Plant, Waste Calcine Facility, and Central Liquid Waste Processing Facility; focus on residential future land use to the extent possible for cleanup projects; clean up groundwater and vadose zone; clean up buried wastes and the Idaho Chemical Processing Plant; retrieve and treat Pit 9 wastes.

High-Level Waste: Convert liquid to calcine; select technology and construct immobilization facility to start operation in 2015; select technology and develop treatment to minimize high-activity waste; construct replacement liquid storage tanks.

Transuranic Waste: Retrieve/move transuranic and alpha low-level waste to new compliant storage; ship transuranic waste offsite for disposal; accept offsite transuranic waste; treat offsite and onsite transuranic waste and alpha low-level waste; dispose of alpha low-level waste at new onsite facility.

Low-Level Waste: Receive offsite waste; treat waste onsite; construct and operate additional treatment and disposal facilities onsite.

Mixed Low-Level Waste: Receive offsite waste; treat waste onsite by incineration and nonincineration; construct facilities for onsite incineration and nonincineration treatment; construct and operate new disposal facility; ship waste offsite for treatment and disposal.

Greater-than-Class-C Waste: Receive sealed sources for recycle or storage; construct dedicated storage facility.

Hazardous Waste: Ship waste offsite for treatment, storage, and disposal; possibly construct onsite treatment, storage, and disposal facility.

would be expanded to the extent needed to comply with regulations and agreements.

\section{Alternative D (Maximum Treatment, Storage, and Disposal)}

\author{
Under Alternative D (Maximum \\ Treatment, Storage, and Disposal), spent \\ nuclear fuel and waste would be \\ transferred from other DOE facilities to \\ the Idaho National Engineering \\ Laboratory for management to the \\ extent possible. Environmental \\ restoration activities would emphasize \\ residential use as the preferred end land \\ use, which potentially would result in \\ maximum waste generation.
}

Implementation of this alternative would require additional projects not yet defined or the expansion of identified projects [compared to Alternative B (Ten-Year Plan)].

Acceptance of waste and spent nuclear fuel from other sites would be maximized. Wastes generated from environmental restoration and waste management activities onsite would be increased over that of the other alternatives. Spent nuclear fuel and environmental restoration and waste management activities at the Idaho National Engineering Laboratory would be continued and enhanced to meet current and expanded spent nuclear fuel and waste handling needs. These

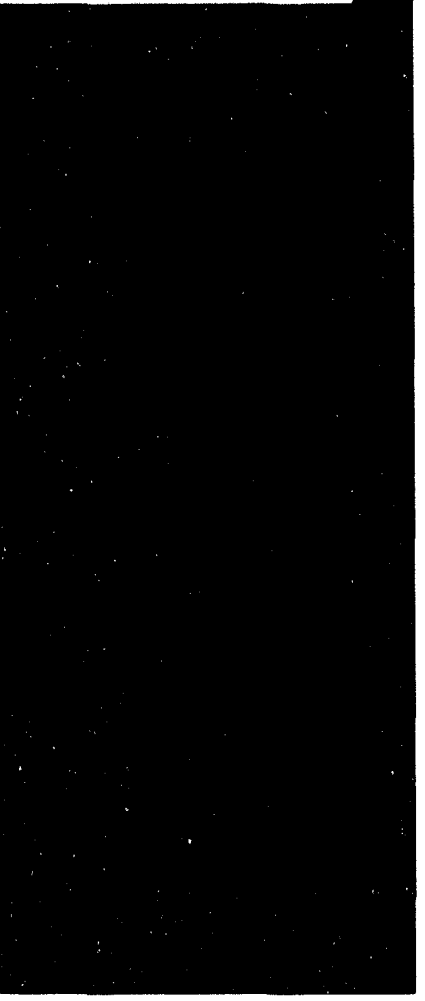




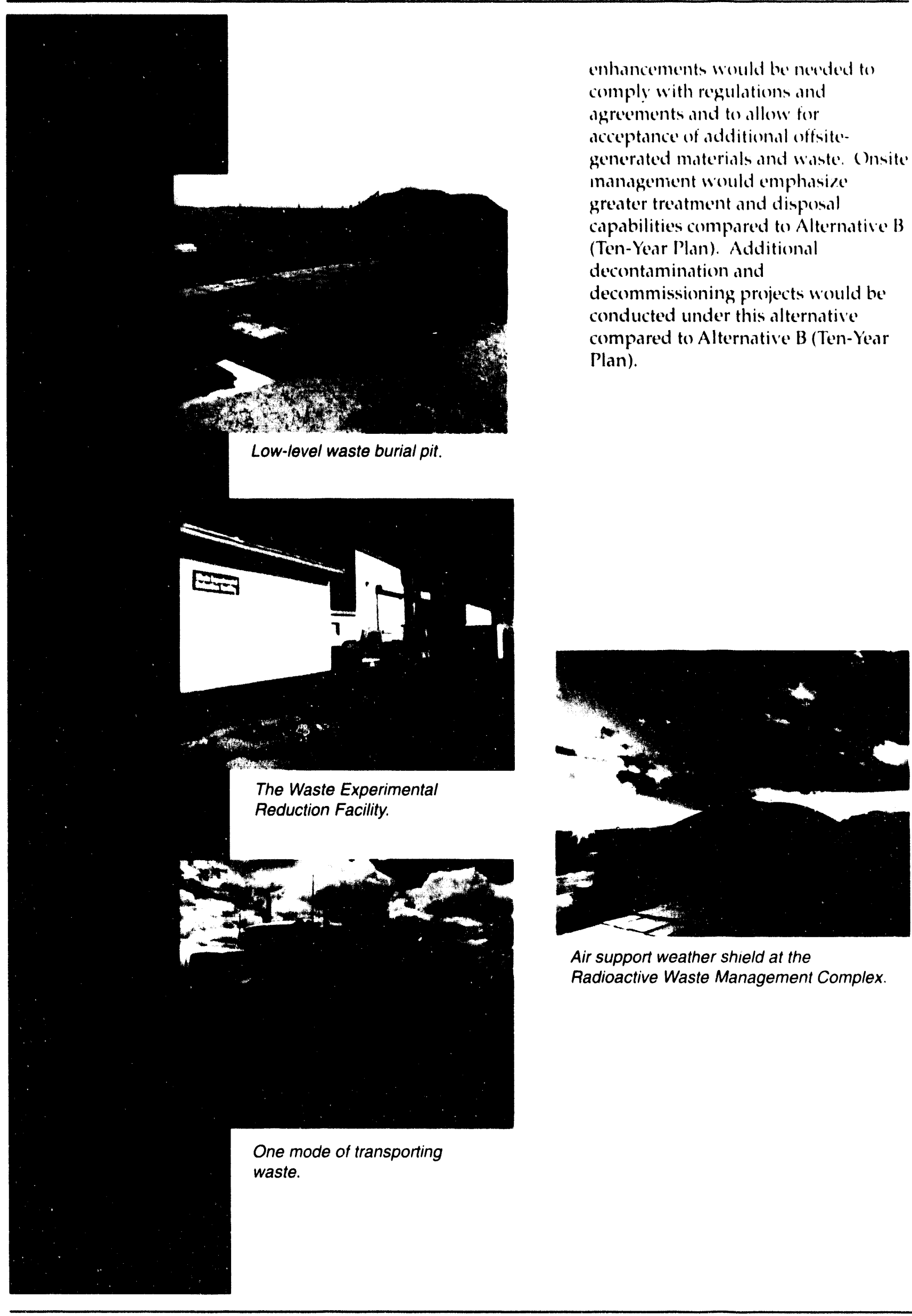


$T$ he Idaho National Engineering Laboratory is located on

2,304 square kilometers $(890)$ square miles) west of the City of Idaho Falls in southeast ldaho. The site sits on the Eastern Snake River Plain and is bordered by the Bitterroot, Lemhi, and Lost River mountain ranges. Local rivers and streams drain the mountain watersheds, but most surface water is diverted for irrigation before it reaches the site boundaries. Site activities do not directly affect surface water quality outside the site because current discharges from facilities go to seepage and evaporation basins or storm water injection wells.

The Idaho National Engineering Laboratory overlies the Snake River Plain Aquifer, the largest aquifer in Idaho. Subsurface water quality near the site is affected by natural water chemistry and contaminants originating at the site. Previous waste discharges to unlined ponds and deep wells have introduced radionuclides, nonradioactive metals, inorganic salts, and organic compounds into the subsurface. Because of improved waste management practices, these discharges no longer occur and groundwater quality continues to improve. Only extremely low concentrations of radioactive iodine (iodine-129) and tritium have ever migrated beyond the site boundary; tritium no longer migrates offsite and iodine-129 concentrations are well below maximum contaminant levels (upper allowable limit in drinking water) established by the U.S. Environmental Protection Agency.

Idaho National Engineering Laboratory activities result in radiological air emissions; however, these are very low (less than background radiation) and well within standards. Nonetheless, Idaho National Engineering Laboratory workers may be exposed to radiation through their work. Those who may receive more than 0.1 rem per year (DOE's administrative limit is 2.(1) rem) are monitored. About 32 percent of workers monitored between 1987 and 1991 received measurable radiation doses.

The Idaho National Engineering Laboratory primarily consists of open, undeveloped land covered predominantly by sagebrush and grasslands with animal communities typical of these vegetation types. Two Federal endangered and six candidate animal species have the potential for occurring, and seven animal species of special concern (State listing) occur at the ldaho National Engineering Laboratory. Ten plant species identified as sensitive, rare, or unique by other Federal agencies and the Idaho Native Plant Society also occur at the Idaho National Engineering Laboratory. Radionuclides have been found above background levels in individual plants and animals adjacent to facilities, but not at the population, community, or ecosystem levels.

The Idaho National Engineering Laboratory site has a varied inventory of cultural resources. These include fossil localities, prehistoric archaeological sites, historic sites, areas important to Native American people for religious and traditional reasons,

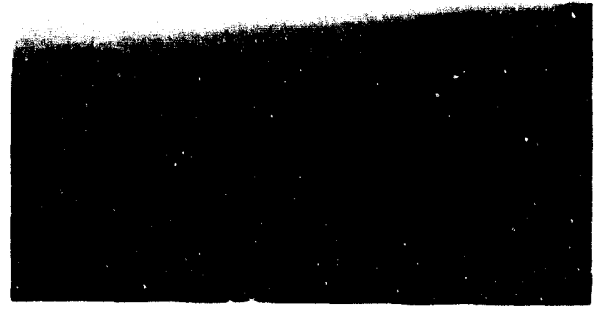

View of the Snake River Plain.

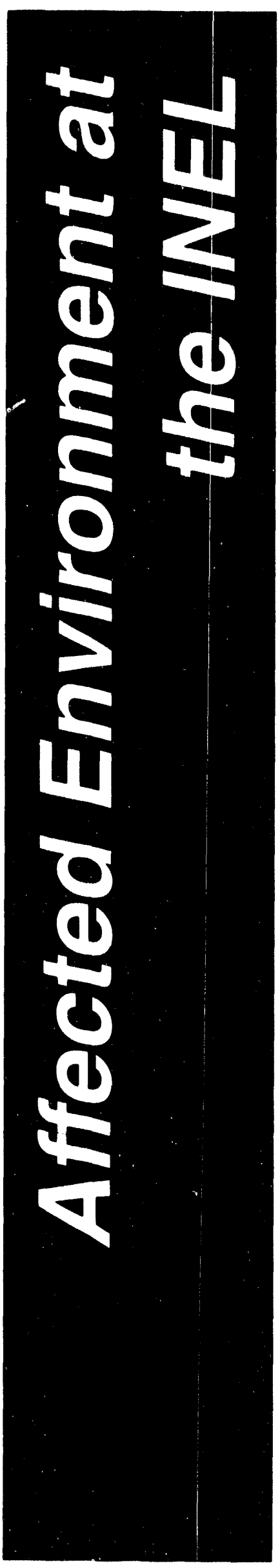


and facilities associated with the development of nuclear science in the United States.

Most land within the site boundaries is used for grazing or is general open space. Only about 2 percent of the 2,304 square kilometers (890 square miles) is used for facilities and operations, with another 5 percent devoted to public roads and utility rights-of-way. Over 97 percent of Idaho National Engineering laboratory empleneses lise in the seven counties surrounding the site. The regional economy relies on farming, ranching, and mining. The Idaho National Engineering Laboratory acounts for almost 12 percent of the total regional employment. Nearly half of ldaho National Engineering Laboratory's budget of $\$ 1$ billion is devoted to environmental restoration and waste management. 
he environmental consequences of the site-specific alternatives have

been assessed for the Idaho National Engineering Laboratory and the surrounding region. The environmental impact analyses are based on conservative assumptions (that is, imparts are usually overestimated). Analytical approaches are designed to be a reasonable projection of the maximum reasonably foreseeable consequences. The potential effects of each alternative were estimated by evaluating each individual project proposed for the alternative, summing the projects' collective effects under each alternative, and including interactions among the individual projects that compose each alternative. Cumulative impacts were determined. by evaluating past, present, and reasonably foreseeable future actions of DOE and non-DOE projects or activities, in combination with the alternatives.

Although the impact to each environmental discipline (for example, land use or employment) is assessed in greater detail in Volume 2, this Summary focuses on potential adverse impacts that DOE has found to be of greater interest to the public, as demonstrated through the scoping process and other public involvement programs at the Idaho National Engineering Laboratory.

\section{Air Quality}
Atmospheric visibility has been specifically designated as an air-quality- related value under the 1977 Prevention of Significant Deterioration
Amendments to the Clean Air Act. A U.S. Environmental Protection Agency developed computer code was used to conservatively estimate potential visibility impacts at the nearby Craters of the Moon Wilderness Area
[20 kilometers (12 miles) southwest of the Idaho National Engineering Laboratory]. The code calculates contrast and color shift for two assumed plume-viewing backgrounds-the

horizon sky and a dark terrain object.

The results indicate that for all alternatives, the potential for visual impacts at Craters of the Moon Wilderness Area without the use of mitigation measures cannot be ruled out. Use of more refined visibility models could yield more favorable results, although it is likely that additional facility controls would still be required. DOE would mitigate the potential effects and ensure that visibility is not impaired by using combustion control equipment and other best available control technologies as required.

Conservative modeling analyses were also performed to assess the potential impacts from radionuclides, toxic pollutants (for example, mercury) and criteria pollutants (for example, particulates). The results indicate, under Alternatives B (Ten-Year Plan) and $D$ (Maximum Treatment, Storage, and Disposal), that projected concentrations of mercury levels at the site boundary would be equal to (Alternative B) or about 10 percent higher (Alternative D) than the recently promulgated State of Idaho standard of 1 microgram per cubic meter. Hydrochloric acid levels at the maximum site boundary and public road locations would be about two-thirds of the applicable standard of 7.5 micrograms per cubic meter for both Alternatives $B$ and D. The cumulative effects of baseline conditions and impacts of Alternatives $B$ and $D$ result in levels of hydrochloric acid at the maximum public road location that would be about one-third higher than the standard. These cumulative effects are reported for information purposes only, since the standard only applies to emissions from new (and not existing) facilities.

Projected levels of toxic air pollutants at onsite locations would 


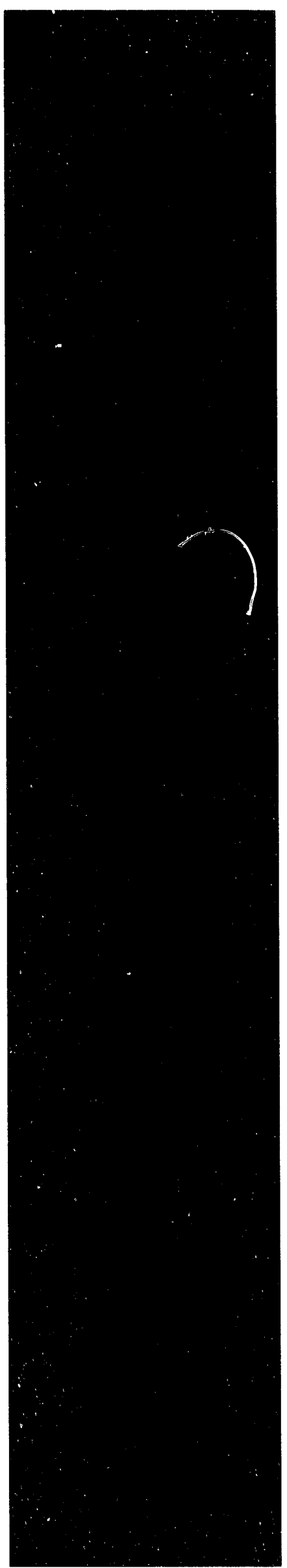

be well below occupational exposure limits established for protection of workers. Administrative controls, such as limits on waste stream feed rates and limits on total chloride content of waste materials, and other best available control technologies would be employed to minimize emissions. Under all alternatives, respirable (breathable) particulate concentrations and total suspended particulates (dust) (both from shortterm construction activities) are projected to exceed the 24-hour Federal standard (150 micrograms per cubic meter) and the State standard (260 micrograms per cubic meter), respectively. Standard construction practices (for example, watering) would be used to minimize dust generated by these activities.

The air quality was evaluated in light of past, present, and reasonably foreseeable future actions, including DOE projects not associated with the spent nuclear fuel, environmental restoration, and waste management programs, plus any offsite projects conducted by Government agencies, businesses, or individuals. This impact analysis found that the contribution to cumulative impacts from the alternatives would be low relative to other projects, and that concentrations of toxic and criteria pollutants at the site boundary would be less than the applicable standards.

\section{Cultural Resources}

Methods to identify, evaluate, and mitigate impacts to cultural resources have been established through the National Historic Preservation Act, as amended; the Archaeological Resource Protection Act; the Native American Graves Protection and Repatriation Act; and the American Indian Religious Freedom Act. Potential impacts to cultural resources were assessed by identifying project activities that could affect known or expected significant resources and determining whether a project activity would have an effect on significant resources. A project would affect a significant resource if it would alter the resource's characteristics.

Because some projects are not yet fully defined, the impacts to cultural resources cannot be completely identified. The impacts to cultural resources would be dependent upon

(a) the amount of surface disturbance [ranges from about 40 acres (0.16 square kilometer) under Alternative A (No Action) to about 1,100 acres (4.4 square kilometers) under Alternative D (Maximum Treatment, Storage, and Disposal)]; (b) the degree to which these areas have been surveyed for resources and the number of potentially affected structures [ 9 for Alternatives A (No Action) and $C$ (Minimum Treatment, Storage, and Disposal), and 66 for Alternatives B (Ten-Year Plan) and $D$ (Maximum Treatment, Storage, and Disposal)]; and (c) the number of known cultural resource sites (23 for Alternatives $B$ and D). For any alternative, DOE would conduct detailed pre-construction surveys and would consult with the State Historic Preservation Office and Native American Groups before any undertaking to determine the appropriate measures to minimize impacts to significant resources.

Because Native American people hold the land sacred, in their terms the entire Idaho National Engineering Laboratory is culturally important. This includes all prehistoric archeological sites, some of which are important in a religious or cultural heritage context, as well as certain features of the natural landscape that may contain important natural resources or have special significance. Geographically, the Idaho National Engineering Laboratory site is included within a large territory once inhabited by and still of importance to the Shoshone-Bannock Tribes. 


\section{Ecology}

The ldaho National Engineering Laboratory primarily consists of open, undeveloped land covered predominantly by sagebrush and grasslands with animal communities typical of these vegetation types. Radionuclides have been found above background levels in individual plants and animals adjacent to facilities, but not at the population, community, or ecosystem levels.

Under Alternatives A (No Action) and $C$ (Minimum Treatment, Storage, and Disposal), limited environmental restoration activities would be undertaken, resulting in the long-term presence of radioactive and hazardous wastes in the environment. Plants and animals would continue to be exposed to these wastes. Alternatives B (TenYear Plan) and D (Maximum Treatment, Storage, and Disposal) would result in a decrease in radioactive uptake over the long-term as environmental restoration activities proceed.

Implementation of any alternative would result in the loss of habitat from facility modification and construction. Alternative D (Maximum Treatment, Storage, and Disposal) would have the greatest estimated consequence, claiming about 1,100 acres (4.4 square kilometers) of additional habitat, of which 840 acres (3.4 square kilometers) would be newly disturbed, and 230 acres ( 0.93 square kilometer) would be revegetated, resulting in a net loss of about 890 acres (3.6 square kilometers). Alternative A (No Action) would have the least relative impact, disturbing only about 40 acres ( 0.16 square kilometer) of habitat, 5 acres ( 0.02 square kilometer) of which would be newly disturbed.

Estimated habitat loss from each alternative was assessed in light of other DOE and non-DOE projects. When these projects were considered together, it was estimated that Alternative A (No
Action) would disturb 310 acres (1.23 square kilometers), followed by Alternatives C (Minimum Treatment, Storage, and Disposal) [550 acres (2.2 square kilometers)], B (Ten-Year Plan) $[2,200$ acres (8.9 square kilometers)], and $\mathrm{D}$ (Maximum Treatment, Storage, and Disposal) [3,000 acres (12 square kilometers)]. To minimize habitat loss, DOE would conduct surveys and consult with appropriate Federal and State agencies before facility construction or modification. If necessary, current project planning would be modified to minimize surface disturbances.

\section{Groundwater Quality}

Previous operations have introduced radionuclides, nonradioactive metals, inorganic salts, and organic compounds into the subsurface.

Radionuclide concentrations in the Snake River Plain Aquifer beneath the site have generally decreased since the mid 1980s because of changes in disposal practices, radioactive decay, adsorption of radionuclides to rocks and minerals, and dilution by natural surface water and groundwater entering the aquifer. Extremely low concentrations of iodine-129 and tritium have migrated outside of site boundaries. Although nonradioactive metals, inorganic salts, and organic compounds have been detected in the aquifer, none

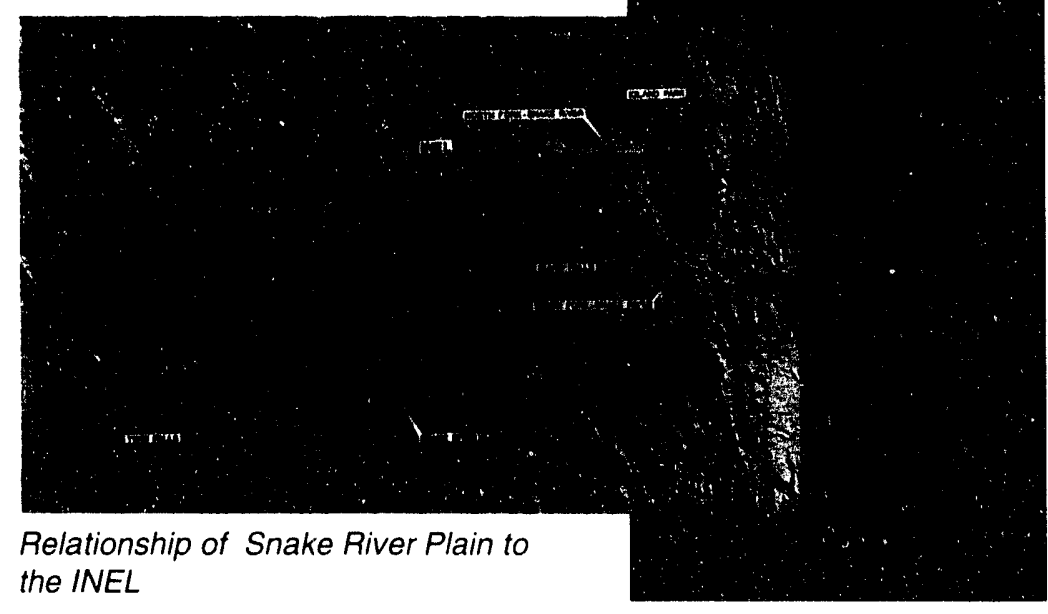




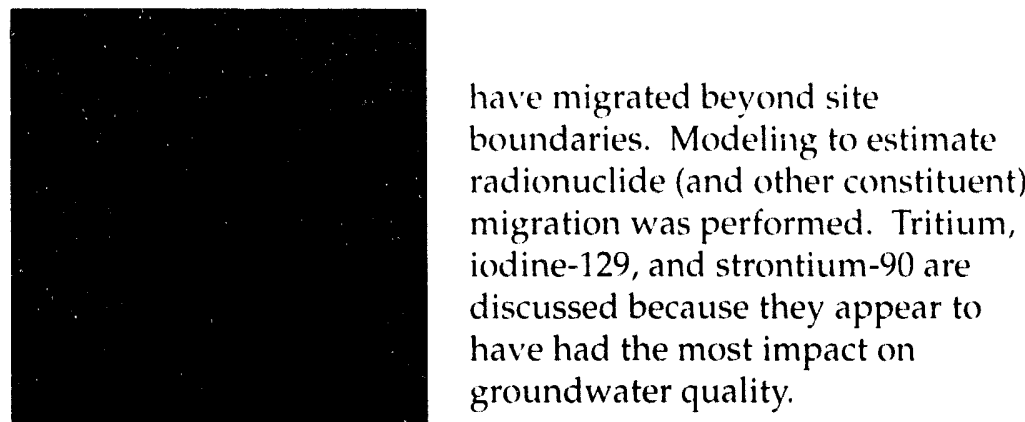

Drinking water at the Idaho National Engineering Laboratory site may contain small concentrations of tritium, strontium-90, and iodine- 129 . Over a 50-year working period, this radioactivity could result in about a 20-millirem dose to an individual worker. This radiation dose is well within regulatory limits and is very small compared to other sources of occupational radiation exposure.

\section{Normal Operations Impacts}

Potential impacts from any alternative would occur to workers and the public from exposures to radiation during routine operations of facilities and during routine transportation of spent nuclear fuel and radioactive waste. Additional radiation impacts could also occur as the result of accidents at facilities or during transportation.

\section{Facilities}

Idaho National Engineering Laboratory facilities release small amounts of radionuclides to the air in levels that are within regulatory standards. Estimates of latent cancer fatalities are based on exposures to 10 years of Idaho National Engineering Laboratory operations under each alternative. The likelihood of the maximally exposed worker contracting a fatal cancer ranges from about 1 chance in 40,000 [Alternative D (Maximum Treatment, Storage, and Disposal)] to about 1 chance in 1,000,000 [Alternative A (No Action)]. For the maximally exposed member of the public living offsite, the likelihood ranges from 1 chance in 200,000 [Alternative D
(Maximum Treatment, Storage, and Disposal)] to about 1 chance in $1,000,000 \mid$ Alternatives $\mathrm{A}$ and $\mathrm{C}$ (Minimum Treatment, Storage, and Disposal)]. In the nearby population of about 132,000 , it is estimated that less than one latent cancer fatality would occur in the 10-year period for all alternatives.

\section{Workers}

Impacts to workers at the Idaho National Engineering Laboratory from routine occupational hazards were also assessed. It is estimated that routine exposure to radiation would result in an estimated 1.0 latent cancer fatality [Alternative A (No Action)] to 1.1 [Alternatives B (Ten-Year Plan) and $D$ (Maximum Treatment, Storage, and Disposal)] additional latent cancer fatalities over 10 years of Idaho National Engineering Laboratory operations in a worker population of 9,255 to 10,288 .

These same populations of workers would also report between 3,100 and 3,600 occupationally-related injuries and illnesses over 10 years of Idaho National Engineering Laboratory operations. Work place hazards would be reduced by the worker and radiological-safety programs and regulatory standards currently in place.

\section{Transportation}

During the incident-free transportation of waste and spent nuclear fuel, the general population living and traveling along the transport route would be exposed to radiation from the passing shipments. Transportation workers would also be exposed. The total number of fatalities for the shipments would be the sum of the estimated number of radiationrelated latent cancer fatalities for transportation workers and the general population and the estimated number of nonradiological fatalities from vehicular emissions. 
Over the 10-year period 1995 through 2005 , if waste shipments were made by truck, the estimated number of total fatalities would range from 0.10 to 1.4 . If waste shipments were made by rail, the estimated number of total fatalities would range from 0.02 to 0.3 .

Over the 40-year period 1995 through 2035 , if spent nuclear fuel shipments were made by truck, the estimated number of total fatalities would range from 0.06 to 1.6 . If spent nuclear fuel shipments were made by rail, the estimated number of total fatalities would range from 0.06 to 0.2 .

\section{Accidents}

A potential exists for accidents at facilities associated with the treatment, storage, and disposal of radioactive and hazardous materials. Accilents can be categorized into events that are abnormal (for example, minor spills), events that a facility was designed to withstand, and events that a facility was not designed to withstand (but whose impacts may be offset or mitigated). A range of accidents was considered and consequences were estimated for a member of the public at the nearest site boundary [for the population (about $132,000)$ within 50 miles] and for the workers. In addition, accident analyses were performed for the transport of spent nuclear fuel and radioactive waste.

\section{Facilities}

The maximum reasonably foreseeable accident for facility operations, is the same among the alternatives and involves spent nuclear fuel. A severe earthquake damages a facility and causes spent nuclear fuel to melt, resulting in a radiological release. Although such an event is unlikely ( 1 chance in 100,000 years), the maximally exposed individual at the site boundary would incur an estimated risk of increased latent cancer fatalities of 1 chance in about 40 million. In the surrounding population of 132,000 this postulated accident could result in at most seven additional latent cancer fatalities.

\section{Workers}

The maximum reasonably foreseeable radiological accident for workers results from an earthquake causing a facility collapse. This event has a likelihood of about one chance in 3,300 years. As many as 50 workers could be subjected to potentially fatal prompt exposures. Workers that survive the initial event could see increased risk of developing a latent fatal cancer to one chance in 90. The maximum reasonably foreseeable hazardous material accident results from an accidental release of the entire inventory of chlorine gas (a hazardous material) from a facility. The event has about one chance per 100,000 years and could cause fatalities to as many as 100 workers. Such a release also would be the maximum reasonably foreseeable hazardous material accident for public consequences, but no fatalities would be expected.

\section{Transportation}

During the shipment of waste and spent nuclear fuel, radiological accidents and traffic accidents could occur. To determine the accident risk from transporting waste and spent nuclear fuel, a complete spectrum of accidents was evaluated.

The estimated cumulative risk of a latent cancer fatality from radiological accidents would range from 1 in 1,300 to 1 in 340 for the period 1995 through 2005 if waste shipments were made by truck. The estimated cumulative accident risk from traffic accidents would range from 0.30 to 3.4 fatalities for the period 1995 through 2005.

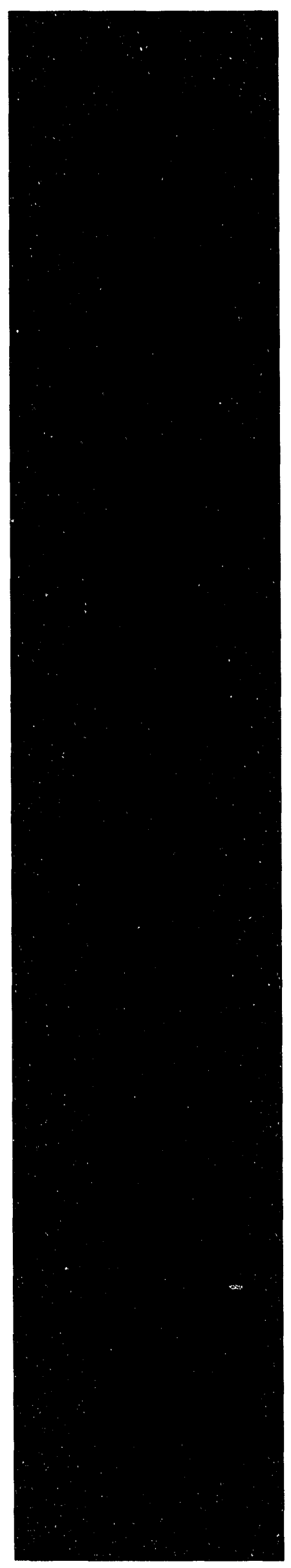


The estimated cumulative risk of a latent cancer fatality from radiological accidents would range from 1 in 17,000 to 1 in 2,900 for the period 1995 through 2005 if waste shipments were made by train. The estimated cumulative accident risk from traffic accidents would range from 0.003 to 0.04 fatalities for the period 1995 through 2005.

The estimated cumulative risk of a latent cancer fatality from radiological accidents would range from 1 in 240,000 to 1 in 830 for the period 1995 through 2035 if spent nuclear fuel shipments were made by truck. The estimated cumulative accident risk due to traffic accidents would range from 0.047 to 1.0 fatalities for the period 1995 through 2035.

The estimated cumulative risk of a latent cancer fatality from radiological accidents would range from 1 in 240,000 to 1 in 1,800 for the period 1995 through 2035 if spent nuclear fuel shipments were made by train. The estimated cumulative accident risk from traffic accidents would range from 0.047 to 0.85 fatalities for the period 1995 through 2035.
The consequences for various maximum foreseeable accidents also were evaluated for spent nuclear fuel and waste. The maximum foreseeable accident for spent nuclear fuel or waste shipments was for a rail shipping cask containing special-case commercial spent nuclear fuel. This hypothetical accident, which was estimated to have a probability of about 1 in 10 million, was estimated to result in 55 radiationrelated latent cancer fatalities.

Development of DOE's environmental justice implementation strategy is currently in progress, and appropriate results will be incorporated into the final EIS. Although the analysis in this draft EIS indicates there are no significant impacts from normal operations to any member of the general public, it is uncertain whether any low-income or minority

communities may be disproportionately located along the designated transportation corridors. The public comment period will provide an opportunity to obtain additional information in this regard. Further analysis is planned to be included in the EIS, as appropriate and practicable. 
OE is committed to operating the Idaho National Engineering Laboratory in compliance with all applicable environmental laws, regulations, executive orders, $\mathrm{DOE}$ orders, and permits and compliance agreements with regulatory agencies. To ensure compliance with permits and other applicable legal requirements, regulatory agencies conduct inspections at the Idaho National Engineering Laboratory. In addition, DOE has a comprehensive program for conducting internal audits or inspections and selfassessments, including periodic reviews conducted by interdisciplinary teams of experts. DOE has prepared and issued a site-specific environmental compliance planning manual. This manual contains step-by-step methods to maintain compliance with the various requirements of Federal and State agencies that regulate operations at the ldaho National Engineering Laboratory.

The DOE regulations that implement the National Environmental Policy Act require consultation with other agencies, when appropriate, to incorporate any relevant requirements as early as possible in the process. During preparation of the EIS, DOE initiated consultation with Federal and State agencies. The U.S. Fish and Wildlife Service and the State Historic Preservation Office have responded to DOE's request for consultation. The information provided has been considered in the analyses of the EIS.

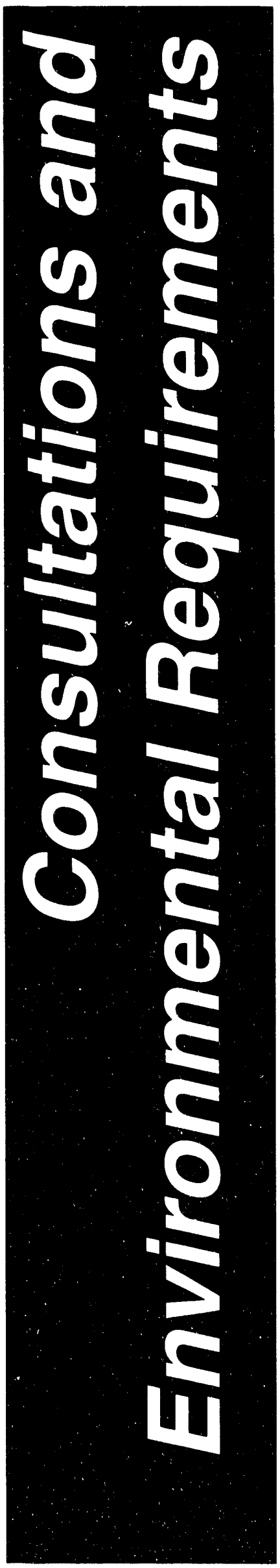





\section{Department of Energy Reading Rooms}

Public Reading Room for U.S. Department of Energy Headquarters

Room 1E-190, Forrestal Building

Freedom of Information Reading Room

1000 Independence Avenue, SW

Washington, DC 10585

(202) 586-6020

Monnay-Friday 9:00 a.m. to 4:00 p.m.

Public Reading Room for U.S.

Department of Energy

Oakland Operations Office

Environmental Information Center

1301 Clay Street, Room $700 \mathrm{~N}$

Oakland, CA 94612

(510) 637-1762

Monday-Friday 8:30 a.m. to 5:00 p.m.

Public Reading Room for U.S.

Department of Energy

Rocky Flats Operations Office

Front Range Community College Library

3645 W. 112th Ave

Level B, Center or the Building

Westminister, $\mathrm{CO} 80030$

(303) 469-4435

Monday and Tuesday 10:30 a.m. to 6:30 p.m. Wednesday 10:00 a.m. to $4: 00$ p.m., Thursday 8:00 a.m. to $4: 00$ p.m.

Public Reading Room for U.S.

Department of Energy

Idaho Operations Office

Public Reading Room

1776 Science Center Drive

Idaho Falls, ID 83402

(208) 526.9162

Monday-Friday 8:00 a.m. to 5:00 p.m.

Public Reading Room for U.S.

Department of Energy

University of lllinois at Chicago Library

Government Documents Section

801 South Morgan Street

Chicago, IL 60607

(312) 996-2738

Monday-Friday 8:00 a.m. to $10: 00$ p.m., Saturday 10:00 a.m. to $5: 00$ p.m.
Public Reading Room for U.S.

Department of Energy

National Atomic Museum

20358 Wyoming Boulevard, SE

Albuquerque, NM 87185

(505) 845-4378

Monday-Friday 9:00 a.m. to 5:00 p.m.

Public Reading Room for U.S.

Department of Energy

Nevada Operations Office

Coordination and Information Center

3084 South Highland Drive

P.O. Box 98521

Las Vegas, NV 89106

(702) 295-0731

Monday-Friday 7:00 a.m. to 4:00 p.m.

Public Information Room for U.S.

Department of Energy

Fernald Operations Office

Public Environmental Center

JANTER Building 10845

Hamilton-Cleves Highway

Harrison, $\mathrm{OH} 445030$

(513) 738-0164

Monday and Thursday 9:00 a.m. to 8:00 p.m., Tuesday, Wednesday, Friday 9:00 a.m. to 4:30 p.m., Saturday 9 a.m. to 1 p.m.

Public Reading Room for U.S.

Department of Energy

Savannah River Operations Office

Public Reading Room

Road 1A, Building 703A, D232

Aiken, SC 29802

(803) 725-1408

Monday-Thursday 8:00 a.m. to 11:00 p.m., Friday 8:00 a.m. to 5:00 p.m., Saturday 10:00 a.m. to $5: 00$ p.m., Sunday 2:00 p.m. to 11:00 p.m.

Public Reading Room for U.S.

Department of Energy

Oak Ridge Operations Office

Public Reading Room

55 Jefferson Avenue

Oak Ridge, TN 37831

(615) 576-1216

Monday-Friday 8:00 a.m. to $11: 30$ a.m. and $12: 30$ p.m. to $5: 00$ p.m.

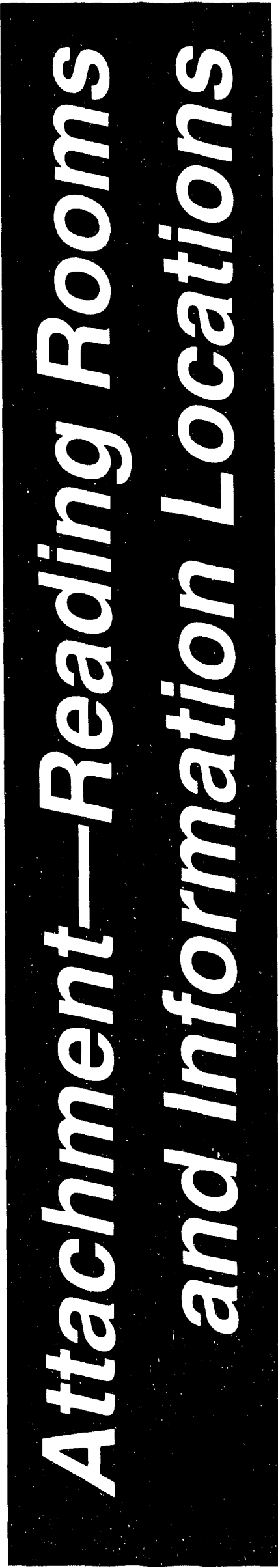


Public Reading Room for U.S.

Department of Energy

Richland Operations Office

Washington State University Tri-Cities

100 Sprout Road, Room 130 West

Richland, WA 99352

(509) 376-8583

Monday-Friday 8:00 a.m. to $12: 00$ p.m. and

1:00 p.m. to 4:00 p.m.

\section{Navy Information Locations}

Norfolk Naval Shipyard

\section{Chesapeake Central Library}

298 Cedar Rd.

Chesapeake, VA 23320-5512

(804) $436-8300$

Monday-Thursday 9:00 a.m to 9:00 p.m., Friday and Saturday 9:00 a.m to 5:00 p.m., Sunday 1:00 p.m to s:00 p.m.

\section{Newport News Public Library \\ Grissom Branch \\ 366 Deshazor Dr. \\ Newport News, VA 23602 \\ (804) 886-7896 \\ Monday-Thursday 9:00 a.m. to 9:00 p.m., Fri- day and Saturday 9:00 a.m. to 6:00 p.m.}

\section{Kiln Library}

301 East City Hall Ave.

Norfolk, VA 23510

(804) 441-2429

Monday-Thursday 9:00 a.m. to 9:00 p.m., Friday $9: 00$ a.m. to $5: 00$ p.m., Saturday

9:00 a.m. to 5:00 p.m.

Hampton Public Library

4207 Victoria Boulevard

Hampton, VA 23669

(804) 727-1154

Monday-Thursday 9:00 a.m. to 9:00 p.m., Friday and Saturday 9:00 a.m. to 5:00 p.m.

\section{Portsmouth Public Library}

Main Branch

601 Court St.

Portsmouth, VA 23704

(804) 393-8501

Monday-Thursday 9:00 a.m to 9:00 p.m, Friday and Saturday 9:00 a.m to 5:00 p.m.
Virginia Beach Central Library

4100 Virginia Beach Blvd.

Virginia Beach, VA 23452

(804) 431-3001

Monday-Thursday 10:00 a.m. to 9:00 p.m.

Friday and Saturday 10:00 a.m. to

5:00 p.m.. Sunday 1:00 p.m. to 5:00 p.m.

\section{Puget Sound Naval Shipyard}

\section{Kitsap Regional Library \\ 1301 Sylvan Way}

Bremerton, WA 98310

(206) 377.7601

Monday-Thursday 9:30 a.m. to 9:00 p.m.

Friday and Saturday 9:30 a.m. to 5:30 p.m.,

Sunday $12: 30$ p.m. to $5: 30$ p.m.

\section{Kitsap Regional Library}

Downtown Branch

6125 th Ave.

Bremerton, WA 98310

(206) 377-3955

Monday-Friday 10:00 a.m. to $6: 00$ p.m.

\section{Suzallo Library SM25}

University of Washington Libraries

University of Washington

Seattle, WA 98185

(206) 543-9158

Monday-Thursday 7:30 a.m. to $12: 00$ midnight, Friday $7: 30$ a.m. to 6:00 p.m., Saturday 9:00 a.m. to 5:00 p.m., Sunday

$12: 00$ p.m. to $12: 00$ midnight

\section{Portsmouth Naval Shipyard}

\section{Rice Public Library}

8 Wentworth Street

Kittery, ME 03904

(207) 439-1553

Monday-Wednesday, Friday 10:00 a.m. to 5:00 p.m., Thursday 10:00 a.m. to

8:00 p.m., Saturday 10:00 a.m. to 4:00 p.m.

\section{Portsmouth Public Library}

8 Islington Street

Portsmouth, $\mathrm{NH} 03801$

(804) 393-8501

Monday-Thursday 9:00 a.m. to 9:00 p.m., Friday and Saturday 9:00 a.m. to 5:00 p.m.

\section{Pearl Harbor Naval Shipyard}

Aiea Public Library 99-143 Monalua Rd

Aiea. HI 96701

(808) 488-2654

Monday and Thursday 10:00 a.m. to 8:00 p.m., Tuesday. Wednesday. Friday. Saturday 10:00 a.m. to 5:00 p.m.

\section{Hawaii State Library \\ 478 South King Street \\ Honolulu. HI 96813 \\ (808) 586-3535}

Monday, Wednesday, Friday, Saturday

9:00 a.m. to 5:00 p.m., Tuesday. Thursday 9:00 a.m. to $8: 00$ p.m.

\section{Pearl City Public Library \\ 1138 Waimano Home Rd. \\ Pearl City, HI 96782 \\ (808) $455-4134$}

Monday-Wednesday 10:00 a.m. to 8:00 p.m., Thursday-Saturday 10:00 a.m. to 5:00 p.m., Sunday $1: 00$ p.m. to $5: 00$ p.m.

\section{Pearl Harbor Naval Base Library Code 90L \\ 1614 Makalapa Dr. \\ Pearl Harbor, HI 96860-5350 \\ (808) 471.8238}

Tuesday-Thursday $10: 00$ a.m. to 7:00 p.m., Friday and Saturday 9:00 a.m. to 5:00 p.m.

\section{Kesselring Site}

\section{Albany Public Library}

Reference and Adult Services

161 Washington Ave.

Albany, NY 12210

(518) 449-3380

Monday-Thursday 9:00 a.m. to 9:00 p.m., Friday 9:00 a.m to 6:00 p.m., Saturday 9:00 a.m. to $5: 00$ p.m.

\section{Saratoga Springs Public Library} 320 Broadway

Saratoga Springs, NY 12866

(518) 584-7860

Monday-Thursday 9:00 a.m. to 9:00 p.m., Friday $9: 00$ a.m. to $6: 00$ p.m., Saturday 9:00 a.m. to $5: 00$ p.m., Sunday 1:00 p.m. to 5:00 p.m. 
Schenectady County Library

99 Clinton Street

Schenectady. $N \backslash 12305$

(518) 388-4511

Monday-Thursday, 9:00 a.m. to 9:00 p.m., Friday-Saturday, 9:00 a.m. to 5:00 p.m., Sun. day $1: 00$ p.m. to $5: 00$ p.m.

\section{Other Locations}

Main Library
University of Arizona
Tucson, AZ 85721
(602) $621-6433$
Sunday-Thursday 8:00 a.m. to 1:00 a.m., Fri-
day-Saturday 9:00 a.m. to 5:00 p.m.

\section{Main Library}

University of California at Irvine

Government Publications Receiving Dock Irvine, CA 92717

(714) 856-7290

School Hours: Monday-Thursday 8:00 a.m. to $7: 00$ p.m., Friday 8:00 a.m. to 5:00 p.m., Saturday and Sunday 1:00 p.m. to 11:00 p.m. Summer Hours: Monday-Friday 8:00 a.m. to 5:00 p.m., Saturday and Sunday 1:00 p.m. to $5: 00$ p.m.

\section{Pleasanton Public Library - Reference \\ Desk \\ 400 Old Bernal Avenue \\ Pleasanton, CA 94566 \\ (510) 462-3535}

Monday and Tuesday 1:00 p.m. to 8:00 p.m., Wednesday and Thursday 10:00 a.m. to 6:00 p.m., Saturday 2:00 p.m. to 6:00 p.m., Sunday 1:00 p.m. to 5:00 p.m.

\section{San Diego Public Library \\ 820 "E" Street \\ San Diego, CA 92101 \\ (619) 236-5867}

Monday-Thursday 10:00 a.m. to 9:00 p.m., Friday and Saturday 9:30 a.m. to 5:30 p.m., Sunday 1:00 p.m. to 5:00 p.m.

\section{Denver Public Library}

1357 Broadway

Denver, CO 80203

(303) 640-8845

Monday-Wednesday 10:00 a.m. to 9:00 p.m. Thursday-Saturday 10:00 a.m. to 5:30 p.m., Sunday 1:00 p.m. to 5:00 p.m.
George A. Smathers Libraries, Library West

University of Florida Library. Room 241

P.O. Box 117001

Gainesville. FL 32611-7001

(904) 392-0367

Monday-Thursday 8:00 a.m. to 9:30 p.m. Friday 8:00 a.m. to 5:00 p.m., Sunday

2:30 p.m. to $9: 30$ p.m.

\section{Atlanta Public Library}

1 Margaret Mitchell Square

Atlanta, GA 30303

(404) $730-1700$

Monday 9:00 a.m. to 6:00 p.m.. TuesdayThursday $9: 00$ a.m. to $8: 00$ p.m., Fiday 9:00 a.m. to 5:00 p.m., Saturday 10:00 a.m. to $5: 00$ p.m.

\section{Reese Library}

Augusta College

2500 Walton Way

Augusta, GA 30904-2200

(706) $737-1744$

School Hours: Monday-Thursday 7:45 a.m. to $10: 30$ p.m., Friday 7:45 a.m. to 5:00 p.m., Saturday 9:00 a.m. to 5:00 p.m. Sunday 1:30 p.m. to $9: 30$ p.m. Summer Hours: Monday-Friday 8:00 a.m. to 5:00 p.m.

\section{Chatham-Effingham-Liberty \\ Regional Library \\ 2002 Bull Street}

Savannah, GA 31401

(912) 234-5127

Monday-Thursday 9:00 a.m. to 9:00 p.m., Friday 9:00 a.m. to $6: 00$ p.m., Saturday 10:00 a.m. to $6: 00$ p.m.

\section{Parks Library}

lowa State University

Government Publications Department

Ames, IA 50011-2140

(515) 294-3642

School Hours: Monday-Thursday 7:30 a.m. to $12: 00$ midnight, Friday $7: 30$ a.m. to 10:00 p.m., Saturday 10:00 a.m. to 10:00 p.m., Sunday 12:30 p.m. to 12:00 midnight, Summer Hours: MondayThursday 7:30 a.m. to 10:00 p.m., Friday 7:30 a.m. to 5:00 p.m., Saturday 12:30 p.m. to $5: 00$ p.m., Sunday $12: 30$ p.m. to 10:00 p.m.
Boise Public Library

715 South Capitol Boulevard

Boise. ID 83702

(208) 384-4023

Monday-Friday $10: 00$ a m to $6: 00 \mathrm{p} . \mathrm{m}$ Tuesday-Thursday $10: 00 \mathrm{a} . \mathrm{m}$. $109.00 \mathrm{p.m}$. Saturday $1: 00$ p.m. $105: 00$ p.m

Idaho Department of Health and Welfare Idaho National Engineering Laboratory Oversight Program Library

1410 North Hilton

Boise. ID 83706

(208) 334.0498

Monday-Friday 8:00 a.m. to

5:00 p.m.

Idaho State Library

325 West State Street

Boise, ID 83702

(208) 334-2152

Monday.Friday 9:00 a.m. to

5:00 p.m.

\section{Shoshone-Bannock Library}

Bannock and Pima Streets, HRDC Building Fort Hall, ID 83203

(208) 238-3882

Monday-Friday 8:00 a.m. to $4: 30$ p.m.

\section{Idaho Falls Public Library \\ 457 Broadway \\ Idaho Falls, ID 83402 \\ (208) 529-1462}

Monday-Thursday 8:00 a.m. to 7:00 p.m, Friday 8:00 a.m. to 5:00 p.m., Saturday

9:00 a.m. to 1:00 p.m.

\section{University of Idaho Library}

Rayburn Street

Moscow, ID 83844-2353

(208) 885-6344

Monday-Friday 8:00 a.m. to $12: 00$ midnight, Saturday 9:00 a.m. to $12: 00$ midnight. Sunday $10: 00$ a.m. to $12: 00$ midnight

\section{Pocatello Public Library}

812 East Clark Street

Pocatello, ID 83201

(208) 232-1263

Monday-Thursday 10:00 a.m. to 9:00 p.m. Friday and Saturday 10:00 a.m. to 6:00 p.m. 
Twin Falis Public Library

434 Second Street East

Twin Falls, ID 83301

(208) 733-2964

Monday-Thursday 10:00 a.m. to $6: 00 \mathrm{pm}$

Friday 10:00 a.m. to $5: 00$ p.m.. Saturday

12:00 p.m.to $5: 00$ p.m

\section{Main Library, Third Floor \\ University of Illinois \\ 801 South Morgan. Mail Code 234 \\ Chicago. IL 60607 \\ (312) 413-2594}

Monday-Thursday 7:30 a.m. to $10: 00 \mathrm{pm}$. Friday 7:30 a.m. 10 5:00 p.m. Saturday $10: 00$ a.m. $105: 00$ p.m. Sunday $1: 00$ p.m. to 9:00 p.m

\section{Documents Library, 200-D \\ University of Illinois \\ 1408 W. Gregory Drive \\ Urbana, IL 61801 \\ (217) 244-2060}

School Hours: Monday-Thursday 8:00 a.m to $12: 00$ midnight, Friday 8:00 a.m. 10 6:00 p.m., Saturday 9:00 a.m. to 6:00 p.m. Sunday 1:00 p.m. to $12: 00$ midnight, Summer Hours: Monday-Thursday 8:00 a.m. to 9:00 p.m., Friday 8:00 a.m. to 6:00 p.m., Sat urday $9: 00$ a.m. to 5:00 p.m.. Sunday 1:00 p.m. to $5: 00$ p.m

\section{Engineering Library}

Purdue University

West Lafayette. IN 47907

(317) 494-2871

School Hours: Monday-Friday 8:00 a.m. to 12:00 midnight. Saturday 9:00 a.m. to 5:00 p.m. Sunday 12:00 p.m. to 12:00 midnight. Summer Hours: Monday-Friday 8:00 a.m. $108: 00$ p.m

\section{Manhattan Public Library}

Julliette and Poyntz

Manhattan, KS 66502

(913) $776-4741$

Monday-Friday 9:00 a.m. to 9:00 p.m., Saturday 9:00 a.m. to $6: 00$ p.m., Sunday

2:00 p.m. $106: 00$ p.m.

\section{Massachusetts Institute of Technology Science Library \\ 160 Memorial Drive Bulding 14 \\ Cambridge. MA 02139 \\ (617) 253.5685}

Monday-Thursday 8.00 a m. to $12.00 \mathrm{mid}$ night. Friday and Saturday $8.00 \mathrm{a} . \mathrm{m}$ to 8.00 p m. . Sunday 12.00 p.m. to 12.00 midnight

\section{O'Leary Library}

University of Massachusetts

1 University Ave

Lowell. MA 01854

(508) 934-3205

School Hours: Monday-Thursday 7:30 a.m. to $11: 00$ p.m. Friday 7:30 a.m. to $5: 00$ p.m. Saturday $10: 00$ a.m. to $6: 00$ p.m. Summer Hours: Monday-Friday 8:30 a.m to 9:00 p.m. Sunday 2:00 p.m. $107: 00$ p.m

\section{Worcester Public Library}

3 Salem Square

Worchester, MA 01608

(508) 799-1655

Monday and Wednesday $12: 00$ p.m. 10 9:00 p.m., Tuesday 10:00 a.m. to 9:00 p.m.. Thursday-Saturday 10:00 a.m. to 5:30 p.m

\section{Bethesda Public Library}

7400 Arlington Road

Bethesda, MD 20814

(301) 986-4300

Monday-Thursday 10:00 a.m. to 8:30 p.m. Friday 10:00 a.m. to 5:00 p.m., Saturday 9:00 a.m. to 5:00 p.m., Sunday 1:00 p.m. to 5:00 p.m

\section{Gaithersburg Regional Library}

18330 Montgomery Village Avenue

Gaithersburg, MD 20879

(301) 840-2515

Monday-Thursday 10:00 a.m. to 8:30 p.m. Friday 10:00 a.m. to 5:00 p.m., Saturday 9:00 a.m. to $5: 00$ p.m. Sunday 1:00 p.m. to 5:00 p.m.

\section{Hyattsville Public Library \\ 6530 Adelph Road \\ Hyattsville. MD 20782 \\ (301) 779.9330}

Monday-Thursday $1000 \mathrm{am} 10900 \mathrm{pm}$ Friday $1000 \mathrm{am}$ to $600 \mathrm{pm}$. Saturday $1000 \mathrm{am}$ to $5.00 \mathrm{pm}$. Sunday $100 \mathrm{p} \mathrm{m}$ to 5:00 p.m

\section{Ann Arbor Public Library}

343 South 5 th Avenue

Ann Arbor. MI 48104

(313) 994-2333

Monday 10.00 a.m. 109.00 p.m. TuesdayFriday $9: 00$ a.m. $109: 00$ p.m. Saturday $9: 00$ a.m. 106.00 p.m. Sunday 1.00 p.m. 10 5:00 p.m.

\section{Zanhow Library}

Saginaw Valley State University 7400 Bay Road

University Center. MI 48710

(517) $790-4240$

School Hours: Monday-Thursday 8:00 a.m. to $11: 00 \mathrm{p} . \mathrm{m}$. Friday 8:00 a.m. to $4: 30 \mathrm{p} . \mathrm{m}$. Saturday $9: 00$ a.m. to 5:00 p.m. Sunday 1:00 p.m. $109: 00$ p.m. Summer Hours: MondayThursday $8: 00 \mathrm{a} . \mathrm{m}$. to $10: 30$ p.m.. Friday 8:00 a.m. to $4: 30$ p.m. Saturday $10: 00$ a.m. to $2: 00$ p.m. Sunday 1:00 p.m. to $5: 00$ p.m.

\section{Ellis Library}

University of Missour!

Columbia, MO 65201

(314) 882-0748

School Hours: Monday-Thursday 7:30 a.m. to $12: 00$ midnight, Friday 7:30 a.m. to $11: 00$ p.m., Saturday 9:00 a.m. to 9:00 p.m., Sunday 12:00 p.m. to 1:00 a.m. Summer Hours. Monday and Thursday 8.00 a.m. 108.00 p.m. Tuesday, Wednesday, and Friday $8.00 \mathrm{a} . \mathrm{m}$. to $5: 00$ p.m. Saturday $12: 00$ p.m. to $5: 00$ p.m.

\section{Curtis Laws Wilson Library}

University of Missouri Library

Rolla, MO 65401-0249

(314) 341.4227

School Hours: Monday-Thursday 8:00 a.m. to $12: 00$ midnight. Friday 8:00 a.m. to 10:30 p.m. Saturday 8:00 a m. to 5:00 p.m. Sunday 2:00 p.m. to $12: 00$ midnight. Sum. mer Hours: Monday-Friday 8:00 a.m. to 10:00 p.m. Saturday 8:00 a m. to $5: 00$ p.m. Sunday $2: 00$ p.m. to $10: 00$ p.m. 
D.H. Hill LIbrary

North Carolina State University

P.O. Box 7111

Raleigh, NC 27695-7111

(919) 515-3364

School Hours: Monday-Thursday 7:00 a.m. to $1: 00$ a.m., Friday $7: 00$ a.m. to $6: 00$ p.m., Saturday 9:30 a.m. to 5:30 p.m.. Sunday

1:00 p.m. to 1:00 a.m. Summer Hours: Monday-Thursday 7:00 a.m. to 11:00 p.m., Friday 7:00 a.m. to 6:00 p.m.. Saturday $9: 30$ a.m. to $5: 30$ p.m., Sunday $1: 00$ p.m. to $11: 00 \mathrm{p} . \mathrm{m}$

\section{Omaha Public Library}

215 S. 15tr. Street

Omaha. NE 68102

(402) 444-4800

Monday-Thursday 9:00 a.m. 10 9:00 p.m., Friday and Saturday 9:00 a.m. to 5:30 p.m., Sunday 1:00 p.m. to $5: 00$ p.m.

\section{General Library}

University of New Mexico

Albuquerque. NM 87131.1466

(505) 277.5441

School Hours: Monday-Thursday 8:00 a.m. to $9: 00$ p.m. Friday 8:00 a.m. $105: 00$ p.m.. Saturday and Sunday 1:00 p.m. to 5:00 p.m., Summer Hours: Monday-Friday 8:00 a.m. to 6:00 p.m. Saturday 10:00 a.m. to 5:00 p.m.

\section{U.S. DOE Community Reading Room}

1450 Central Avenue. Suite 101

MS C314

Los Alamos, NM 87544

(505) 665.2127

Monday-Friday 8:00 a.m. to 5:00 p.m.

\section{Lockwood Lib:ary}

State University of New York-Buffalo

Buffalo. NY 14260-2200

(716) 645-2816

School Hours: Monday-Thursday 8:00 a.m. to $10: 45$ p.m.. Friday 8:00 a.m. to 9:00 p.m. Saturday $9: 00$ a.m. to 5:00 p.m., Sunday 1:00 p.m. io 10:45 p.m., Summer Hours: Monday, Wednesday. Thursday, and Friday 9:00 a.m. to 6:00 p.m., Tuesday 9:00 a.m. to 10:00 p.m. Sunday 1:00 p.m. to $9: 00$ p.m.
Engineering L.lbrary

Cornell University

Carpenter Hall. Main Floor

Ithaca. NY 14853

(607) 255.5762

School Hours: Monday.Thursday $8.00 \mathrm{a} . \mathrm{m}$ 10 $11: 00$ p.m. Friday 8:00 a.m. to 6:00 p.m. Saturday 10:00 a.m. 10 6:00 p.m. Sunday 12:00 p.m. to $11: 00$ p.m. Summer Hours Monday-Friday 8:00 a.m. to 6:00 p.m. Saturday $12: 00$ p.m. to $6: 00$ p.m.

\section{Cardinal Hayes Library}

Manhattan College

4531 Manhattan College Parkway

Riverdale. NY 10471

(718) 920-0100

School Hours: Monday-Thursday 8:00 a.m to $11: 00$ p.m. Friday 8:00 a.m. 10 6:30 p.m. Saturday 10:00 a.m. 10 5:00 p.m., Sunday 1:00 p.m. to $11: 00$ p.m., Summer Hours Monday-Friday 8:30 a.m. to 6:30 p.m.

\section{Brookhaven National Laboratory}

25 Brookhaven Avenue. Building 477 A P.O. Box 5000

Upton, NY 11973-5000

(516) 282.3489

Monday-Friday 8:30 a.m. to 9:00 p.m., Saturday and Sunday 10:00 a.m. to 6:00 p.m.

\section{Columbus Metropolitan Library}

96 South Grant Avenue

Columbus. $\mathrm{OH} 43215$

(614) 645-2710

Monday-Thursday 9:00 a.m. to 9:00 p.m. Friday and Saturday 9:00 a.m. to 6:00 p.m. Sunday 1:00 p.m. to 5:00 p.m.

\section{Kerr Library}

Oregon State University

Corvallis, OR 97331.4905

(503) 737-0123

Monday-Friday 7:45 a.m. to 2:00 a.m.. Saturday and Sunday 10:00 a.m. to 2:00 a.m.
Brantford Price Millar Library

Portland State University

934 S W Harrison

Portland. OR 97201

(503) 725.4617

Monday-Friday $8.00 \mathrm{am}$ to $10.00 \mathrm{p} . \mathrm{m}$. Saturday $10: 00$ a m. $1010: 00 \mathrm{pm}$. Sunday

11.00 a.m. 1010.00 p.m

\section{Pattee Library}

Pennsylvania State University University Park. PA 16801

(814) 865-2112

School Hours Monday-Thursday 8:00 a.m to $12: 00$ midnight. Friday $8: 00$ a.m. to 10.00 p.m. Saturday 8:00 a.m. $109: 00$ p.m., Sunday 1:00 p.m. to 12:00 midnight. Summer Hours: Monday.Thursday $7: 45 \mathrm{a} . \mathrm{m}$. to 10:00 p.m., Friday 7:45 a.m. to $9: 00$ p.m., Saturday 8:00 a.m. to $9: 00$ p.m. Sunday 1:00 p.m. to $10: 00$ p.m.

\section{Parragansett Public Library}

35 Kingston Road

Narragansett, RI 02882

(401) 789-9507

Monday 10:00 a.m. to 9:00 p.m., Tuesday. Friday 10:00 a.m. to $6: 00$ p.m., Saturday 10:00 a.m. to 5:00 p.m. (Saturday hours September to May only)

\section{Charleston County Main Library}

404 King Street

Charleston, SC 29403

(303) 723-1645

Monday-Thursday 9:30 a.m. to 9:00 p.m.. Friday-Saturday $9: 30$ a.m. to $6: 00$ p.m.. Sunday 2:00 p.m. to 6:00 p.m.

\section{South Carolina State Library \\ 1500 Senate Street \\ Columbia, SC 29201 \\ (803) $734-8666$}

Monday-Friday 8:15 a.m. to 5:30 p.m. Saturday $9: 00$ to $1: 00$ p.m.

\section{Clinton Public Library}

118 South Hicks Street

Clinton. TN 37716

(615) 457.0519

Monday and Thursday 10:00 a.m. 10 8:00 p.m. Tuesday. Wednesday. Friday. Salurday $10.00 \mathrm{a} . \mathrm{m}$ to $5.00 \mathrm{p} . \mathrm{m}$. 


Harriman Public Library
601 Waiden Street
Harriman. TN 37748
(615) $882 \cdot 3195$
Monday. Thursday $9: 00$ a.m. to $5: 00 \mathrm{p} \mathrm{m}$.
Friday-Saturday $9: 00$ a m to $100 \mathrm{p} . \mathrm{m}$.
Kingston Public Library
1000 Bradford Way Building $\# 3$
Kingston. TN 37763
(615) $376-9905$
Monday and Thursday $10: 00$ a.m. to
7:30 p.m. Tuesday. Wednesday. Friday
10:00 a.m. to $5: 30$ p.m. Saturday
10:00 a.m. $102: 00$ p.m.

Lawson McGhee Public Library

500 West Church Avenue

Knoxville. TN 37902

(615) 544-5750

Monday-Thursday 9:00 a.m. to $8: 30$ p.m., Friday 9:00 a.m. 10 5:30 p.m. Saturday and Sunday 1:00 p.m. 10 5:00 p.m.

\section{Oak Ridge Public Library}

Civic Center

Oak Ridge. TN 37830

(615) $482-8455$

Monday-Thursday 10:00 a.m. to 9:00 p.m.. Friday 10:00 a.m. to 6:00 p.m. Saturday 9:00 a.m. to $6: 00$ p.m. Sunday 2:00 p.m. to $6: 00$ p.m.

\section{Oliver Springs Public Library}

607 Easterbrook Avenue

Oliver Springs. TN 37840

(615) 435-2509

Tuesday-Thursday 2:00 p.m. $104: 00$ p.m., Saturday $9: 00$ a.m. to $12: 00$ midnight

\section{Rockwood Public Library}

117 North Front Avenue

Rockwood. TN 37854

(615) 354-1281

Monday. Wednesday. Friday and Saturday 10:00 a.m. to 5:00 p.m. Tuesday and Thurs. day 10:00 a.m. to 8:00 p.m.

\section{General Library \\ University of Texas \\ PCL 2 402X \\ Austin. TX 78713 \\ (512) 495.4262}

School Hours: Monday.Friday 8.00 a $\mathrm{m}$ to 2.00 a.m. Saturday 9.00 a m $102: 00$ a m. Sunday $12: 00 \mathrm{pm}$. to $2: 00 \mathrm{a} . \mathrm{m}$. Summer Hours Monday. Friday $8.00 \mathrm{a} \mathrm{m}$ to $10: 00 \mathrm{pm}$. Saturday $9.00 \mathrm{a} . \mathrm{m}$. to $10: 00 \mathrm{pm}$. Sunday $12: 00 \mathrm{pm}$ to $1000 \mathrm{p} . \mathrm{m}$.

\section{Evans Library}

Texas A\&M University. MS 5000

College Station. TX 77843.5000

(409) 845-8850

School Hours: Monday-Thursday 7:00 a.m. to $12: 00$ midnight. Friday $7: 00$ a.m. to 7:00 p.m. Saturday 9:00 a.m. 10 5:00 p.m. Sunday 1:00 p.m. to $11: 00$ p.m., Summer Hours: Monday-Thursday 7:00 a.m. to 11:00 p.m. Friday 7:00 a.m. to 7:00 p.m., Saturday $9: 00$ a.m. to $5: 00$ c.m. Sunday 1:00 p.m. $1011: 00$ p.m.

\section{Marriott Library}

University of Utah

Salt Lake City. UT 84112

(801) $581-8394$

School Hours: Monday-Thursday 7:00 a.m. to $11: 00$ p.m. Friday 7:00 a.m. 10 5:00 p.m. Saturday 9:00 a.m. to 5:00 p.m., Sunday 11:00 a.m. to $9: 00$ p.m. Summers Hours: Monday-Thursday 7:00 a.m. to 10:00 p.m., Friday 7:00 a.m. 10 5:00 p.m. Saturday 9:00 a.m. to 5:00 p.m. Sunday 1:00 p.m. to 5:00 p.m.

\section{Alderman Library}

University of Virginia

Charlottesville. VA 22903-2498

(804) 924-3133

School Hours: Monday-Thursday 8:00 a.m. to $12: 00$ midnight. Friday 8:00 a.m. to $6: 00$ p.m., Saturday 9:00 a.m. to $6: 00$ p.m.. Sunday $12: 00$ p.m. to $12: 00$ midnight. Summer Hours: Monday-Thursday 8:00 a.m. to $10: 00$ p.m. Friday $8: 00$ a.m. to $6: 00$ p.m., Satur. day $9: 00$ a.m. to $6: 00$ p.m. Sunday $2: 00$ p m. to 10.00 p.m.
Owen Science \& Engineering Library

Washıngton State University

Pullman. WA $99164-3200$

(509) 335.4181

School Hours. Monday-Thursday $8.00 \mathrm{a} \mathrm{m}$ to $1100 \mathrm{pm}$. Friday 800 a m $10900 \mathrm{pm}$ Saturday $1200 \mathrm{p} . \mathrm{m}$. $10900 \mathrm{p} \mathrm{m}$. Sunday 1200 p.m. to $11.00 \mathrm{p} \mathrm{m}$. Summer Hours Monday and Thursday $7.30 \mathrm{a} \mathrm{m}$. 10 $11.00 \mathrm{p} \mathrm{m}$. Tuesday. Wednesday, and $\mathrm{Fr}_{\mathrm{r}}$. day $7: 30$ a.m. 106.00 p.m. Saturday and Sunday $12: 00 \mathrm{pm}$. to $6: 00 \mathrm{pm}$

\section{Foley Center}

Gonzaga University

East 502 Boone Avenue

Spokane, WA 99258

(509) 328-4220. extension 3125

School Hours: Monday-Thursday 8:00 a.m. to $12: 00$ midnight. Friday and Saturday 8:00 a.m. $109: 00$ p.m. Sunday 11:00 a.m. to $12: 00$ midnight, Summer Hours: Monday. Friday 8:00 a.m. to 9:00 p.m. Saturday 10:00 a.m. to $6: 00$ p.m. Sunday 1:00 p.m. to $7: 00$ p.m.

\section{Madison Public Library}

201 W. Mittlin Street

Madison. WI 53703

(608) 266.6350

Monday-Wednesday 8:30 a.m. to 9:00 p.m. Thursday and Friday 8:30 a.m. to 5:30 p.m. Saturday 9:00 a.m. to 5:30 p.m.

\section{Teton County Public Library}

320 South King Street

Jackson. WY 83001

(307) 733-2164

Monday. Wednesday and Friday 10:00 a.m. to 5:30 p.m. Tuesday and Thursday 10:00 a.m. to 9:00 p.m. Saturday 10:00 a.m. to $5: 00$ p.m. Sunday 1:00 p.m. to 5:00 p.m. 

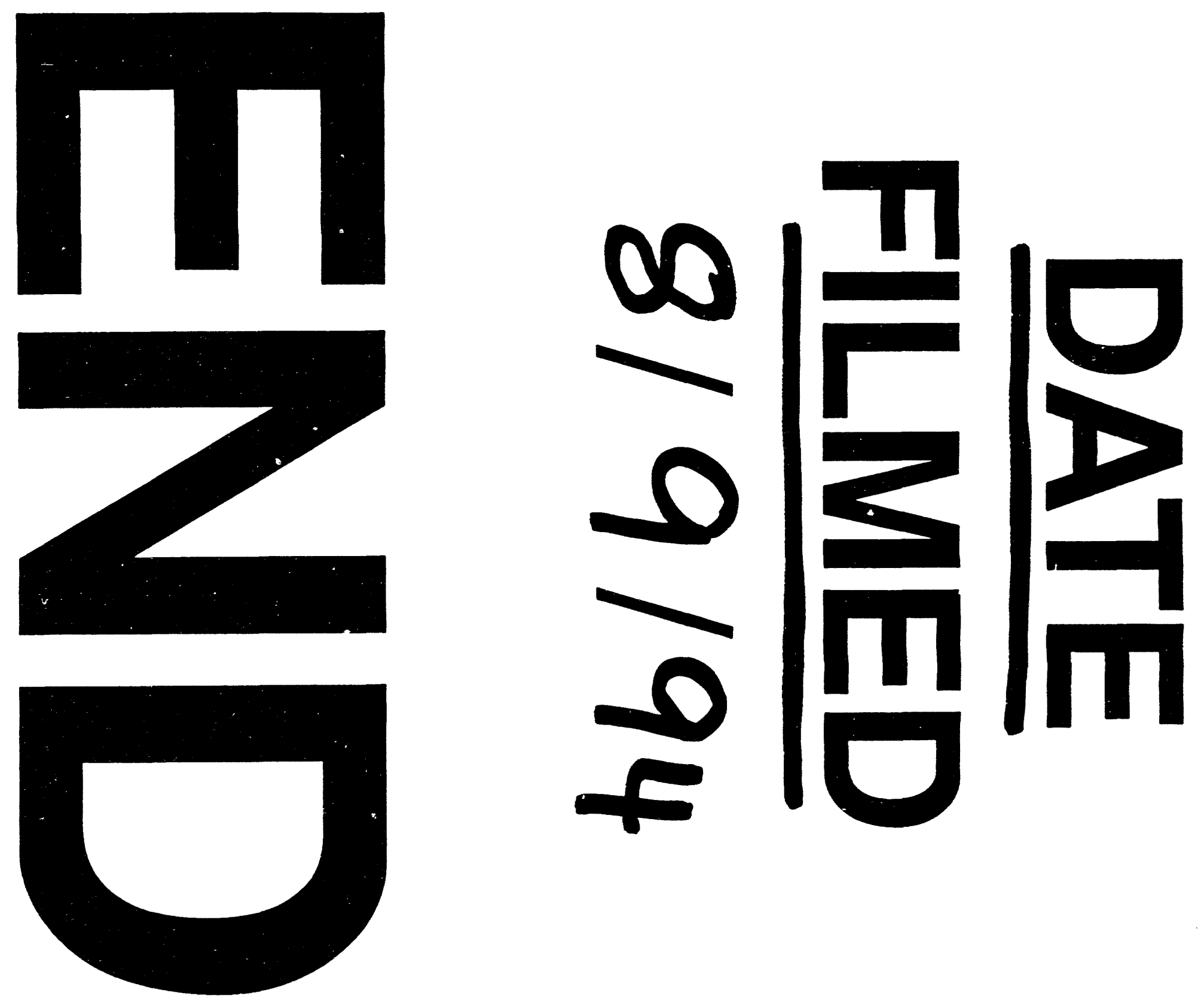